Supporting Information for:

\title{
Allosteric Regulation of Unidirectional Spring-like Motion of Double-Stranded Helicates
}

Yoshimasa Suzuki, Taiki Nakamura, Hiroki Iida, Naoki Ousaka, and Eiji Yashima*

Department of Molecular Design and Engineering, Graduate School of Engineering, Nagoya University, Nagoya 464-8603, Japan

E-mail: yashima@apchem.nagoya-u.ac.jp 


\section{Instruments}

The melting points were measured on a Yanaco MP-500D micromelting point apparatus (Yanako, Kyoto, Japan) and were uncorrected. The IR spectra were recorded on a JASCO FT/IR680 spectrophotometer (JASCO, Tokyo, Japan). The NMR spectra were measured using a Bruker Ascend 500 (Bruker Biospin, Billerica, MA) or a Varian 500AS (Varian, Palo Alto, CA) spectrometer operating at $500 \mathrm{MHz}$ for ${ }^{1} \mathrm{H}$ and $125 \mathrm{MHz}$ for ${ }^{13} \mathrm{C}$ using tetramethylsilane (TMS) or a solvent residual peak as the internal standard. The absorption and CD spectra were measured in a 0.01-, 0.1-, or 1- cm quartz cell using a JASCO V-570 spectrophotometer and a JASCO J-820 spectropolarimeter, respectively. The temperature was controlled with a JASCO PTC-423L apparatus. The fluorescence spectra were measured in a $1-\mathrm{cm}$ quartz cell on a JASCO FP-6500 spectrofluorometer. The electrospray ionization (ESI) mass spectra were recorded using a JEOL JMS-T100CS mass spectrometer (JEOL, Akishima, Japan) or a Bruker Daltonics micrOTOF-Q II spectrometer (Bruker Daltonics, Billerica, MA). The single crystal X-ray diffraction measurements were performed on a Rigaku Saturn $724+$ CCD diffractometer with Mo Ka radiation $(l=0.71075$ $\AA$ ) at $103 \mathrm{~K}$.

\section{Materials}

All starting materials were purchased from commercial suppliers and were used without further purification unless otherwise noted. The spiroborate helicate $\mathbf{1 a},{ }^{\mathrm{S} 1} \mathbf{9},{ }^{\mathrm{S} 2}$ and optically active ammonium salts $(R)-$ and $(S)-5^{+} \cdot \mathrm{I}^{-\mathrm{S} 3}$ and $(R)-$ and $(S)-\mathbf{6}^{+} \cdot \mathrm{I}^{-\mathrm{S} 4}$ were prepared according to the literature. 


\section{Synthesis of Helicates}

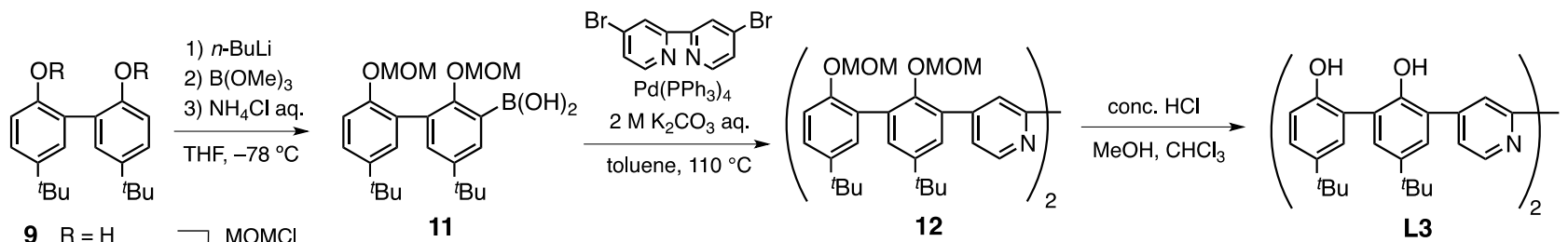

$\begin{array}{rl}9 & \mathrm{R}=\mathrm{H} \\ 10 & \mathrm{R}=\mathrm{MOM}\end{array} \quad \begin{aligned} & \mathrm{MOMCl} \\ & \mathrm{Pr}_{2} \mathrm{NEt}, \mathrm{CH}_{2} \mathrm{Cl}_{2}\end{aligned}$
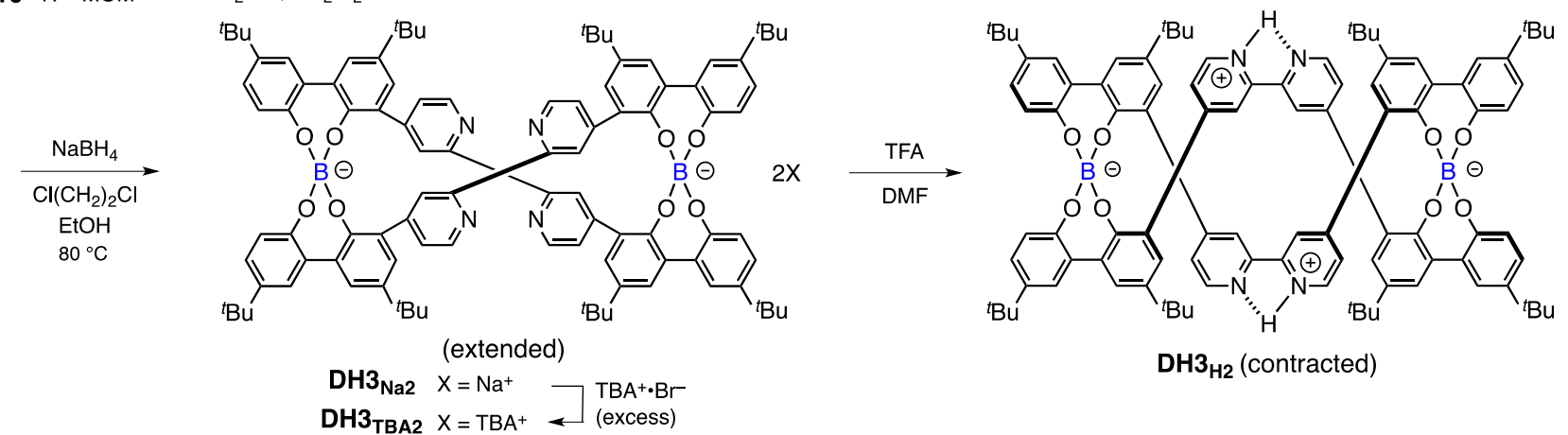

$12 \underset{\mathrm{CH}_{2} \mathrm{Cl}_{2}}{\stackrel{\mathrm{mCPBA}}{\mathrm{CuOH}_{\mathrm{Bu}}}}$
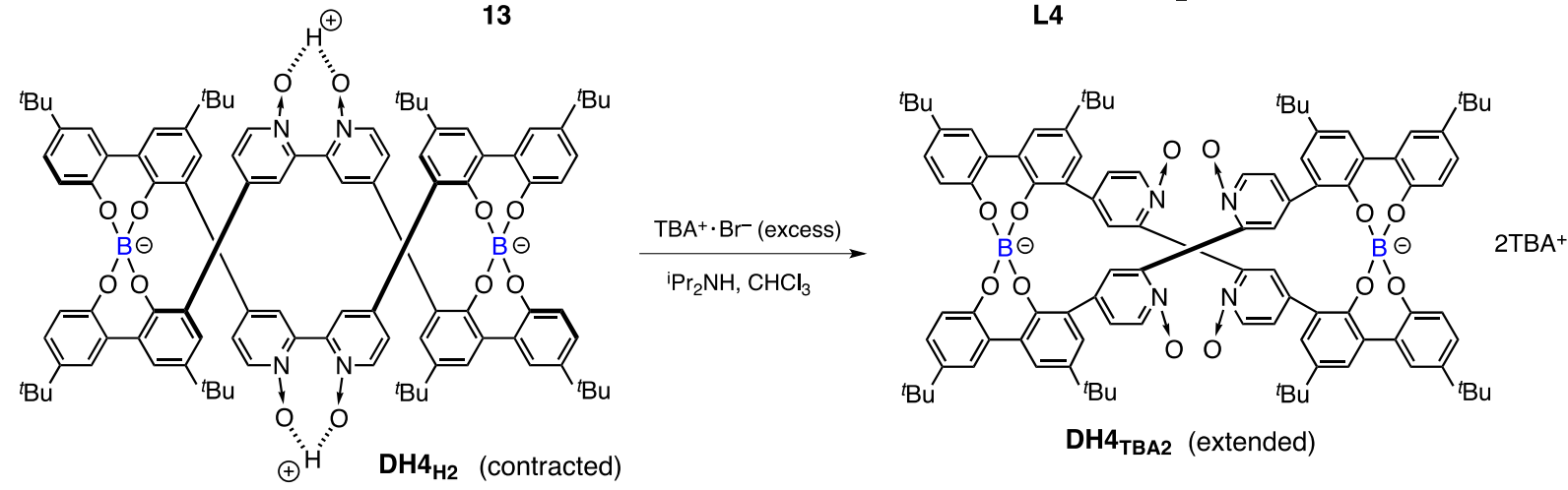

Scheme S1. Syntheses of double-stranded spiroborate helicates DH3 


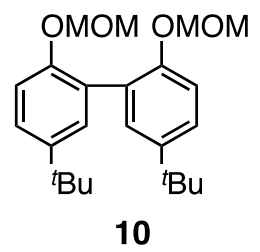

10. To a solution of $9(18.0 \mathrm{~g}, 60.3 \mathrm{mmol})$ in $\mathrm{CHCl}_{3}(120 \mathrm{~mL})$ were added diisopropylethylamine $(61.5 \mathrm{~mL}, 353 \mathrm{mmol})$ and chloromethyl methyl ether (MOMCl, $22.0 \mathrm{~mL}, 290 \mathrm{mmol})$ at $0{ }^{\circ} \mathrm{C}$ under nitrogen, and the reaction mixture was stirred at $0{ }^{\circ} \mathrm{C}$ for $1.5 \mathrm{~h}$. The mixture was then warmed to $50{ }^{\circ} \mathrm{C}$ and stirred overnight. After $\mathrm{H}_{2} \mathrm{O}(500 \mathrm{~mL})$ was added to this, the mixture was extracted with $\mathrm{CHCl}_{3}(3 \times 200 \mathrm{~mL})$. The organic extracts were washed with $\mathrm{H}_{2} \mathrm{O}(2 \times 200 \mathrm{~mL})$ and brine $(200$ $\mathrm{mL}$ ), dried over anhydrous $\mathrm{Na}_{2} \mathrm{SO}_{4}$, filtered, and concentrated under reduced pressure. The crude product was purified by flash column chromatography $\left(\mathrm{SiO}_{2}, n\right.$-hexane/EtOAc $=10 / 0-8 / 2$, v/v $)$ to give 10 (22.9 g, 99\% yield) as a yellow solid. Mp: 135-136 ${ }^{\circ} \mathrm{C}$. IR $\left(\mathrm{KBr}, \mathrm{cm}^{-1}\right): 2962,1492,1198$, 1146, 1083, 811. ${ }^{1} \mathrm{H}$ NMR (500 MHz, $\left.\mathrm{CDCl}_{3}, 25^{\circ} \mathrm{C}\right): \delta$ 7.33-7.29 (m, 4H, ArH), 7.16-7.12 (m, 2H, $\mathrm{ArH}), 5.04\left(\mathrm{~s}, 4 \mathrm{H}, \mathrm{OCH}_{2}\right) 3.33\left(\mathrm{~s}, 6 \mathrm{H}, \mathrm{OCH}_{3}\right), 1.32(\mathrm{~s}, 18 \mathrm{H}, t-\mathrm{Bu}) .{ }^{13} \mathrm{C} \mathrm{NMR}\left(125 \mathrm{MHz}, \mathrm{CDCl}_{3}\right.$, $\left.25{ }^{\circ} \mathrm{C}\right): \delta 152.75,144.44,129.14,128.99,125.37,115.32,95.52,55.96,34.36,31.67 . \mathrm{HRMS}$ (ESI+): $m / z$ calcd for $\mathrm{C}_{24} \mathrm{H}_{34} \mathrm{O}_{4}\left(\mathrm{M}+\mathrm{Na}^{+}\right), 409.2355$; found 409.2363 .

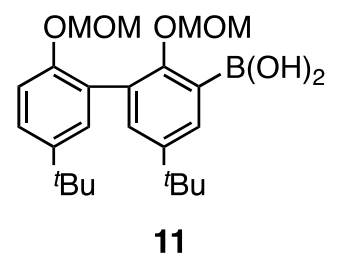

11. To a solution of $\mathbf{1 0}(11.9 \mathrm{~g}, 31.0 \mathrm{mmol})$ and $N, N, N^{\prime}, N^{\prime}$-tetramethylethylenediamine (TMEDA, $5.00 \mathrm{~mL}, 34.1 \mathrm{mmol})$ in THF $(64 \mathrm{~mL})$ was added dropwise $n$-BuLi (1.6 $\mathrm{M}$ in $n$-hexane, $23.0 \mathrm{~mL}$, $36.8 \mathrm{mmol}$ ) at $0{ }^{\circ} \mathrm{C}$ under nitrogen, and the mixture was stirred at room temperature for $1 \mathrm{~h}$. After $\mathrm{B}(\mathrm{OMe})_{3}(17.5 \mathrm{~mL}, 158 \mathrm{mmol})$ was added to this at $0{ }^{\circ} \mathrm{C}$, the mixture was warmed to room temperature, and stirred for $15 \mathrm{~h}$. To this was added a saturated aqueous $\mathrm{NH}_{4} \mathrm{Cl}(150 \mathrm{~mL})$ at $0{ }^{\circ} \mathrm{C}$, and the mixture was stirred at room temperature for $30 \mathrm{~min}$. The mixture was extracted with EtOAc $(3 \times 150 \mathrm{~mL})$, and the organic extracts were washed with brine $(300 \mathrm{~mL})$, dried over anhydrous $\mathrm{MgSO}_{4}$, filtered, and concentrated under reduced pressure. The crude product was purified by flash column chromatography $\left(\mathrm{SiO}_{2}, n\right.$-hexane/EtOAc $\left.=10 / 0-4 / 1, \mathrm{v} / \mathrm{v}\right)$ to give $10.6 \mathrm{~g}$ of 11 as a colorless oil. The purity of $\mathbf{1 1}$ was ca. $90 \%$ on the basis of its ${ }^{1} \mathrm{H}$ NMR spectrum in the presence of pinacol (ca. 10 equiv.), and this was subjected to the next step without further purification. ${ }^{1} \mathrm{H}$ NMR $\left(500 \mathrm{MHz}, \mathrm{CDCl}_{3}\right.$ in the presence of pinacol (ca. 10 equiv.), rt): (the signals for impurities were not 
assigned) $\delta 7.76(\mathrm{~d}, J=2.7 \mathrm{~Hz}, 1 \mathrm{H}, \operatorname{ArH}), 7.43(\mathrm{~d}, J=2.7 \mathrm{~Hz}, 1 \mathrm{H}, \operatorname{ArH}), 7.36(\mathrm{~d}, J=2.6 \mathrm{~Hz}, 1 \mathrm{H}$, ArH), 7.28 (dd, $J=8.7,2.6 \mathrm{~Hz}, 1 \mathrm{H}, \mathrm{ArH}), 7.10$ (d, $J=8.6 \mathrm{~Hz}, 1 \mathrm{H}, \mathrm{ArH}), 5.02$ (s, 2H, OCH$), 4.81$ $\left(\mathrm{s}, 2 \mathrm{H}, \mathrm{OCH}_{2}\right), 3.32\left(\mathrm{~s}, 3 \mathrm{H}, \mathrm{OCH}_{3}\right), 2.78\left(\mathrm{~s}, 2 \mathrm{H}, \mathrm{OCH}_{3}\right), 1.35\left(\mathrm{~s}, 12 \mathrm{H}, \mathrm{C}\left(\mathrm{CH}_{3}\right)_{2}\right), 1.34(\mathrm{~s}, 9 \mathrm{H}, t-\mathrm{Bu})$, $1.31(\mathrm{~s}, 9 \mathrm{H}, t-\mathrm{Bu})$.

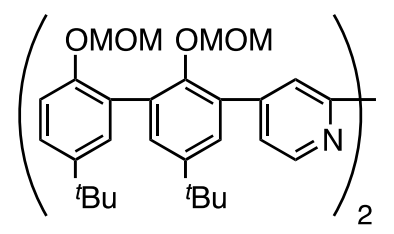

12

12. A mixture of 11 (11.2 g, $26.0 \mathrm{mmol}$ ), 4,4'-dibromo-2,2'-bipyridyl (2.80 g, $8.92 \mathrm{mmol})$, and $\mathrm{Pd}\left(\mathrm{PPh}_{3}\right)_{4}(304 \mathrm{mg}, 0.263 \mathrm{mmol})$ in toluene $(90 \mathrm{~mL})$ and $2 \mathrm{M}$ aqueous $\mathrm{K}_{2} \mathrm{CO}_{3}(16 \mathrm{~mL})$ were stirred at $105{ }^{\circ} \mathrm{C}$ for $25 \mathrm{~h}$ under nitrogen. The mixture was extracted with EtOAc $(3 \times 150 \mathrm{~mL})$, and the organic extracts were washed with $\mathrm{H}_{2} \mathrm{O}(200 \mathrm{~mL})$ and brine $(200 \mathrm{~mL})$, dried over anhydrous $\mathrm{MgSO}_{4}$, filtered, and concentrated under reduced pressure. The crude product was purified by flash column chromatography $\left(\mathrm{NH}-\mathrm{SiO}_{2}, n\right.$-hexane/EtOAc $\left.=10 / 0-10 / 1, \mathrm{v} / \mathrm{v}\right)$ to give $12(7.25 \mathrm{~g}, 90 \%$ yield) as a white solid. Mp: $230-232{ }^{\circ} \mathrm{C}$. IR $\left(\mathrm{KBr}, \mathrm{cm}^{-1}\right): 2961,1587,1500,1234,1156,1077 .{ }^{1} \mathrm{H}$ NMR $\left(500 \mathrm{MHz}, \mathrm{CDCl}_{3}, 25^{\circ} \mathrm{C}\right): \delta 8.71-8.75(\mathrm{~m}, 2 \mathrm{H}, \mathrm{ArH}), 8.66-8.64(\mathrm{~m}, 2 \mathrm{H}, \mathrm{ArH}), 7.63(\mathrm{dd}, J=$ 5.0, 1.7 Hz, 2H, ArH), 7.45-7.41 (m, 6H, ArH), 7.33 (dd, J=8.6, 2.6 Hz, 2H, ArH), 7.15 (d, J=8.7 $\mathrm{Hz}, 2 \mathrm{H}, \mathrm{ArH}), 5.13\left(\mathrm{~s}, 4 \mathrm{H}, \mathrm{OCH}_{2}\right), 4.37\left(\mathrm{~s}, 4 \mathrm{H}, \mathrm{OCH}_{2}\right), 3.41\left(\mathrm{~s}, 6 \mathrm{H}, \mathrm{OCH}_{3}\right), 2.64\left(\mathrm{~s}, 6 \mathrm{H}, \mathrm{OCH}_{3}\right)$, $1.38(\mathrm{~s}, 18 \mathrm{H}, t-\mathrm{Bu}), 1.35(\mathrm{~s}, 18 \mathrm{H}, t-\mathrm{Bu}) .{ }^{13} \mathrm{C} \mathrm{NMR}\left(125 \mathrm{MHz}, \mathrm{CDCl}_{3}, 25{ }^{\circ} \mathrm{C}\right): \delta 156.56,152.62$, $150.31,149.10,148.76,146.95,144.76,133.18,132.75,129.85,129.10,129.03,126.86,125.68$, 124.93, 122.10, 115.28, 99.24, 95.33, 56.51, 56.14, 34.70, 34.41, 31.70, 31.65. HRMS (ESI+): $m / z$ calcd for $\mathrm{C}_{58} \mathrm{H}_{72} \mathrm{~N}_{2} \mathrm{O}_{8}\left(\mathrm{M}+\mathrm{Na}^{+}\right)$, 947.5186; found 947.5148 .

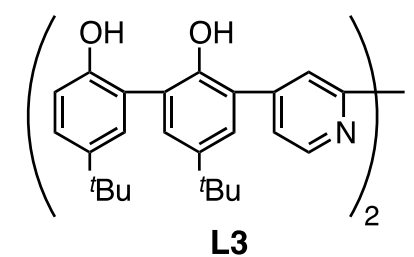

L3. To a solution of $12(100 \mathrm{mg}, 0.108 \mathrm{mmol})$ in $\mathrm{CHCl}_{3}(1.2 \mathrm{~mL})$ and $\mathrm{MeOH}(1.2 \mathrm{~mL})$ was added conc. $\mathrm{HCl}(0.25 \mathrm{~mL})$, and the mixture was stirred at room temperature overnight. The precipitate was collected by filtration, washed with $\mathrm{H}_{2} \mathrm{O}$, and dried in vacuo, giving a yellow solid (73.2 $\mathrm{mg}$ ). The yellow solid $(52.0 \mathrm{mg})$ was then dissolved in DMSO $(2.0 \mathrm{~mL})$, and diisopropylamine (ca. 20 $\mu \mathrm{L}$ ) was added to the solution. After the solvents were evaporated, the residue was washed with 
$\mathrm{H}_{2} \mathrm{O}$ to give $\mathbf{L 3}$ (47.6 mg, 83\% yield) as a red solid. Mp: $191-192{ }^{\circ} \mathrm{C}$. IR $\left(\mathrm{KBr}, \mathrm{cm}^{-1}\right): 2959,1592$, 1466, 1363, 1231, 822. ${ }^{1} \mathrm{H}$ NMR (500 MHz, DMSO-d $\left.6,25{ }^{\circ} \mathrm{C}\right) \delta 9.97$ (br, 2H, OH), 8.74-8.70 (m, 2H, ArH), 8.66-8.63 (m, 2H, ArH), 8.13 (br, 2H, OH), 7.63 (dd, J= 5.0, 1.8 Hz, 2H, ArH), 7.36 (d, $J=2.6 \mathrm{~Hz}, 2 \mathrm{H}, \mathrm{ArH}), 7.27$ (d, $J=2.6 \mathrm{~Hz}, 2 \mathrm{H}, \mathrm{ArH}), 7.25$ (dd, $J=8.4,2.6 \mathrm{~Hz}, 2 \mathrm{H}, \mathrm{ArH}), 7.23$ (d, $J$ $=2.5 \mathrm{~Hz}, 2 \mathrm{H}, \mathrm{ArH}), 6.92(\mathrm{~d}, J=8.4 \mathrm{~Hz}, 2 \mathrm{H}, \mathrm{ArH}), 1.34(\mathrm{~s}, 18 \mathrm{H}, t-\mathrm{Bu}), 1.29(\mathrm{~s}, 18 \mathrm{H}, t-\mathrm{Bu}) ;{ }^{13} \mathrm{C}$ NMR (125 MHz, DMSO-d $\left.d_{6}, 2{ }^{\circ} \mathrm{C}\right): \delta 155.28,151.59,149.10,149.05,148.09,142.41,141.72$, $129.01,128.40,128.14,126.90,125.84,125.60,124.74,124.55,121.24,115.39,33.88,33.75$, 31.41, 31.34. HRMS (ESI-): $m / z$ calcd for $\mathrm{C}_{50} \mathrm{H}_{56} \mathrm{~N}_{2} \mathrm{O}_{4}\left(\mathrm{M}-\mathrm{H}^{+}\right)$, 747.4162; found, 747.4132.

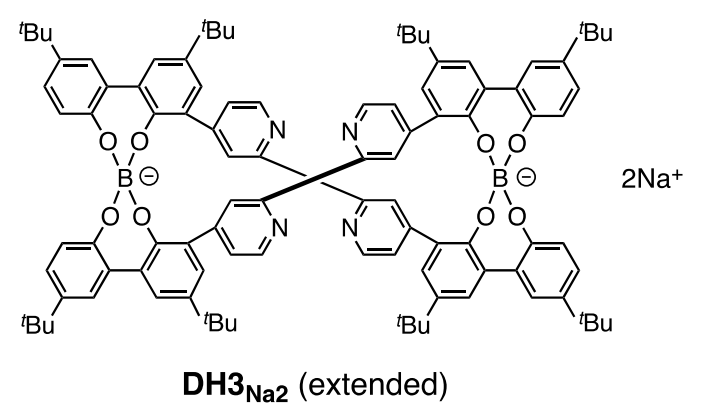

DH3 ${ }_{\mathrm{Na}}$. To a solution of $\mathbf{L 3}(501 \mathrm{mg}, 669 \mu \mathrm{mol})$ in 1,2-dichloroethane (90 mL) was added a solution of $\mathrm{NaBH}_{4}$ in EtOH $(46.7 \mathrm{mM}, 15.0 \mathrm{~mL}, 701 \mu \mathrm{mol})$ under nitrogen. After stirring at $80{ }^{\circ} \mathrm{C}$ for $26 \mathrm{~h}$, the mixture was cooled to ambient temperature to form a precipitate, which was collected by filtration to give $\mathbf{D H 3} \mathbf{N a 2}_{\mathbf{N a}}\left(416 \mathrm{mg}, 80 \%\right.$ yield) as a pale yellow solid. Mp: $>300{ }^{\circ} \mathrm{C}$. IR ( $\mathrm{KBr}$, $\left.\mathrm{cm}^{-1}\right): 2960,1606,1499,1460,1267,1235,1026 .{ }^{1} \mathrm{H}$ NMR $\left(500 \mathrm{MHz}, \mathrm{DMSO}-d_{6}, 25{ }^{\circ} \mathrm{C}\right) \delta 7.96(\mathrm{br}$ s, 4H, ArH), $7.91(\mathrm{dd}, J=5.2,1.8 \mathrm{~Hz}, 4 \mathrm{H}, \mathrm{ArH}), 7.81(\mathrm{~d}, J=5.2 \mathrm{~Hz}, 4 \mathrm{H}, \mathrm{ArH}), 7.55$ (d, $J=2.4 \mathrm{~Hz}$, 4H, ArH), 7.43 (d, $J=2.4 \mathrm{~Hz}, 4 \mathrm{H}, \mathrm{ArH}), 7.32$ (d, $J=2.4 \mathrm{~Hz}, 4 \mathrm{H}, \mathrm{ArH}), 7.29$ (dd, $J=8.3,2.5 \mathrm{~Hz}$, $4 \mathrm{H}, \mathrm{ArH}), 6.78(\mathrm{~d}, J=8.3 \mathrm{~Hz}, 4 \mathrm{H}, \mathrm{ArH}), 1.52$ (s, $36 \mathrm{H}, t-\mathrm{Bu}), 1.38(\mathrm{~s}, 36 \mathrm{H}, t-\mathrm{Bu}) ;{ }^{13} \mathrm{C}$ NMR $(125$ MHz, DMSO- $\left.d_{6}, 25^{\circ} \mathrm{C}\right): \delta 155.08,154.59,152.87,147.36,146.25,141.96,140.73,131.49,131.24$, 126.95, 126.71, 125.70, 124.47, 124.39, 121.33, 118.70, 33.95, 33.88, 31.69, 31.64. HRMS (ESI-): $m / z$ calcd for $\mathrm{C}_{100} \mathrm{H}_{104} \mathrm{~B}_{2} \mathrm{~N}_{4} \mathrm{O}_{8} \mathrm{Na}_{2}\left(\mathrm{M}-2 \mathrm{Na}^{+}+\mathrm{H}^{+}\right)$, 1511.8146; found, 1511.8112 .

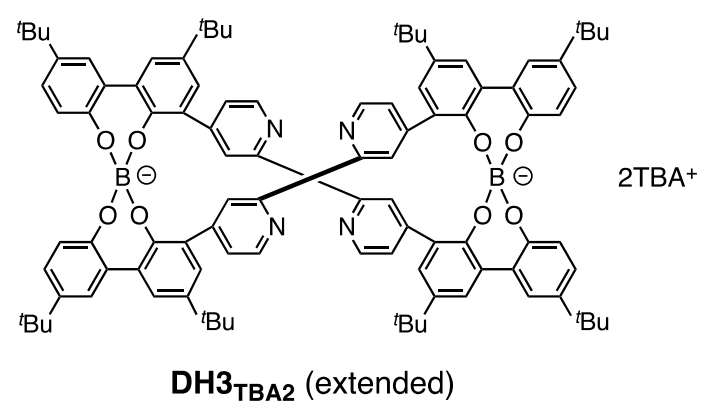




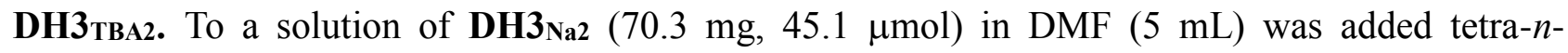
butylammonium bromide $\left(\mathrm{TBA}^{+} \cdot \mathrm{Br}^{-}, 1.46 \mathrm{~g}, 4.53 \mathrm{mmol}\right)$, and the DMF solution was poured into a large amount of diethyl ether. The resulting precipitate was collected, washed with $\mathrm{H}_{2} \mathrm{O}$, and dried in vacuo to afford DH3 ${ }_{\text {TBA2 }}\left(75.0 \mathrm{mg}, 83 \%\right.$ yield) as a pale yellow solid. $\mathrm{Mp}:>300{ }^{\circ} \mathrm{C}$. IR $(\mathrm{KBr}$, $\mathrm{cm}^{-1}$ ): 2961, 1586, 1499, 1460, 1266. ${ }^{1} \mathrm{H}$ NMR (500 MHz, DMSO-d $\left.6,25{ }^{\circ} \mathrm{C}\right) \delta 7.97$ (br s, 4H, ArH), 7.91 (dd, $J=5.3,1.8 \mathrm{~Hz}, 4 \mathrm{H}, \operatorname{ArH}), 7.81$ (d, $J=5.2 \mathrm{~Hz}, 4 \mathrm{H}, \mathrm{ArH}), 7.55$ (d, $J=2.4 \mathrm{~Hz}, 4 \mathrm{H}$, ArH), 7.42 (d, $J=2.4 \mathrm{~Hz}, 4 \mathrm{H}, \mathrm{ArH}), 7.32$ (d, $J=2.4 \mathrm{~Hz}, 4 \mathrm{H}, \mathrm{ArH}), 7.30$ (dd, $J=8.3,2.5 \mathrm{~Hz}, 4 \mathrm{H}$, $\mathrm{ArH}), 6.78$ (d, $J=8.3 \mathrm{~Hz}, 4 \mathrm{H}, \mathrm{ArH}), 3.15$ (br t, $\left.J=8.5 \mathrm{~Hz}, 16 \mathrm{H}, \mathrm{NCH}_{2}\right), 1.56\left(\mathrm{~m}, 16 \mathrm{H}, \mathrm{NCH}_{2} \mathrm{CH}_{2}\right)$ $1.52(\mathrm{~s}, 36 \mathrm{H}, t-\mathrm{Bu}), 1.38(\mathrm{~s}, 36 \mathrm{H}, t-\mathrm{Bu}), 1.30\left(\mathrm{~m}, 16 \mathrm{H}, \mathrm{CH}_{2} \mathrm{CH}_{3}\right), 0.93\left(\mathrm{t}, 24 \mathrm{H}, \mathrm{CH}_{2} \mathrm{CH}_{3}\right) ;{ }^{13} \mathrm{C}$ NMR (125 MHz, DMSO-d $\left.d_{6}, 2{ }^{\circ} \mathrm{C}\right): \delta$ 155.08, 154.60, 152.88, 147.37, 146.24, 141.96, 140.72, 131.50, 131.26, 126.95, 126.69, 125.70, 124.47, 124.39, 121.33, 118.70, 57.51, 33.94, 33.88, 31.68, 31.64, 23.04, 19.19, 13.49. HRMS (ESI-): $m / z$ calcd for $\mathrm{C}_{130} \mathrm{H}_{172} \mathrm{~B}_{2} \mathrm{~N}_{6} \mathrm{O}_{8}\left(\mathrm{M}-2 \mathrm{TBA}^{+}+\mathrm{H}^{+}\right)$, 1511.8146; found, 1511.8169 .

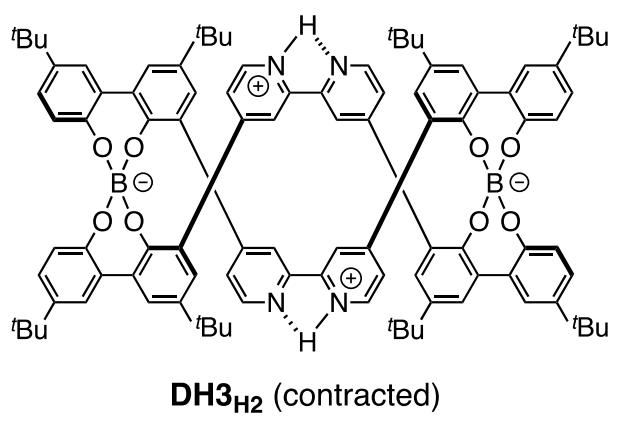

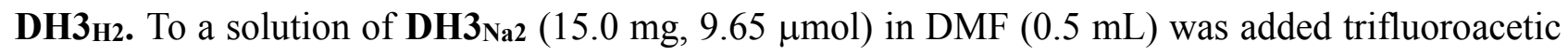
acid (TFA, $2.21 \mu \mathrm{L}, 28.9 \mu \mathrm{mol}$ ), and the DMF solution was poured into a large amount of diethyl ether. The resulting precipitate was collected and dried in vacuo to afford $\mathbf{D H} \mathbf{3}_{\mathbf{H} 2}(11.1 \mathrm{mg}, 76 \%$ yield) as a yellow solid. Mp: $>300{ }^{\circ} \mathrm{C}$. IR $\left(\mathrm{KBr}, \mathrm{cm}^{-1}\right): 2961,1629,1590,1498,1267,997 .{ }^{1} \mathrm{H}$ NMR $\left(500 \mathrm{MHz}, \mathrm{DMSO}-d_{6}, 25^{\circ} \mathrm{C}\right) \delta 15.12$ (bs, 2H, NH), 8.79 (d, $\left.J=5.5 \mathrm{~Hz}, 4 \mathrm{H}, \mathrm{ArH}\right), 8.54$ (s, 4H, ArH), 8.05 (br s, 4H, ArH), 7.40 (d, $J=2.5 \mathrm{~Hz}, 4 \mathrm{H}, \mathrm{ArH}), 7.04$ (d, $J=2.5 \mathrm{~Hz}, 4 \mathrm{H}, \mathrm{ArH}), 6.67$ $(\mathrm{d}, J=2.5 \mathrm{~Hz}, 4 \mathrm{H}, \mathrm{ArH}), 6.26(\mathrm{dd}, J=8.5,2.5 \mathrm{~Hz}, 4 \mathrm{H}, \mathrm{ArH}), 5.25$ (d, $J=8.5 \mathrm{~Hz}, 4 \mathrm{H}, \mathrm{ArH}), 1.30$ (s, $36 \mathrm{H}, t$-Bu), 0.93, (s, $36 \mathrm{H}, t$-Bu); ${ }^{13} \mathrm{C}$ NMR (125 MHz, DMSO- $\left.d_{6}, 25{ }^{\circ} \mathrm{C}\right)$ : (DH3 TBA2 with 2 equiv of TFA was used for the ${ }^{13} \mathrm{C}$ NMR measurement because of the low solubility of $\left.\mathbf{D H 3} \mathbf{H 2}\right) \delta 153.13$, $153.05,145.98,141.69,140.23,132.55,129.64,128.02,126.42,125.14,124.68,124.20,124.16$, 122.83, 118.88, 57.50, 33.74, 33.12, 31.23, 31.09, 23.04, 19.20, 13.48. HRMS (ESI-): $m / z$ calcd for $\mathrm{C}_{100} \mathrm{H}_{106} \mathrm{~B}_{2} \mathrm{~N}_{4} \mathrm{O}_{8}\left(\mathrm{M}-\mathrm{H}^{+}\right), 1511.8146$; found, 1511.8121 . 
Optical Resolution of $( \pm)-\mathbf{D H} 3_{\mathrm{Na}}$. The optical resolution of the boron helicate $( \pm)-\mathbf{D H} 3_{\mathrm{Na}}$ was carried out by diastereomeric salt formation through the cation exchange as shown in Figure 3. A typical experimental procedure is described below.

To a solution of $( \pm)-\mathbf{D H 3}_{\mathrm{Na} 2}(300 \mathrm{mg}, 193 \mu \mathrm{mol})$ in DMF $(42 \mathrm{~mL})$ was added a 10-fold molar excess of $(S)-5^{+} \cdot \mathrm{I}^{-}(495 \mathrm{mg}, 1.93 \mathrm{mmol})$, and the mixture was allowed to stand under a saturated acetone vapor at room temperature. The resulting colorless crystals (206 mg) were collected by filtration. This procedure was repeated to give the diastereomeric salt $(+)-\mathbf{D H} \mathbf{3}_{[(S)-5]_{2}}$ of $>99 \%$ diastereomeric excess $(\mathrm{de})(147 \mathrm{mg})$ as a colorless crystal. The prefixes $(+)$ and $(-)$ denote the signs of the Cotton effect at $336 \mathrm{~nm}$. The optically active cation $(S)-\mathbf{5}^{+}$of $(+)-\mathbf{D H} \mathbf{3}_{[(S)-5] 2}$ was then exchanged with an achiral tetra- $n$-butylammonium cation $\left(\mathrm{TBA}^{+}\right)$. The $(+)-\mathbf{D H} \mathbf{3}_{[(S)-5] 2}(147 \mathrm{mg})$ was dissolved in DMF $(30 \mathrm{~mL})$, and to this was added $\mathrm{TBA}^{+} \cdot \mathrm{Br}^{-}(2.70 \mathrm{~g}, 8.38 \mathrm{mmol})$. The DMF solution was poured into a large amount of diethyl ether, and the resulting precipitate was collected, washed with $\mathrm{H}_{2} \mathrm{O}$, and dried in vacuo to afford (+)-DH3 твA2 (153 mg, 40\% yield based on ( \pm )$\mathbf{D H 3}_{\mathrm{Na} 2}$ ) as a pale yellow solid. The enantiomeric excess (ee) of (+)-DH3 $\mathbf{T B A}_{\mathbf{2}}$ was estimated to be $>99 \%$ by its ${ }^{1} \mathrm{H}$ NMR spectrum in the presence of $(S, S)-7^{+} \cdot \mathrm{Br}^{-}$as a chiral shift reagent (Figure S26). The corresponding enantiomer (-)-DH3 TвA2 of $>99 \%$ ee was also prepared in the same way in $20 \%$ yield (based on $( \pm)-\mathbf{D H} \mathbf{3}_{\mathrm{Na}}$ ) using $(R)-\mathbf{5}^{+} \cdot \mathrm{I}^{-}$as the optically active ammonium salt.

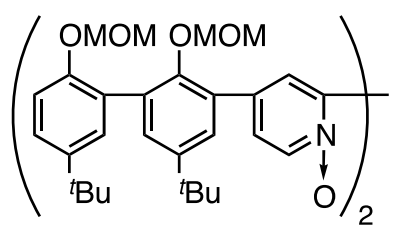

13

13. To a solution of $12(150 \mathrm{mg}, 0.163 \mathrm{mmol})$ in $\mathrm{CH}_{2} \mathrm{Cl}_{2}(1.7 \mathrm{~mL})$ was added $m$-chloroperbenzoic acid ( $m$ CPBA, $120 \mathrm{mg}, 0.489 \mathrm{mmol}$ ) under nitrogen, and the reaction mixture was stirred at room temperature for $16.5 \mathrm{~h}$. After $\mathrm{H}_{2} \mathrm{O}(2.2 \mathrm{~mL})$ was added to this, the mixture was extracted with $\mathrm{CHCl}_{3}(3 \times 8 \mathrm{~mL})$. The organic extracts were washed with saturated aqueous $\mathrm{NaHCO}_{3}(10 \mathrm{~mL})$ and brine $(10 \mathrm{~mL})$, dried over anhydrous $\mathrm{Na}_{2} \mathrm{SO}_{4}$, filtered, and concentrated under reduced pressure. The crude product was purified by flash column chromatography $\left(\mathrm{NH}-\mathrm{SiO}_{2}, \mathrm{CHCl}_{3}\right)$ to give $\mathbf{1 3}$ (137 mg, 88\% yield) as a white solid. Mp: $142-145{ }^{\circ} \mathrm{C}$. IR $\left(\mathrm{KBr}, \mathrm{cm}^{-1}\right): 2960,1474,1263,1155$, 1078. ${ }^{1} \mathrm{H} \mathrm{NMR}\left(500 \mathrm{MHz}, \mathrm{CDCl}_{3}, 25{ }^{\circ} \mathrm{C}\right): \delta 8.38(\mathrm{~d}, J=6.9 \mathrm{~Hz}, 2 \mathrm{H}, \mathrm{ArH}), 7.88(\mathrm{~d}, J=2.6 \mathrm{~Hz}, 2 \mathrm{H}$, ArH), 7.70 (dd, $J=6.9,2.6 \mathrm{~Hz}, 2 \mathrm{H}, \operatorname{ArH}), 7.41$ (d, $J=2.6 \mathrm{~Hz}, 2 \mathrm{H}, \operatorname{ArH}), 7.37$ (d, $J=2.3 \mathrm{~Hz}, 2 \mathrm{H}$, ArH), 7.37 (d, $J=2.5 \mathrm{~Hz}, 2 \mathrm{H}, \operatorname{ArH}), 7.33$ (dd, $J=8.7,2.6 \mathrm{~Hz}, 2 \mathrm{H}, \operatorname{ArH}), 7.13$ (d, $J=8.7 \mathrm{~Hz}, 2 \mathrm{H}$, $\mathrm{ArH}), 5.08\left(\mathrm{~s}, 4 \mathrm{H}, \mathrm{OCH}_{2}\right), 4.44\left(\mathrm{~s}, 4 \mathrm{H}, \mathrm{OCH}_{2}\right), 3.33\left(\mathrm{~s}, 6 \mathrm{H}, \mathrm{OCH}_{3}\right), 2.81\left(\mathrm{~s}, 6 \mathrm{H}, \mathrm{OCH}_{3}\right), 1.35(\mathrm{~s}, 18$ 
$\mathrm{H}, t$-Bu), $1.32\left(\mathrm{~s}, 18 \mathrm{H}, t\right.$-Bu). $\left.{ }^{13} \mathrm{C} \mathrm{NMR} \mathrm{(125} \mathrm{MHz,} \mathrm{CDCl}_{3}, 25{ }^{\circ} \mathrm{C}\right): \delta 152.47,150.30,147.25$, $144.89,142.41,139.51,136.96,133.30,130.60,130.53,129.00,128.87,128.60,127.47,126.20$, 125.90, 115.44, 99.43, 95.37, 56.94, 56.07, 34.70, 34.40, 31.67, 31.58. HRMS (ESI+): $m / z$ calcd for $\mathrm{C}_{58} \mathrm{H}_{72} \mathrm{~N}_{2} \mathrm{O}_{10}\left(\mathrm{M}+\mathrm{Na}^{+}\right), 979.5085$; found 979.5095 .

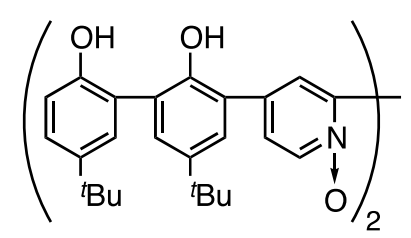

L4

L4. To a solution of $13(220 \mathrm{mg}, 0.230 \mathrm{mmol})$ in $\mathrm{CHCl}_{3}(2.5 \mathrm{~mL})$ and $\mathrm{MeOH}(2.5 \mathrm{~mL})$ was added conc. $\mathrm{HCl}(0.5 \mathrm{~mL})$, and the mixture was stirred at room temperature overnight. The precipitate was collected by filtration, washed with $\mathrm{H}_{2} \mathrm{O}$ to give $\mathbf{L 4}$ (160 mg, 89\% yield) as a pale yellow solid. Mp: $245{ }^{\circ} \mathrm{C}$ (dec.). IR (KBr, cm ${ }^{-1}$ ): 3422, 2960, 1508, 1474, 1233. ${ }^{1} \mathrm{H}$ NMR (500 MHz, DMSO-d6, $\left.25^{\circ} \mathrm{C}\right) \delta 9.92(\mathrm{br}, 2 \mathrm{H}, \mathrm{OH}), 8.46(\mathrm{~d}, J=6.9 \mathrm{~Hz}, 2 \mathrm{H}, \mathrm{ArH}), 8.23$ (bs, 2H, OH), 8.01 (d, $J=2.7 \mathrm{~Hz}$, 2H, ArH), 7.85 (dd, $J=6.9,2.7 \mathrm{~Hz}, 2 \mathrm{H}, \mathrm{ArH}), 7.41(\mathrm{~d}, J=2.6 \mathrm{~Hz}, 2 \mathrm{H}, \mathrm{ArH}), 7.25$ (dd, $J=8.6,2.5$ $\mathrm{Hz}, 2 \mathrm{H}, \mathrm{ArH}), 7.24$ (d, J=2.5 Hz, 2H, ArH), 7.20 (d, J=2.5 Hz, 2H, ArH), 6.90 (d, J=8.5 Hz, 2H, $\mathrm{ArH}), 1.31(\mathrm{~s}, 18 \mathrm{H}, t-\mathrm{Bu}), 1.27(\mathrm{~s}, 18 \mathrm{H}, t-\mathrm{Bu}) .{ }^{13} \mathrm{C} \mathrm{NMR}\left(125 \mathrm{MHz}, \mathrm{CDCl}_{3}, 25{ }^{\circ} \mathrm{C}\right): \delta 151.60$, $149.19,142.71,141.71,141.40,140.48,138.99$, 129.90, 129.62, 128.33, 128.31, 128.26, 126.04, 125.70, 124.44, 124.35, 115.47. HRMS (ESI-): $m / z$ calcd for $\mathrm{C}_{50} \mathrm{H}_{56} \mathrm{~N}_{2} \mathrm{O}_{6}\left(\mathrm{M}-\mathrm{H}^{+}\right), 779.4060$; found 779.4060 .

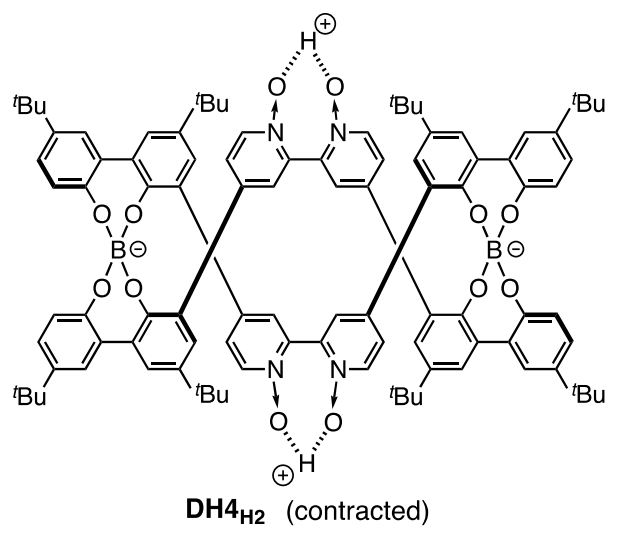

DH4 H2. To a suspension of $\mathbf{L 4}(10.0 \mathrm{mg}, 12.8 \mu \mathrm{mol})$ in $\mathrm{CH}_{3} \mathrm{CN}(25.6 \mathrm{~mL})$ was added $\mathrm{Na}_{2} \mathrm{~B}_{4} \mathrm{O}_{7}$ $(2.58 \mathrm{mg}, 12.8 \mu \mathrm{mol})$, and the mixture was stirred at $70^{\circ} \mathrm{C}$ for $10 \mathrm{~h}$. After the solvent was removed by evaporation, the residue was washed with $n$-hexane and $\mathrm{H}_{2} \mathrm{O}$ to give $\mathbf{D H} \mathbf{H}_{\mathbf{H} 2}(9.37 \mathrm{mg}, 90 \%$ yield) as a yellow solid. $\mathrm{Mp}:>300{ }^{\circ} \mathrm{C}$. IR $\left(\mathrm{KBr}, \mathrm{cm}^{-1}\right): 2960,1474,1238,989 .{ }^{1} \mathrm{H}$ NMR $(500 \mathrm{MHz}$, $\left.\mathrm{CD}_{3} \mathrm{CN}, 25{ }^{\circ} \mathrm{C}\right): \delta 17.25$ (bs, $\left.2 \mathrm{H}, \mathrm{NOH}\right), 8.80(\mathrm{~d}, J=6.8 \mathrm{~Hz}, 4 \mathrm{H}, \mathrm{ArH}), 8.13(\mathrm{dd}, J=6.7,2.2 \mathrm{~Hz}$, 4H, ArH), 7.94 (d, $J=2.0 \mathrm{~Hz}, 4 \mathrm{H}, \mathrm{ArH}), 7.34$ (d, $J=2.6 \mathrm{~Hz}, 4 \mathrm{H}, \mathrm{ArH}), 7.07$ (d, $J=2.6 \mathrm{~Hz}, 4 \mathrm{H}$, 
ArH), 6.89 (d, $J=2.5 \mathrm{~Hz}, 4 \mathrm{H}, \operatorname{ArH}), 6.67$ (dd, $J=8.2,2.5 \mathrm{~Hz}, 4 \mathrm{H}, \operatorname{ArH}), 5.36$ (d, $J=5.36 \mathrm{~Hz}, 4 \mathrm{H}$, $\mathrm{ArH}), 1.32(\mathrm{~s}, 36 \mathrm{H}, t-\mathrm{Bu}), 0.97(\mathrm{~s}, 36 \mathrm{H}, t-\mathrm{Bu}) .{ }^{13} \mathrm{C} \mathrm{NMR}\left(125 \mathrm{MHz}, \mathrm{CDCl}_{3}, 25{ }^{\circ} \mathrm{C}\right): \delta 154.72$, $153.63,151.53,143.77,142.60,140.89,140.50,133.41,132.42,131.25,130.93,130.86,127.66$, 126.74, 126.46, 124.70, 118.93, 118.32, 34.76, 34.43, 31.64, 31.51. HRMS (ESI-): $\mathrm{m} / \mathrm{z}$ calcd for $\mathrm{C}_{100} \mathrm{H}_{106} \mathrm{O}_{12} \mathrm{~N}_{4} \mathrm{~B}_{2}\left(\mathrm{M}-\mathrm{H}^{+}\right), 1575.7943$; found 1575.7928 .

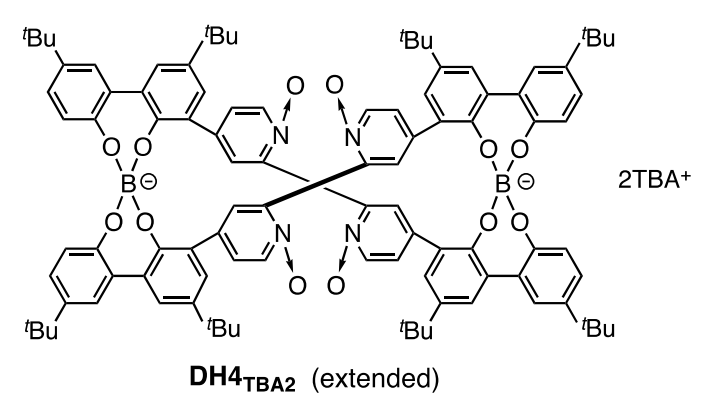

DH4tвa2. To a solution of $\mathbf{D H 4}_{\mathbf{H} 2}(61.8 \mathrm{mg}, 38.1 \mu \mathrm{mol})$ and tetra- $n$-butylammonium bromide $\left(\mathrm{TBA}^{+} \cdot \mathrm{Br}^{-}, 1.21 \mathrm{~g}, 3.81 \mathrm{mmol}\right)$ in $\mathrm{CHCl}_{3}(20 \mathrm{~mL})$ was added diisopropylamine $(16.0 \mu \mathrm{L}, 114$ $\mu \mathrm{mol})$. After the mixture was concentrated to ca. one-tenth of its original volume by evaporation, the residue was poured into a large amount of diethyl ether. The precipitate was collected by centrifugation, washed with diethyl ether $(25 \mathrm{~mL}), \mathrm{H}_{2} \mathrm{O}(25 \mathrm{~mL})$, and $\mathrm{CHCl}_{3}(4 \mathrm{~mL})$, and dried in vacuo at room temperature to give DH4 (dec.). IR ( $\left.\mathrm{KBr}, \mathrm{cm}^{-1}\right): 2960,1469,1267,978 .{ }^{1} \mathrm{H} \mathrm{NMR}\left(500 \mathrm{MHz}, \mathrm{CD}_{3} \mathrm{CN}, 25{ }^{\circ} \mathrm{C}\right): \delta 8.26(\mathrm{dd}, J=$ 7.3, $2.5 \mathrm{~Hz}, 4 \mathrm{H}, \mathrm{ArH}), 7.52$ (d, $J=2.4 \mathrm{~Hz}, 4 \mathrm{H}, \mathrm{ArH}), 7.37$ (d, $J=7.1 \mathrm{~Hz}, 4 \mathrm{H}, \mathrm{ArH}), 7.35$ (d, $J=2.6$ Hz, 4H, ArH), 7.29 (dd, $J=8.4,2.5 \mathrm{~Hz}, 4 \mathrm{H}, \mathrm{ArH}), 7.23$ (d, $J=2.6 \mathrm{~Hz}, 4 \mathrm{H}, \mathrm{ArH}), 7.20$ (d, $J=2.4$ $\mathrm{Hz}, 4 \mathrm{H}, \mathrm{ArH}), 6.82$ (d, $J=8.4 \mathrm{~Hz}, 4 \mathrm{H}, \mathrm{ArH}), 3.10-3.01$ (m, 16H, $\left.\mathrm{NCH}_{2}\right), 1.63-1.53\left(\mathrm{~m}, 16 \mathrm{H}, \mathrm{CH}_{2}\right)$, $1.43(\mathrm{~s}, 36 \mathrm{H}, t-\mathrm{Bu}), 1.39(\mathrm{~s}, 36 \mathrm{H}, t-\mathrm{Bu}), 1.33\left(\mathrm{sext}, J=7.5 \mathrm{~Hz}, 16 \mathrm{H}, \mathrm{CH}_{2}\right), 0.95(\mathrm{t}, J=7.5 \mathrm{~Hz}, 24 \mathrm{H}$, $\left.\mathrm{CH}_{3}\right) .{ }^{13} \mathrm{C} \mathrm{NMR}\left(125 \mathrm{MHz}, \mathrm{CDCl}_{3}, 25{ }^{\circ} \mathrm{C}\right): \delta 155.84,154.04,144.05,143.48,142.06,137.70$, $137.35,134.11,131.55,128.48,127.83,127.40,127.09,126.53,126.14,123.69,122.02,118.31$, 59.31, 35.13, 34.80, 32.16, 32.02, 24.28, 20.30, 13.78. HRMS (ESI-): $\mathrm{m} / z$ calcd for $\mathrm{C}_{130} \mathrm{H}_{172} \mathrm{~B}_{2} \mathrm{~N}_{6} \mathrm{O}_{12}\left(\mathrm{M}-2 \mathrm{TBA}^{+}+\mathrm{H}^{+}\right), 1575.7943$; found 1575.8018 .

Optical Resolution of $( \pm)-\mathrm{DH}_{\mathrm{H} 2}$ by Diastereomeric Salt Formation. The optical resolution of the boron helicate $( \pm)-\mathbf{D H} \mathbf{H}_{\mathbf{H}}$ was also carried out by diastereomeric salt formation through the cation exchange as shown in Figure 3. A typical experimental procedure is described below.

To a solution of $( \pm)-\mathbf{D H} 4 \mathrm{H}_{2}(147 \mathrm{mg}, 90.7 \mu \mathrm{mol})$ in $\mathrm{CH}_{2} \mathrm{Cl}_{2}(40 \mathrm{~mL})$ was added diisopropylamine $(39.0 \mu \mathrm{L}, 278 \mu \mathrm{mol})$ and a 10 -fold molar excess of $(S)-\mathbf{6}^{+} \cdot \mathrm{I}^{-}(263 \mathrm{mg}, 903 \mu \mathrm{mol})$, and the mixture was allowed to stand at room temperature for $60 \mathrm{~h}$. The resulting pale yellow 
precipitations were collected by filtration, washed with a large amount of $\mathrm{CH}_{2} \mathrm{Cl}_{2}$, and dried in vacuo to give the diastereomeric salt $(-)-\mathbf{D H} \mathbf{4}_{[(S)-6]_{2}}$ of $>99 \%$ de. The prefixes $(+)$ and $(-)$ denote the signs of the Cotton effect at $377 \mathrm{~nm}$. The optically active cation $(S)-6^{+}$of $(-)-\mathbf{D H} \mathbf{4}_{[(S)-6] 2}$ was then exchanged with $\mathrm{TBA}^{+}$. The (-)-DH4 $4_{[(S)-6]_{2}}$ was dissolved in $\mathrm{CH}_{2} \mathrm{Cl}_{2}$, and to this was added a large excess of $\mathrm{TBA}^{+} \cdot \mathrm{Br}^{-}(500 \mathrm{mg}, 1.55 \mathrm{mmol})$. After evaporation of the solvent, the resulting residue was washed with $\mathrm{H}_{2} \mathrm{O}(50 \mathrm{~mL})$ and a large amount of $\mathrm{CHCl}_{3}$ to give (-)-DH4 TBA2 $(61.9 \mathrm{mg}, 33 \%$ yield based on $( \pm)$-DH4 $\left.\mathbf{H}_{2}\right)$. The ee value of $(-)$-DH4 TBA2 was estimated to be $>99 \%$ by its ${ }^{1} \mathrm{H}$ NMR spectrum in the presence of $\mathbf{8}^{+} \cdot \mathrm{Br}^{-}$as a chiral shift reagent (Figure S27). The corresponding enantiomer $(+)$-DH4 TBA2 of $>99 \%$ ee was also prepared in the same way in $30 \%$ yield (based on $\left.( \pm)-\mathbf{D H} 4_{\mathbf{H} 2}\right)$ using $(R)-\mathbf{6}^{+} \cdot \mathrm{I}^{-}$as the optically active ammonium salt.

Optical Resolution of $( \pm)-D H 4 H_{2}$ by Chiral HPLC. The optical resolution of the boron helicate $( \pm)-\mathbf{D H} 4_{\mathrm{H} 2}$ was performed by chiral HPLC using a chiral column (CHIRALPAK IA, Daicel, Co., Ltd.) with $n$-hexane $/ \mathrm{CH}_{2} \mathrm{Cl}_{2} / \mathrm{CH}_{3} \mathrm{CN}(60: 40: 5, \mathrm{v} / \mathrm{v})$ containing $\mathrm{TBA}^{+} \cdot \mathrm{Br}^{-}(0.5 \mathrm{mg} / \mathrm{mL})$ as the eluent, giving the corresponding optically pure extended helicates complexed with $\mathrm{TBA}^{+}$cations $((+)$DH4твA2 and (-)-DH4твA2) that formed during the chromatographic enantioseparation through cation exchange (Figure S28). 


\section{X-ray Crystallographic Data}

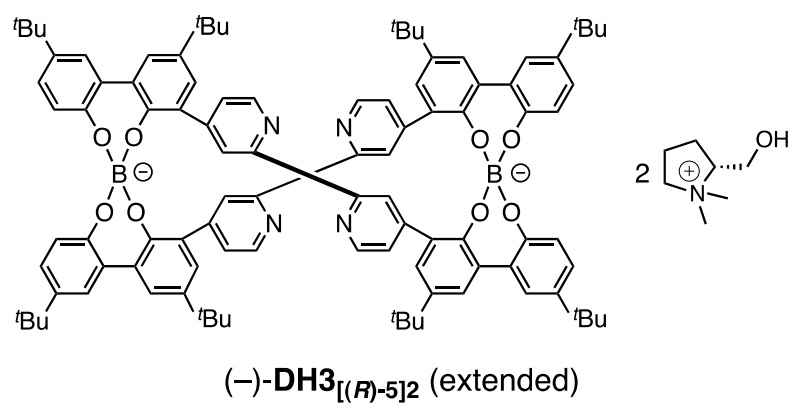

\section{Crystallographic Data of (-)-DH3 $3_{[(R)-5] 2}$}

X-ray diffraction data set for $(-)-\mathbf{D H} 3_{[(R)-5] 2}$ was collected on a Rigaku Saturn $724+$ CCD diffractometer with Mo K $\alpha$ radiation $(\lambda=0.71075 \AA)$ at $103 \mathrm{~K}$. Single crystals of $(-)-\mathbf{D H} \mathbf{3}_{[(\boldsymbol{R})-5] 2}$ $\left[\mathrm{C}_{122} \mathrm{H}_{156} \mathrm{~B}_{2} \mathrm{~N}_{6} \mathrm{O}_{12}, \mathrm{MW}=1920.15\right]$ suitable for $\mathrm{X}$-ray analysis were obtained by the slow diffusion of diethyl ether into a DMF solution of (-)-DH3 $3_{[(R)-5] 2}$, and a single colorless crystal with dimensions $0.10 \times 0.09 \times 0.01 \mathrm{~mm}^{3}$ was selected for intensity measurements. The unit cell was monoclinic with the space group $P 21$. Lattice constants with $\mathrm{Z}=2, \rho_{\text {calcd }}=1.084 \mathrm{~g} \mathrm{~cm}^{-3}, \mu(\mathrm{MoK} \alpha)=$ $0.069 \mathrm{~mm}^{-1}, F(000)=2,072,2 \theta_{\max }=54.94^{\circ}$ were $a=16.291(2) \AA, b=15.030(2), c=24.604(4) \AA$, and $V=5881.7(15) \AA^{3}$. A total of 49,215 reflections was collected, of which 26,180 reflections were independent $\left(R_{\text {int }}=0.0622\right)$. The structure was refined to final $R_{1}=0.1161$ for 16,994 data $[I>2 \sigma(I)]$ with 1,426 parameters and $w R_{2}=0.3025$ for all data, $G O F=1.111$, and residual electron density $\max / \min =0.748 /-0.365 \mathrm{e}^{-3}$. The ORTEP drawing is shown in Figure $\mathrm{S} 1$ and crystal data and structure refinement are listed in Table S1.

Data collection and processing were conducted using the Rigaku CrystalClear software package. ${ }^{\mathrm{S} 5}$ The structure was solved by direct methods using Sir2004 ${ }^{\mathrm{S} 6}$ and refined by full-matrix least squares methods on $F^{2}$ with SHELXL-97 program $^{\mathrm{S} 7}$ using Yadokari-XG 2009. ${ }^{\mathrm{S} 8}$ All nonhydrogen atoms were refined anisotropically. All hydrogen atoms were calculated geometrically and refined using the riding model. Crystallographic data have been deposited at the CCDC (12 Union Road, Cambridge CB2 1EZ, UK) and copies can be obtained on request, free of charge, by quoting the publication citation and the deposition number 1445714. 


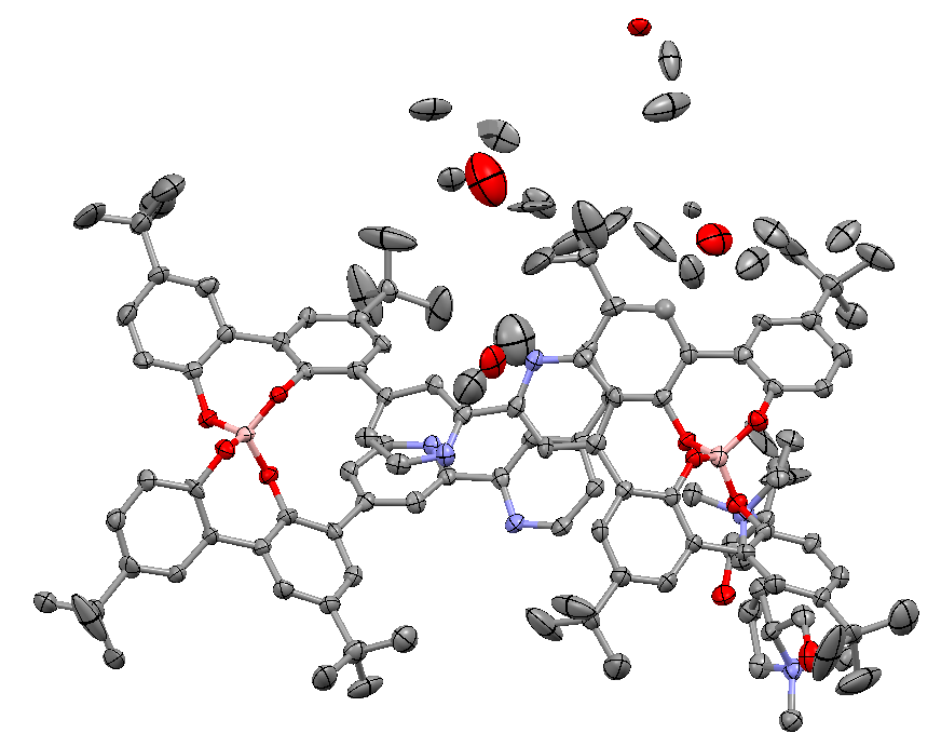

Figure S1. ORTEP drawing of the crystal structure of $(P)-(-)-\mathbf{D H} 3_{[(\boldsymbol{R})-5] 2}$ with thermal ellipsoids at $50 \%$ probability.

Table S1. Crystal data and structure refinement for $(P)-(-)-\mathbf{D H} \mathbf{3}_{[(\boldsymbol{R})-5 \mid 2}$

Empirical formula

Formula weight

Temperature

Wavelength

Crystal system

Space group

Unit cell dimensions

Volume

Z

Density (calculated)

Absorption coefficient

$\mathrm{F}(000)$

Crystal size

Theta range for data collection

Index ranges

Reflections collected

Independent reflections

Completeness to theta $=27.47^{\circ}$

Absorption correction

Max. and min. transmission

Refinement method

Data / restraints / parameters

Goodness-of-fit on $\mathrm{F}^{2}$

Final R indices [I $>2 \operatorname{sigma}(\mathrm{I})]$

$\mathrm{R}$ indices (all data)

Largest diff. peak and hole

CCDC reference number
$\mathrm{C}_{122} \mathrm{H}_{156} \mathrm{~B}_{2} \mathrm{~N}_{6} \mathrm{O}_{12}$

1920.15

103(2) K

$0.71075 \AA$

Monoclinic

$P 21$

$\mathrm{a}=16.291(2) \AA$

$\mathrm{b}=15.030(2) \AA$

$\mathrm{c}=24.604(4) \AA$

5881.7(15) $\AA^{3}$

2

$1.084 \mathrm{Mg} / \mathrm{m}^{3}$

$0.069 \mathrm{~mm}^{-1}$

2072

$0.10 \times 0.09 \times 0.01 \mathrm{~mm}^{3}$

3.00 to $27.57^{\circ}$.

$-17<=\mathrm{h}<=21,-19<=\mathrm{k}<=17,-31<=\mathrm{l}<=31$

49215

$26180\left[R_{\text {int }}=0.0622\right]$

$99.2 \%$

Semi-empirical from equivalents

0.9993 and 0.9932

Full-matrix least-squares on $\mathrm{F}^{2}$

26180 / 145 / 1426

1.111

$R_{1}=0.1161, w R_{2}=0.2697$

$R_{1}=0.1649, w R_{2}=0.3025$

0.748 and $-0.365 \mathrm{e}^{-3}$

1445714 


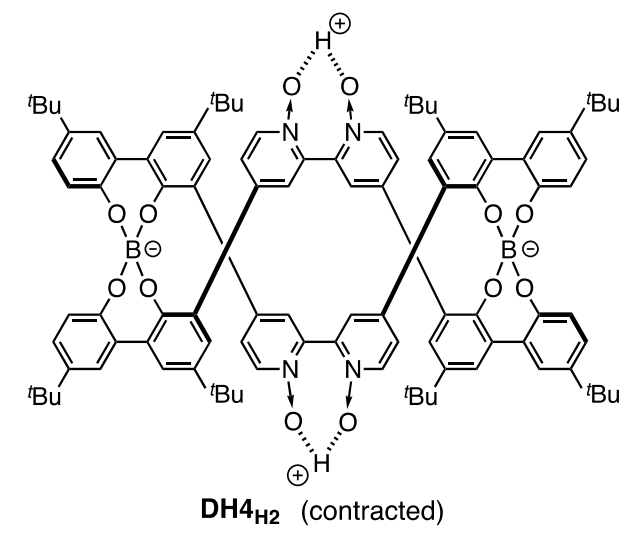

\section{Crystallographic Data of $\mathrm{DH} 4_{\mathrm{H} 2}$}

X-ray diffraction data set for $\mathbf{D H} \mathbf{H}_{\mathbf{H} 2}$ was collected on a Rigaku Saturn $724+$ CCD diffractometer with Mo Ka radiation $(l=0.71075 \AA)$ at $103 \mathrm{~K}$. Single crystals of $\mathbf{D H} \mathbf{4}_{\mathbf{H} 2}\left[\mathrm{C}_{108} \mathrm{H}_{122} \mathrm{~B}_{2} \mathrm{~N}_{4} \mathrm{O}_{14}, \mathbf{M W}=\right.$ 1721.72] suitable for X-ray analysis were obtained by the slow diffusion of $n$-hexane into a THF solution of $\mathrm{DH}_{\mathbf{H} 2}$ in the presence of TFA (3 equiv), and a single colorless crystal with dimensions $0.11 \times 0.11 \times 0.02 \mathrm{~mm}^{3}$ was selected for intensity measurements. The unit cell was monoclinic with the space group $C 2 / c$. Lattice constants with $\mathrm{Z}=4, r_{\text {calcd }}=1.216 \mathrm{~g} \mathrm{~cm}^{-3}, m($ MoKa $)=0.079 \mathrm{~mm}^{-1}$, $F(000)=3,680,2 \theta_{\max }=52.00^{\circ}$ were $a=14.485(3) \AA, b=32.392(8), c=20.582(5) \AA$, and $V=$ 9,403(4) $\AA^{3}$. A total of 35,027 reflections was collected, of which 9,194 reflections were independent $\left(R_{\text {int }}=0.0849\right)$. The structure was refined to final $R_{1}=0.1769$ for 6,710 data $[I>2 \sigma(I)]$ with 626 parameters and $w R_{2}=0.3775$ for all data, $G O F=1.230$, and residual electron density $\max / \min =0.932 /-0.538 \mathrm{e}^{-3}$. The ORTEP drawing is shown in Figure S2 and crystal data and structure refinement are listed in Table $\mathrm{S} 2$.

Data collection and processing were conducted using the Rigaku CrystalClear software package. ${ }^{\mathrm{S} 5}$ The structure was solved by direct methods using Sir2004 ${ }^{\mathrm{S} 6}$ and refined by full-matrix least squares methods on $F^{2}$ with SHELXL-97 program $^{\mathrm{S} 7}$ using Yadokari-XG 2009. ${ }^{\mathrm{S} 8}$ All nonhydrogen atoms were refined anisotropically. All hydrogen atoms were calculated geometrically and refined using the riding model. Crystallographic data have been deposited at the CCDC (12 Union Road, Cambridge CB2 1EZ, UK) and copies can be obtained on request, free of charge, by quoting the publication citation and the deposition number 1445715. 


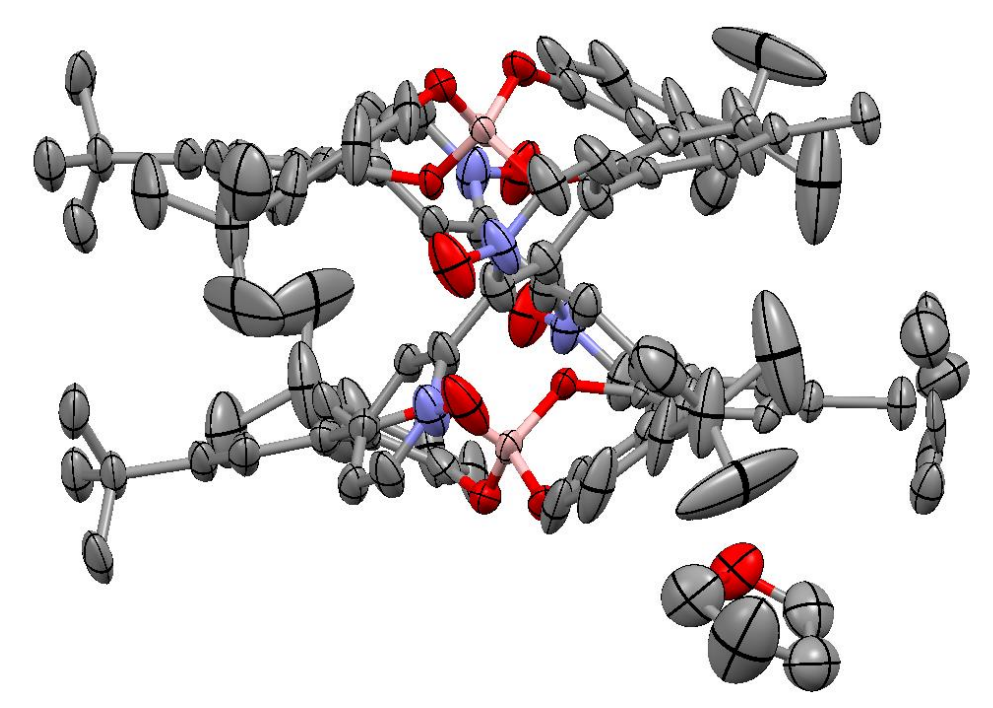

Figure S2. ORTEP drawing of the crystal structure of $\mathbf{D H} 4 \mathrm{H}_{2}$ with thermal ellipsoids at $50 \%$ probability.

Table S2. Crystal data and structure refinement for $\mathbf{D H} 4_{\mathbf{H} 2}$

Empirical formula

Formula weight

Temperature

Wavelength

Crystal system

Space group

Unit cell dimensions

Volume

Z

Density (calculated)

Absorption coefficient

$\mathrm{F}(000)$

Crystal size

Theta range for data collection

Index ranges

Reflections collected

Independent reflections

Completeness to theta $=26.00^{\circ}$

Absorption correction

Max. and min. transmission

Refinement method

Data / restraints / parameters

Goodness-of-fit on $\mathrm{F}^{2}$

Final R indices [I $>2 \operatorname{sigma}(\mathrm{I})]$

$\mathrm{R}$ indices (all data)

Largest diff. peak and hole

CCDC reference number
$\mathrm{C}_{108} \mathrm{H}_{122} \mathrm{~B}_{2} \mathrm{~N}_{4} \mathrm{O}_{14}$

1721.72

103(2) K

$0.71075 \AA$

Monoclinic

$C 2 / c$

$\mathrm{a}=14.485(3) \AA$

$\mathrm{b}=32.392(8) \AA$

$\mathrm{c}=20.582(5) \AA$

9403(4) $\AA^{3}$

4

$1.216 \mathrm{Mg} / \mathrm{m}^{3}$

$0.079 \mathrm{~mm}^{-1}$

3680

$0.11 \times 0.11 \times 0.02 \mathrm{~mm}^{3}$

3.10 to $26.00^{\circ}$.

$-17<=\mathrm{h}<=15,-39<=\mathrm{k}<=39,-25<=1<=25$

35027

$9194\left[R_{\text {int }}=0.0849\right]$

$99.4 \%$

Semi-empirical from equivalents

0.9984 and 0.9913

Full-matrix least-squares on $\mathrm{F}^{2}$

9194 / 24 / 626

1.230

$R_{1}=0.1769, w R_{2}=0.3540$

$R_{1}=0.2170, w R_{2}=0.3775$

0.932 and $-0.538 \mathrm{e}^{-3}$

1445715 
Theoretical Studies on the Structures of the Extended and Contracted Helicates $(P)-D H 3 H 2$ and $(P)-D H 4{ }_{H}$, and Extended Helicate $(P)-\mathrm{DH}^{2+}$.

The molecular modeling was performed on a Windows $7 \mathrm{PC}$ with the ArgusLab software. ${ }^{\mathrm{S} 9}$ The initial structures were constructed based on the crystal structure of the extended helicate $\mathbf{D H} \mathbf{3}^{2+}$ or contracted DH4 H2. The initial models were then fully optimized by the semi-empirical molecular orbital (MO) calculations (PM6 method ${ }^{\mathrm{S} 10}$ in MOPAC2012 ${ }^{\mathrm{S} 11}$ ) and the geometries were further refined by the density functional theory (DFT) calculations at the B3LYP level and the 6-31G* basis set in Gaussian 09 software (Gaussian, Inc., Pittsburgh, PA) ${ }^{\mathrm{S} 12}$. Computer resources for the DFT calculations were provided by the Information Technology Center of Nagoya University. The resultant energy-minimized structures with their total energies (except for $(P)$-DH3 ${ }^{2+}$ ) are depicted in Figures S3 and S4. 
a)

\section{Front view}

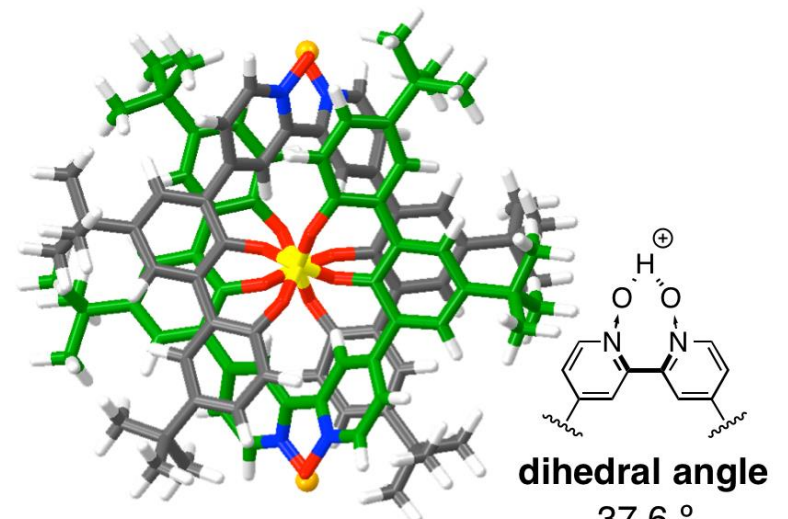

\section{Side view}

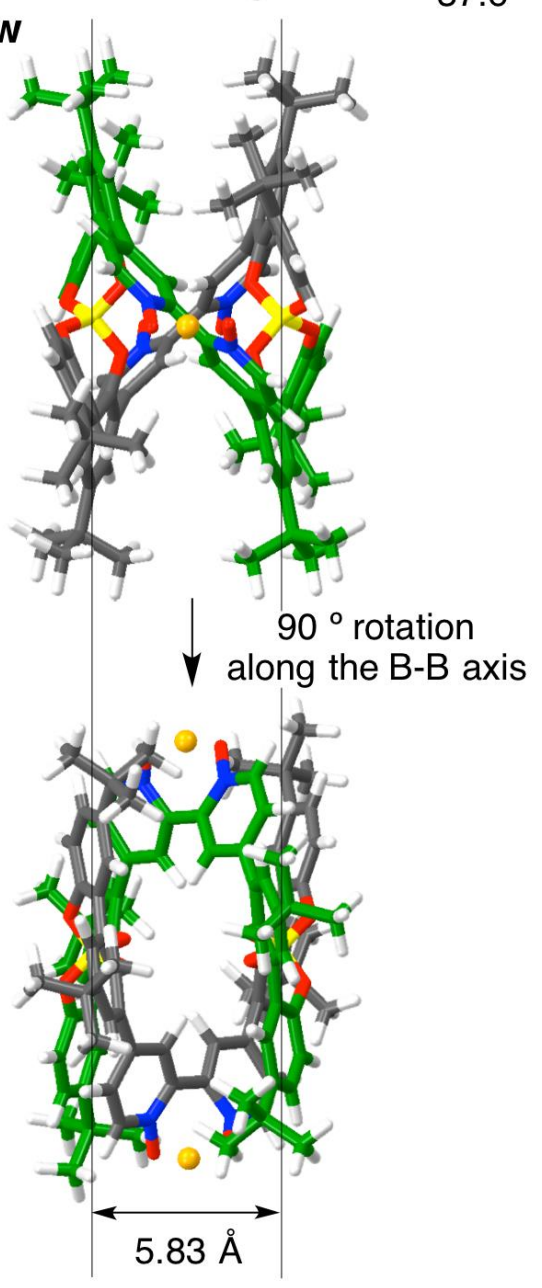

$E_{\text {Contracted }}=-5046.0946$ a.u.

b)
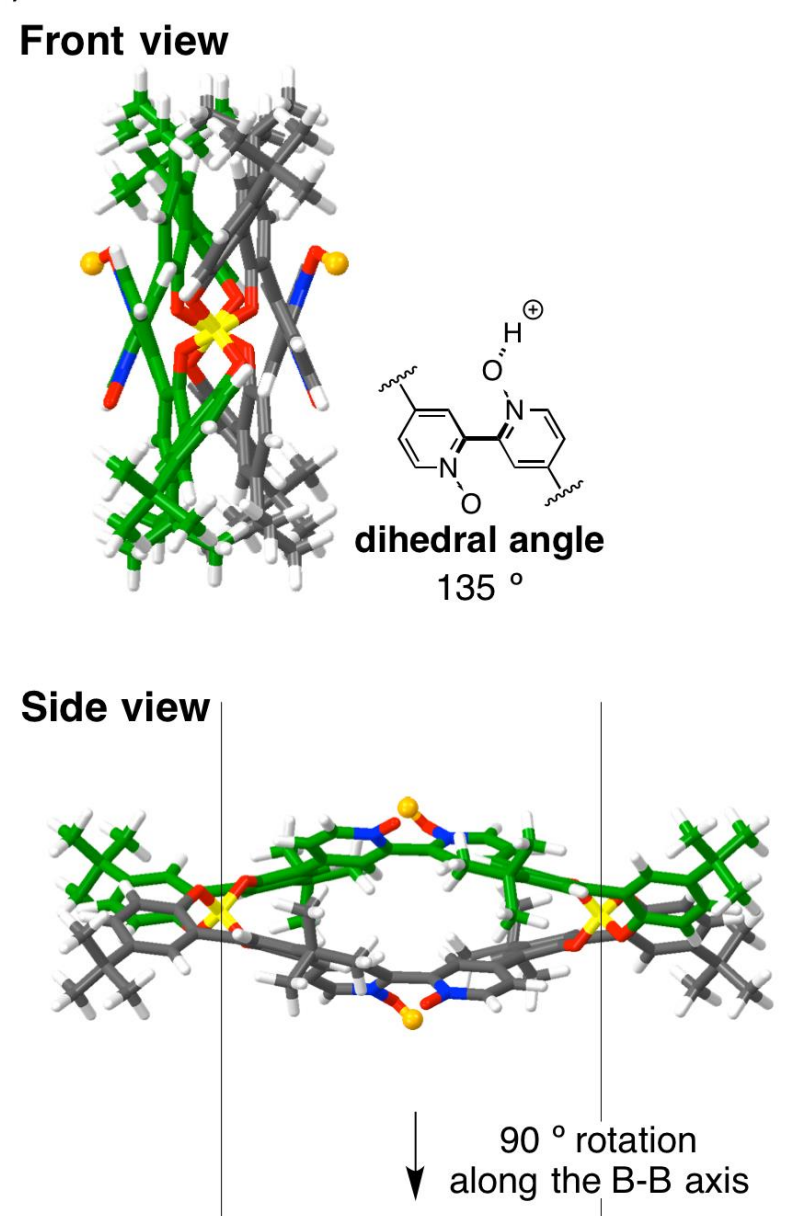

$E_{\text {Contracted }}-E_{\text {Extended }}=-63.9 \times 10^{-3}$ a.u. $=-40.1 \mathrm{kcal} \mathrm{mol}^{-1}$

Figure S3. The energy-minimized right-handed double-helical structures of contracted $\mathbf{D H} \mathbf{4}_{\mathbf{H} 2}$ (a) and extended $\mathbf{D H}_{4} \mathbf{H}_{2}$ (b) obtained by DFT calculations. Protons $\left(\mathrm{H}^{+}\right)$are highlighted as an orange ball. DFT calculated energies are also shown in the bottom. 
a)

\section{Front view}

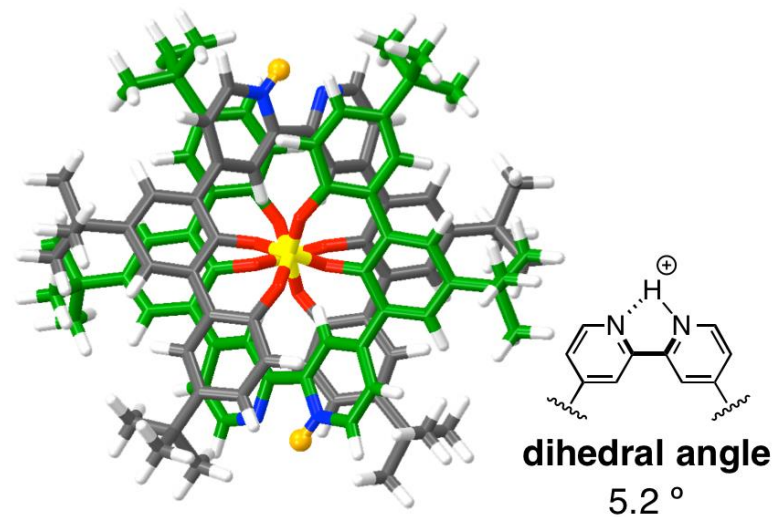

\section{Side view}
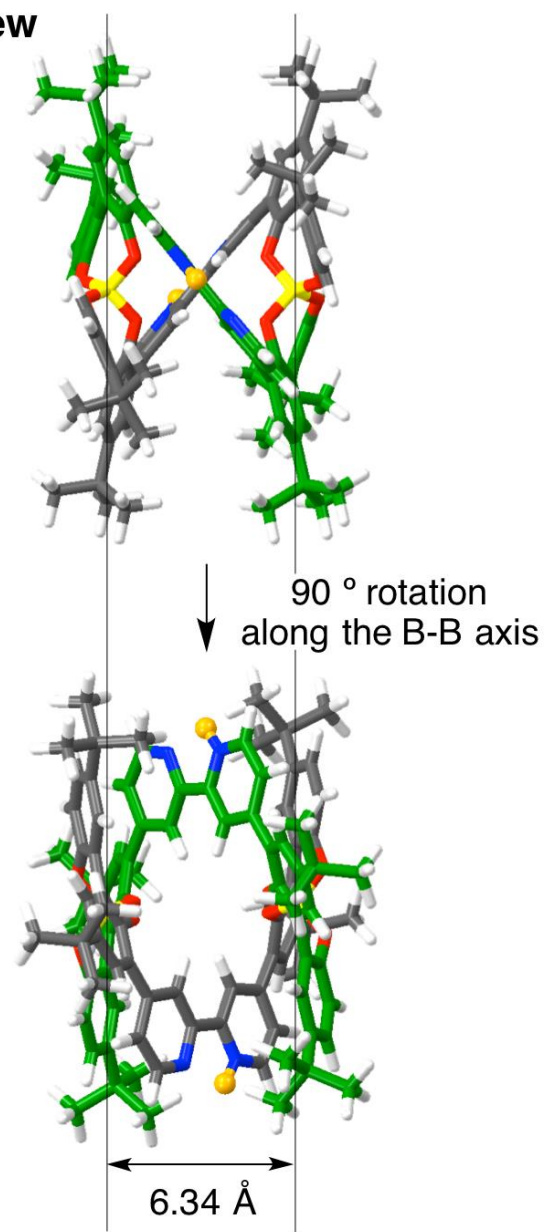

$E_{\text {Contracted }}=-4745.4422$ a.u. b)

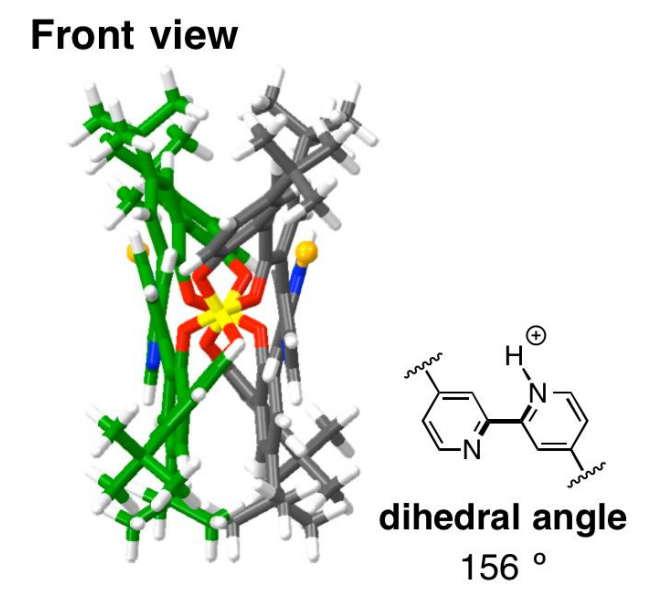

$156^{\circ}$
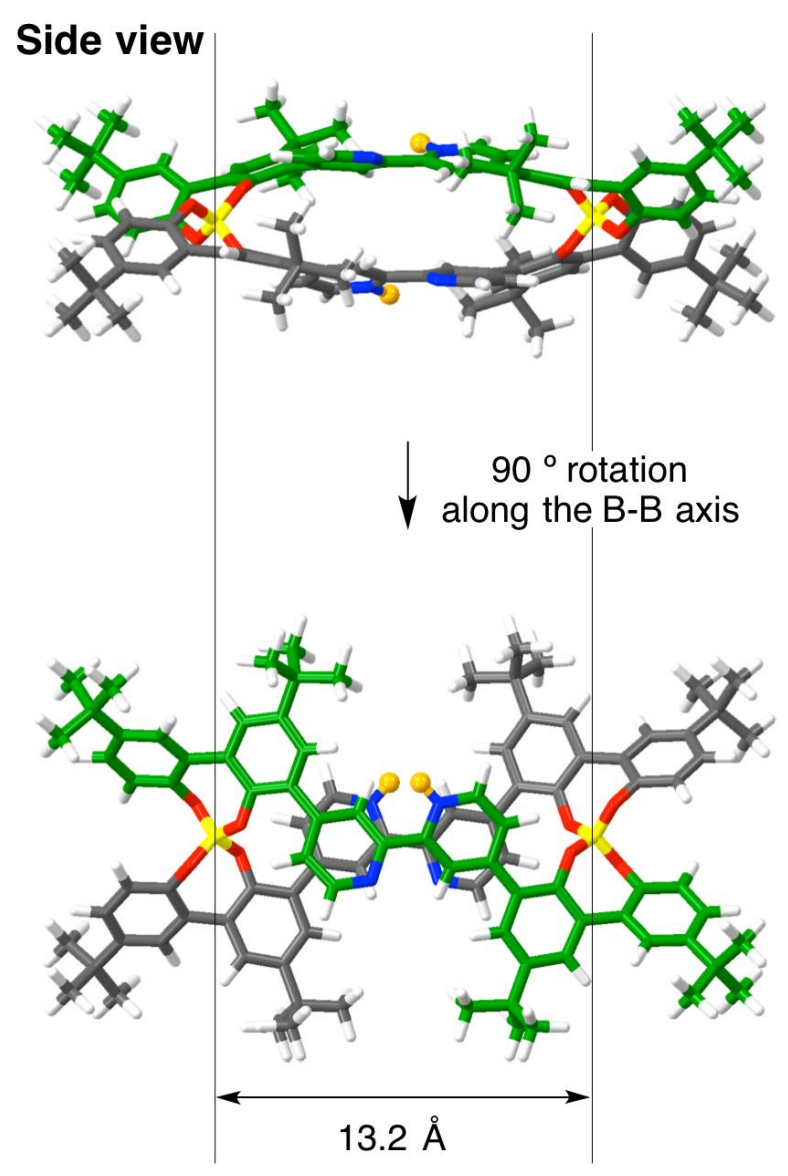

$E_{\text {Extended }}=-4745.4121$ a.u.

$$
E_{\text {Contracted }}-E_{\text {Extended }}=-30.1 \times 10^{-3} \text { a.u. }=-18.9 \mathrm{kcal} \mathrm{mol}^{-1}
$$

Figure S4. The energy-minimized right-handed double-helical structures of contracted $\mathbf{D H}_{\mathbf{H}}$ (a) and extended $\mathbf{D H}_{\mathbf{H}}$ (b) obtained by DFT calculations. Protons $\left(\mathrm{H}^{+}\right)$are highlighted as an orange ball. DFT calculated energies are also shown in the bottom. 


\section{Helix-Sense Determination of (-)-DH4тва2.}

In order to determine the helical sense of $(-)$-DH4 4BA2, the right-handed helicate $(P)-(-)-$ DH3 ${ }_{\text {TBA2, }}$, whose helical sense had been unambiguously determined by its X-ray crystallographic analysis (Figure $\mathrm{S} 1$ ), was directly converted to $(-)-\mathbf{D H 4} \mathbf{T B A 2}$ by the following procedure: $(P)-(-)$ DH3 ${ }_{\text {TBA2 }}(4.23 \mathrm{mg}, 2.12 \mu \mathrm{mol})$ and $m$ CPBA containing ca. 30\% water $(5.23 \mathrm{mg}$, ca. $21.2 \mu \mathrm{mol})$ were dissolved in $\mathrm{CD}_{2} \mathrm{Cl}_{2}(2.0 \mathrm{~mL})$ under nitrogen. The reaction mixture was stirred at room temperature for $22 \mathrm{~h}$. After the reaction was almost completed, to this was added diethyl ether (5.0 $\mathrm{mL})$. The precipitate was collected by filtration and washed with diethyl ether $(2.5 \mathrm{~mL} \times 2)$, affording a helicate DH4 TrA2 $(3.25 \mathrm{mg})$, which was then used for spectroscopic measurements $\left({ }^{1} \mathrm{H}\right.$ NMR, ESI mass, UV-vis, and CD) without further purification (Figure S30).

As shown in Figure S30a, the ${ }^{1} \mathrm{H}$ NMR spectrum of the helicate DH4 TBA2 prepared from the separated right-handed $(P)-(-)$-DH3 $\mathbf{T B A 2}_{2}$ with $m \mathrm{CPBA}$ in $\mathrm{CD}_{3} \mathrm{CN}$ was almost identical to that of the enantiopure (-)-DH4TBA2 obtained by the optical resolution of $( \pm)-\mathbf{D H} \mathbf{4 H}_{\mathbf{H} 2}$ (Figure S27), except for $\mathrm{TBA}^{+}$and the residual $m$ CPBA peaks. Thus, the $(P)-(-)-\mathbf{D H 3}$ твA2 was fully converted to DH4 $\mathbf{T B A 2}$, as supported by its ESI mass measurement (Figure S30b). In addition, the absorption and CD spectral patterns of the helicate DH4 TBa2 were also identical to those of the enantiopure (-)DH4твA2, although its CD intensity is approximately 2.5 times smaller than that of (-)-DH4 TвA2 (Figure S30c), indicating that partial racemization took place during the $N$-oxidation reaction (ee of DH4 $4_{\text {TBA2 }}=$ ca. 40\%). Nevertheless, the helical sense of $(-)-\mathbf{D H 4} \mathbf{T B A 2}_{2}$ can be unambiguously determined to be right-handed. 


\section{Binding Isotherm Analysis.}

Plots of DH4 TBA2 absorption intensity changes ( $\triangle \mathrm{Abs})$ at $400 \mathrm{~nm}$ as a function of $[\mathrm{TFA}] /\left[\mathbf{D H} 4_{\mathrm{TBA}}\right]_{0}$ gave a saturation binding isotherm in DMSO at $25{ }^{\circ} \mathrm{C}$. The cooperative protonbinding process was analyzed according to the following Hill equation,

$$
\log (Y /(1-Y))=n_{\mathrm{H}} \log [\mathrm{TFA}]_{\mathrm{free}}+\log K_{\mathrm{a}}
$$

where $Y, n_{\mathrm{H}},[\mathrm{TFA}]_{\text {free}}$, and $K_{\mathrm{a}}$ are the fractional saturation $(\Delta \mathrm{Abs} / \Delta \mathrm{Abs}$ max $)$, the Hill coefficient, the concentration of free TFA, and the apparent association constant, respectively. ${ }^{\mathrm{S} 13}$

The $n_{\mathrm{H}}$ and $K$ were estimated from the slope and the intercept of the linear plots (Hill plot), respectively (Figure 5). It should be noted that the $K_{\mathrm{a}}$ value of $\mathrm{H}^{+}$to $\mathbf{D H} \mathbf{3}_{\text {TBA2 }}$ in DMSO was too high to be determined, which is at least $10^{5}$ times greater than that to DH4 TBA2 judging from the ${ }^{1} \mathrm{H}$ NMR spectrum of $\mathbf{D H 3} \mathbf{H}_{2}$ (1 equiv) in the presence of DH4tba2 (10 equiv) in DMSO- $d_{6}$ (competitive proton binding experiment), where possible cation exchange products (DH3 $\mathbf{T B A 2}_{\mathbf{2}}$ and DH4H2) were not observed under this experimental condition (Figure S39).

\section{General Procedure for Exchange Spectroscopy (EXSY) Experiments.}

The EXSY (2D NOESY) measurements ${ }^{\mathrm{S} 14}$ were conducted at $25{ }^{\circ} \mathrm{C}$ at various mixing times $\left(\tau_{\mathrm{m}}\right)$. The exchange rate constants, $k_{\mathrm{ex}}$, were determined by the following equations:

$$
\begin{aligned}
& \stackrel{\underset{k_{\mathrm{BA}}}{\stackrel{k_{\mathrm{AB}}}{\rightleftarrows}} \mathrm{B}}{k_{\mathrm{ex}}}=k_{\mathrm{AB}}+k_{\mathrm{BA}} \\
& \quad=\left(1 / \tau_{\mathrm{m}}\right) \ln [(r+1) /(r-1)]
\end{aligned}
$$

where $r$ is defined as the following equation,

$$
r=4 \mathrm{X}_{\mathrm{A}} \mathrm{X}_{\mathrm{B}}\left(I_{\mathrm{AA}}+I_{\mathrm{BB}}\right) /\left(I_{\mathrm{AB}}+I_{\mathrm{BA}}\right)-\left(\mathrm{X}_{\mathrm{A}}-\mathrm{X}_{\mathrm{B}}\right)^{2}
$$

where $\mathrm{X}_{\mathrm{A}}$ and $\mathrm{X}_{\mathrm{B}}$ are the mole fractions of $\mathrm{A}$ and $\mathrm{B}$, respectively, $I_{\mathrm{AB}}$ and $I_{\mathrm{BA}}$ are the peak volumes of the cross peaks between the signals $\mathrm{A}$ and $\mathrm{B}$, respectively, and $I_{\mathrm{AA}}$ and $I_{\mathrm{BB}}$ are the peak volumes of the diagonal signals.

The $k_{\text {ex }}$ values of DH3 ${ }_{\text {TBA2 }}$ and DH4TBA2 in the presence of 1 equiv of TFA (a 1:1 mixture of contracted and extended helicates) were estimated from the initial slope of the linear plots of $\ln [(r+$ $1) /(r-1)]$ as a function of $\tau_{m}$ (Figures S42 and S43). 


\section{Supporting References}

(S1) Miwa, K.; Furusho, Y.; Yashima, E., Nat. Chem. 2010, 2, 444-449.

(S2) Casnati, G. Tetrahedron 1992, 48, 9483-9494.

(S3) V. Maier, J. Horáková, J. Petr, D. Drahoňovský, J. Ševčík, J. Chromatogr. A 2006, 1103, 337-343.

(S4) Guijarro, D.; Martínez, P. J.; Nájera, C.; Yus, M. ARKIVOC 2004, 2004, 5-13.

(S5) CrystalClear, Version 1.36; Molecular Structure Corporation: The Woodlands, TX, 2000 and Rigaku Corporation: Tokyo, Japan.

(S6) Burla, M. C.; Caliandro, R.; Camalli, M.; Carrozzini, B.; Cascarano, G. L.; Caro, L. D.; Giacovazzo, C.; Polidori, G.; Spagna, R. J. Appl. Crystallogr. 2005, 38, 381-388.

(S7) (a) Sheldrick, G. M. SHELXL-97: Program for the Refinement of Crystal Structures; University of Göttingen, Göttingen, Germany, 1997. (b) Sheldrick, G. M. Acta Crystallogr. 2008, A64, 112-122.

(S8) (a) Wakita, K. Yadokari-XG, Program for Crystal Structure Analysis; 2000. (b) Kabuto, C.; Akine, S.; Kwon, E. J. Cryst. Soc. Jpn. 2009, 51, 218-224.

(S9) Thompson, M. ArgusLab, Planaria Software LLC, Seattle, WA (1996).

(S10) Stewart, J. J. P. J. Mol. Model. 13, 1173-1213 (2007).

(S11) Stewart, J. J. P. MOPAC2012, Stewart Computational Chemistry, Colorado Springs, CO, USA, http://openmopac.net/ (2012).

(S12) Gaussian 09, Revision D.01, Frisch, M. J.; Trucks, G. W.; Schlegel, H. B.; Scuseria, G. E.; Robb, M. A.; Cheeseman, J. R.; Scalmani, G.; Barone, V.; Mennucci, B.; Petersson, G. A.; Nakatsuji, H.; Caricato, M.; Li, X.; Hratchian, H. P.; Izmaylov, A. F.; Bloino, J.; Zheng, G.; Sonnenberg, J. L.; Hada, M.; Ehara, M.; Toyota, K.; Fukuda, R.; Hasegawa, J.; Ishida, M.; Nakajima, T.; Honda, Y.; Kitao, O.; Nakai, H.; Vreven, T.; Montgomery, J. A., Jr.; Peralta, J. E.; Ogliaro, F.; Bearpark, M.; Heyd, J. J.; Brothers, E.; Kudin, K. N.; Staroverov, V. N.; Kobayashi, R.; Normand, J.; Raghavachari, K.; Rendell, A.; Burant, J. C.; Iyengar, S. S.; Tomasi, J.; Cossi, M.; Rega, N.; Millam, J. M.; Klene, M.; Knox, J. E.; Cross, J. B.; Bakken, V.; Adamo, C.; Jaramillo, J.; Gomperts, R.; Stratmann, R. E.; Yazyev, O.; Austin, A. J.; Cammi, R.; Pomelli, C.; Ochterski, J. W.; Martin, R. L.; Morokuma, K.; Zakrzewski, V. G.; Voth, G. A.; Salvador, P.; Dannenberg, J. J.; Dapprich, S.; Daniels, A. D.; Farkas, Ö.; Foresman, J. B.; Ortiz, J. V.; Cioslowski, J.; Fox, D. J. Gaussian, Inc., Wallingford CT, 2009.

(S13) Connors, K. A., Binding Constants; John Wiley \& Sons: New York, 1987.

(S14) Perrin, C. L.; Dwyer, T. J., Chem. Rev. 1990, 90, 935-967. 


\section{Supporting Data}
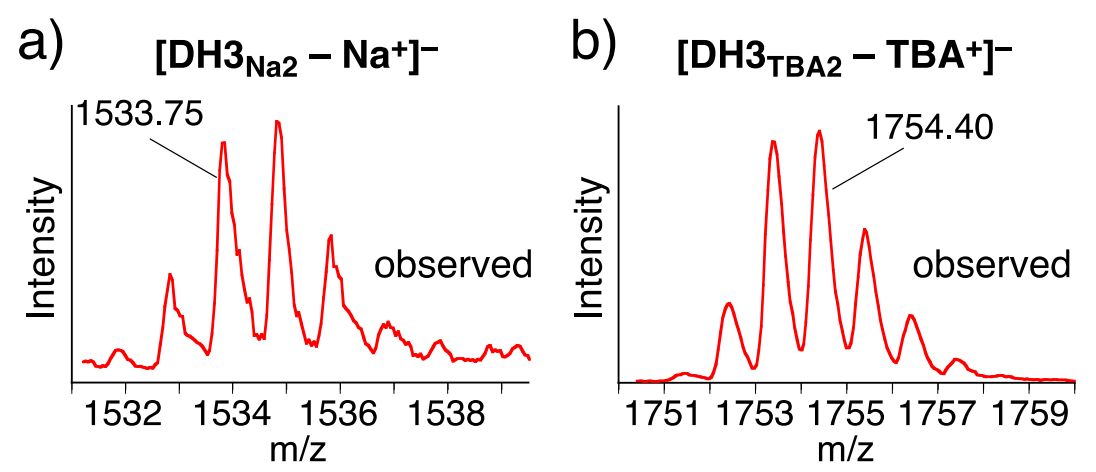

C) $\left[\mathrm{DH} 3_{\mathrm{H} 2}-\mathrm{H}^{+}\right]^{-}$
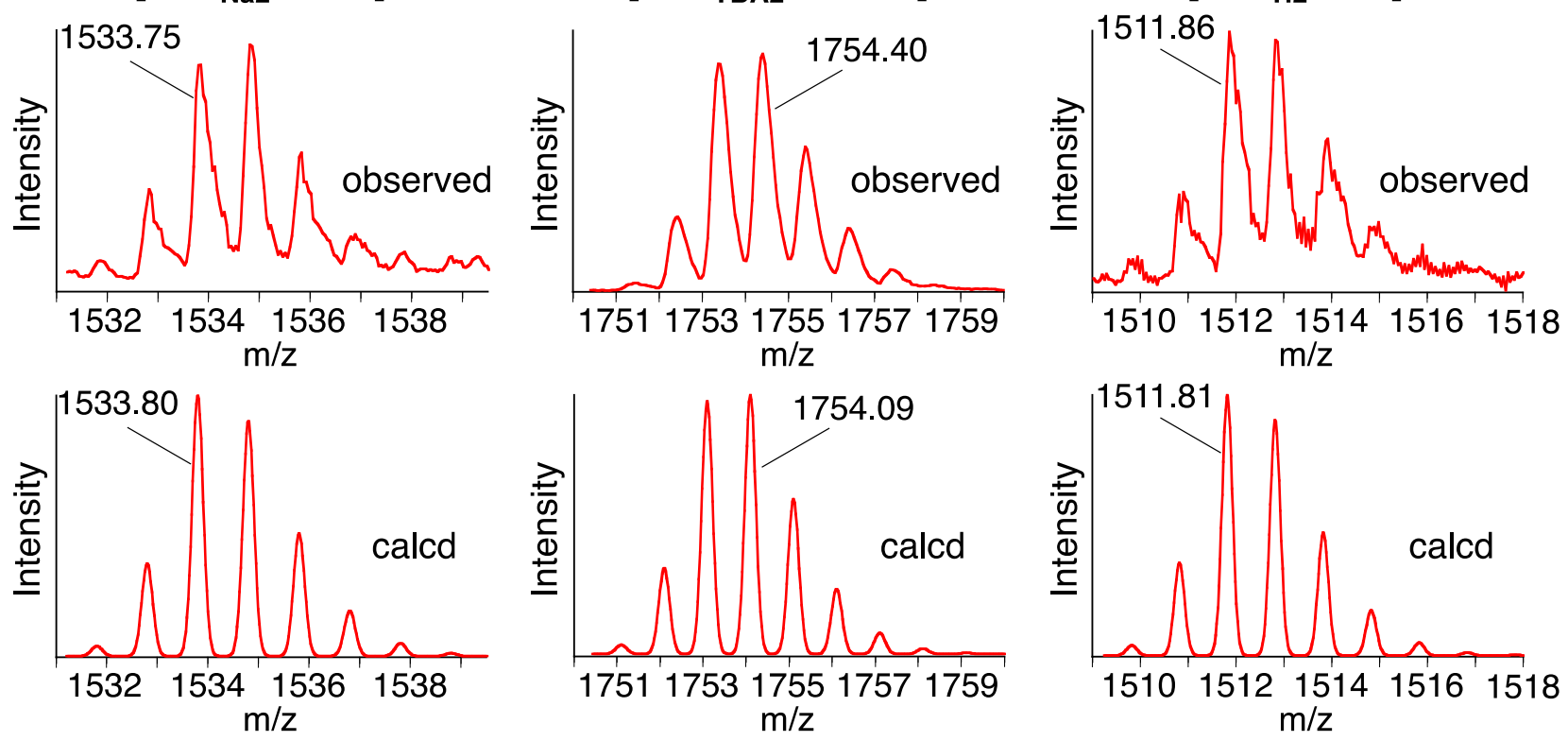

d) $\quad\left[\mathrm{DH} 4_{\mathrm{H} 2}-\mathrm{H}^{+}\right]^{-}$
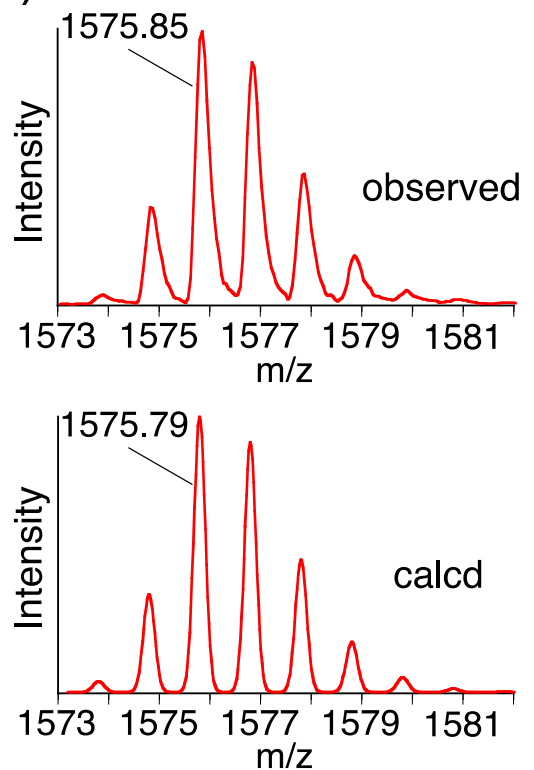

e) $\left[\mathrm{DH}_{\mathrm{TBA} 2}-\mathrm{TBA}^{+}\right]^{-}$
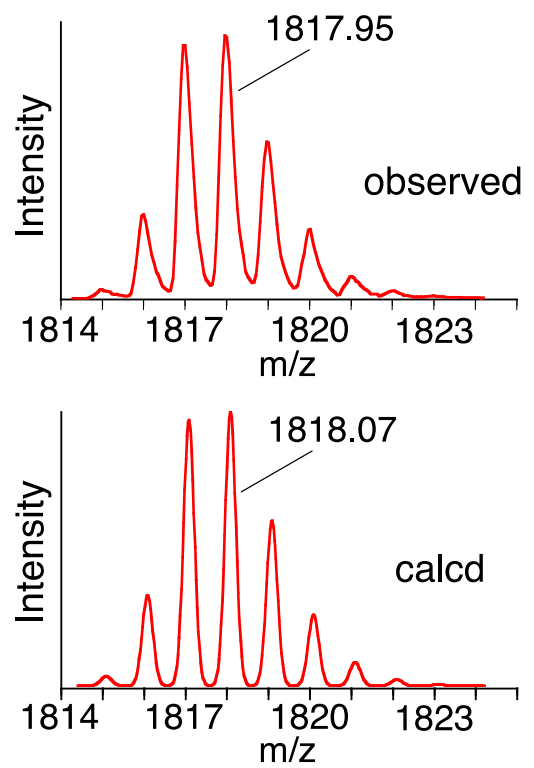

Figure S5. Negative mode ESI mass spectra of (a) DH3 $\mathbf{N a}_{\mathbf{N a}}$, (b) DH3 $\mathbf{D H}_{\mathrm{TB} 2}$, (c) $\mathbf{D H} \mathbf{3}_{\mathbf{H} 2}$, (d) DH4 $\mathbf{H}_{2}$, and (e) DH4твA2. 

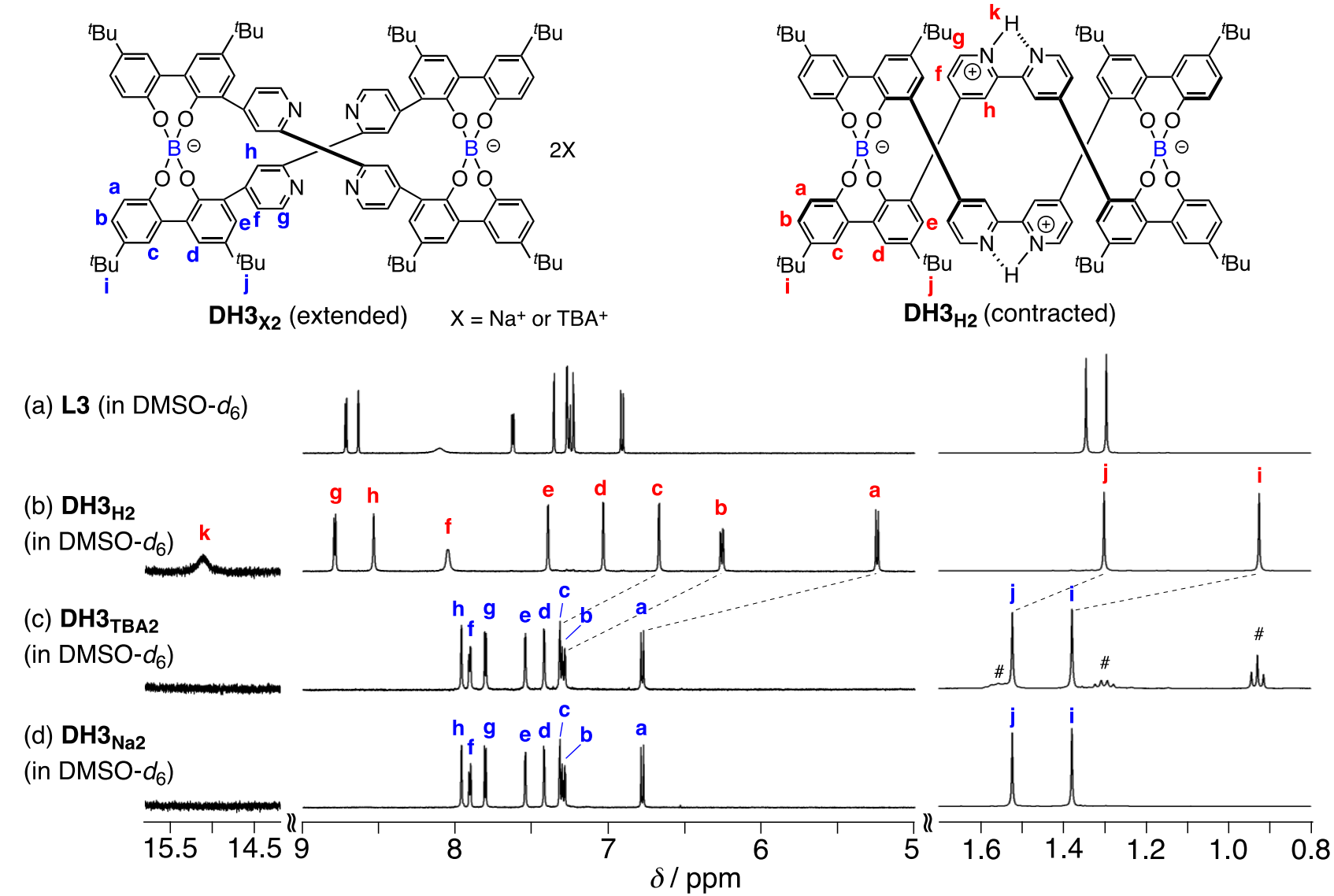

Figure S6. Partial ${ }^{1} \mathrm{H}$ NMR spectra $\left(500 \mathrm{MHz}, \mathrm{DMSO}-d_{6}, 25^{\circ} \mathrm{C}\right.$ ) of (a) L3, (b) DH3H2, (c) DH3 ${ }_{\text {TBA2, and (d) DH3 }}$ Na2. \# denotes the protons from TBA ${ }^{+}$. 

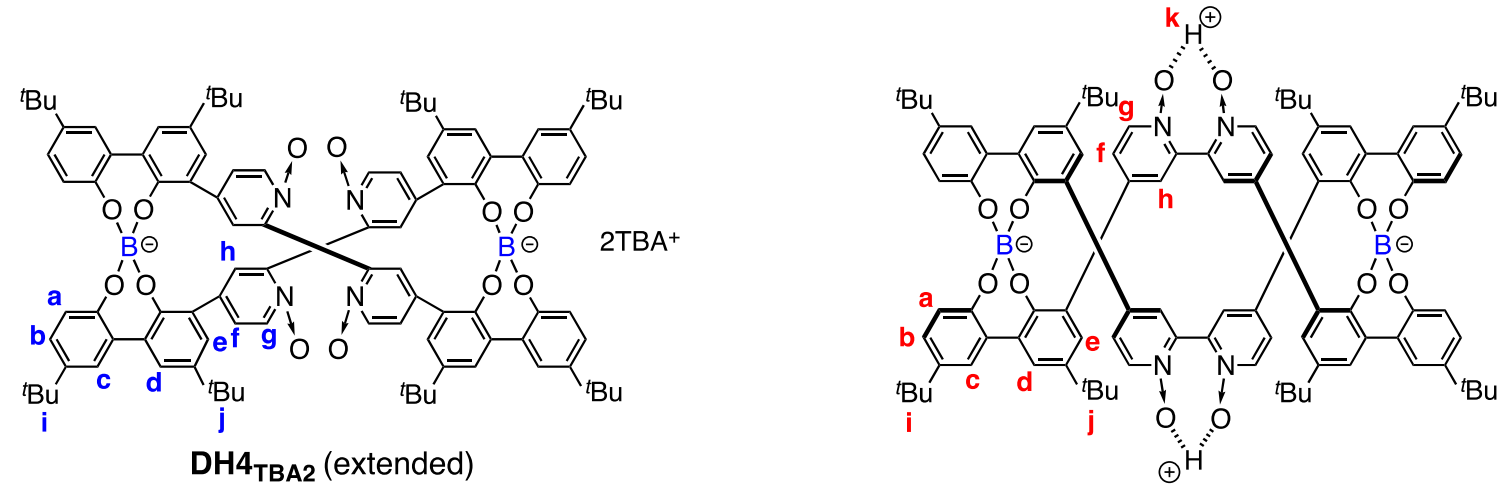

$\mathrm{DH}_{\mathrm{H} 2}$ (contracted)

(a) L4 (in DMSO- $d_{6}$ )
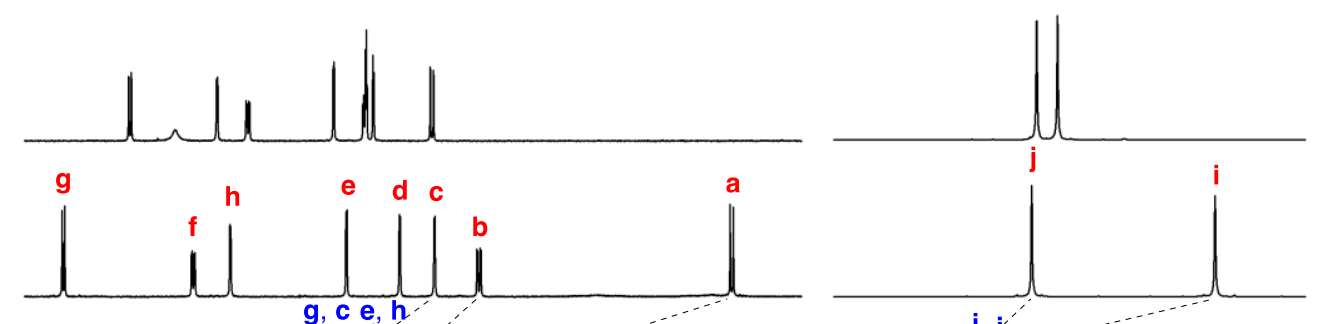

(c) $\mathrm{DH}_{\mathrm{TBA}}$ (in $\mathrm{CD}_{3} \mathrm{CN}$ )

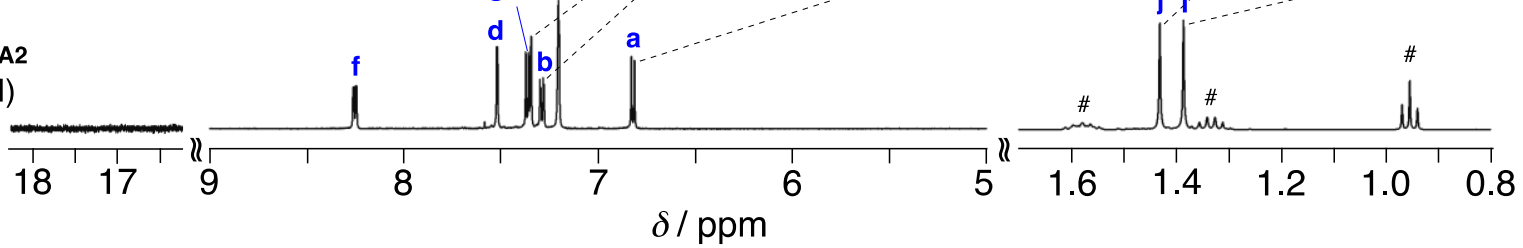

Figure S7. Partial ${ }^{1} \mathrm{H}$ NMR spectra $\left(500 \mathrm{MHz}, 25^{\circ} \mathrm{C}\right)$ of (a) $\mathbf{L 4}$ in DMSO- $d_{6}$, (b) DH4 $\mathbf{H 2}$ and (c) DH4tвA2 in $\mathrm{CD}_{3} \mathrm{CN}$. \# denotes the protons from $\mathrm{TBA}^{+}$. $\mathbf{L} 4$ was insoluble in $\mathrm{CD}_{3} \mathrm{CN}$. 

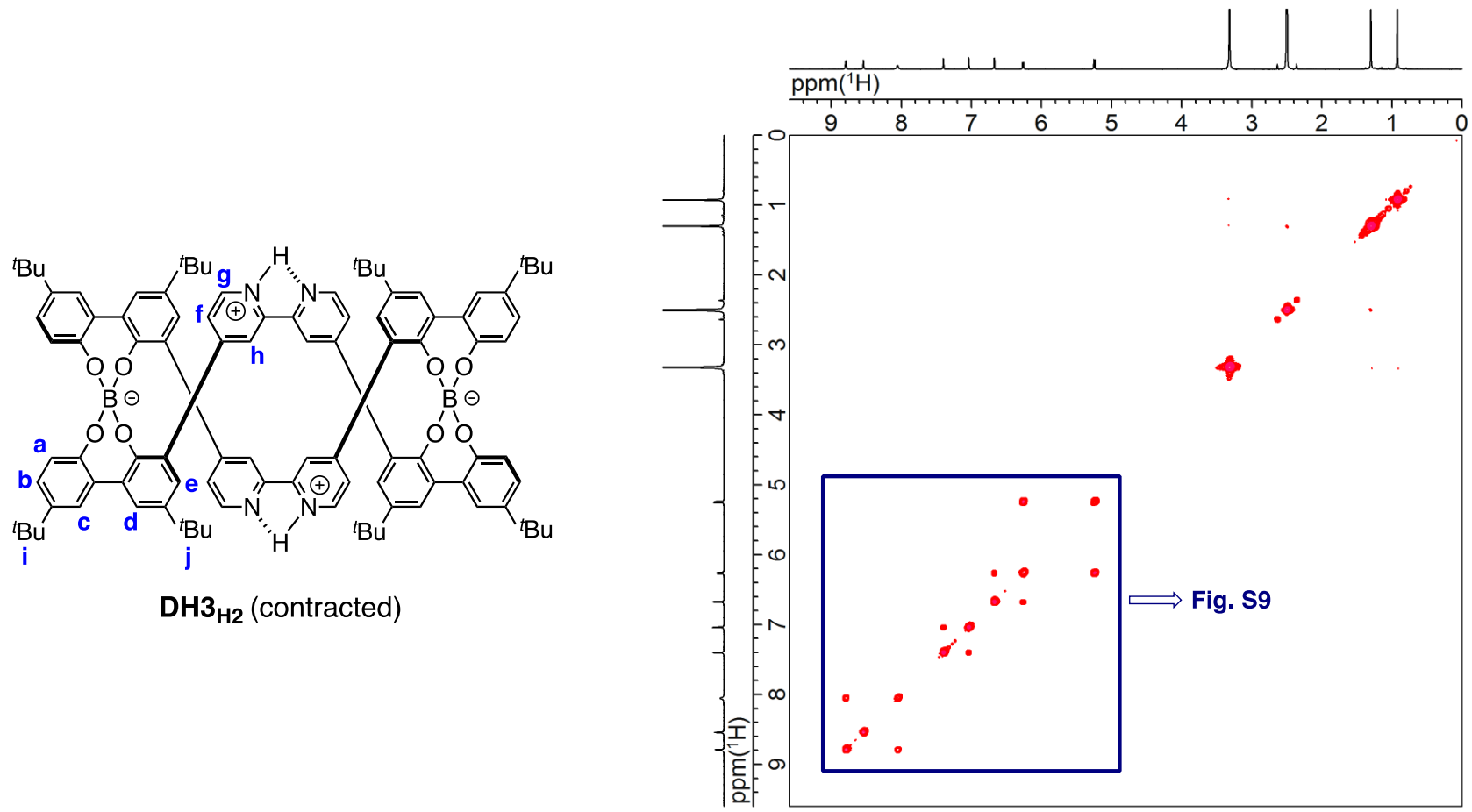

Figure S8. $500 \mathrm{MHz} g \mathrm{COSY}$ spectrum of $\mathbf{D H 3} \mathbf{H}_{2}\left(\mathrm{DMSO}-d_{6}, 0.6 \mathrm{mM}, 25^{\circ} \mathrm{C}\right)$.
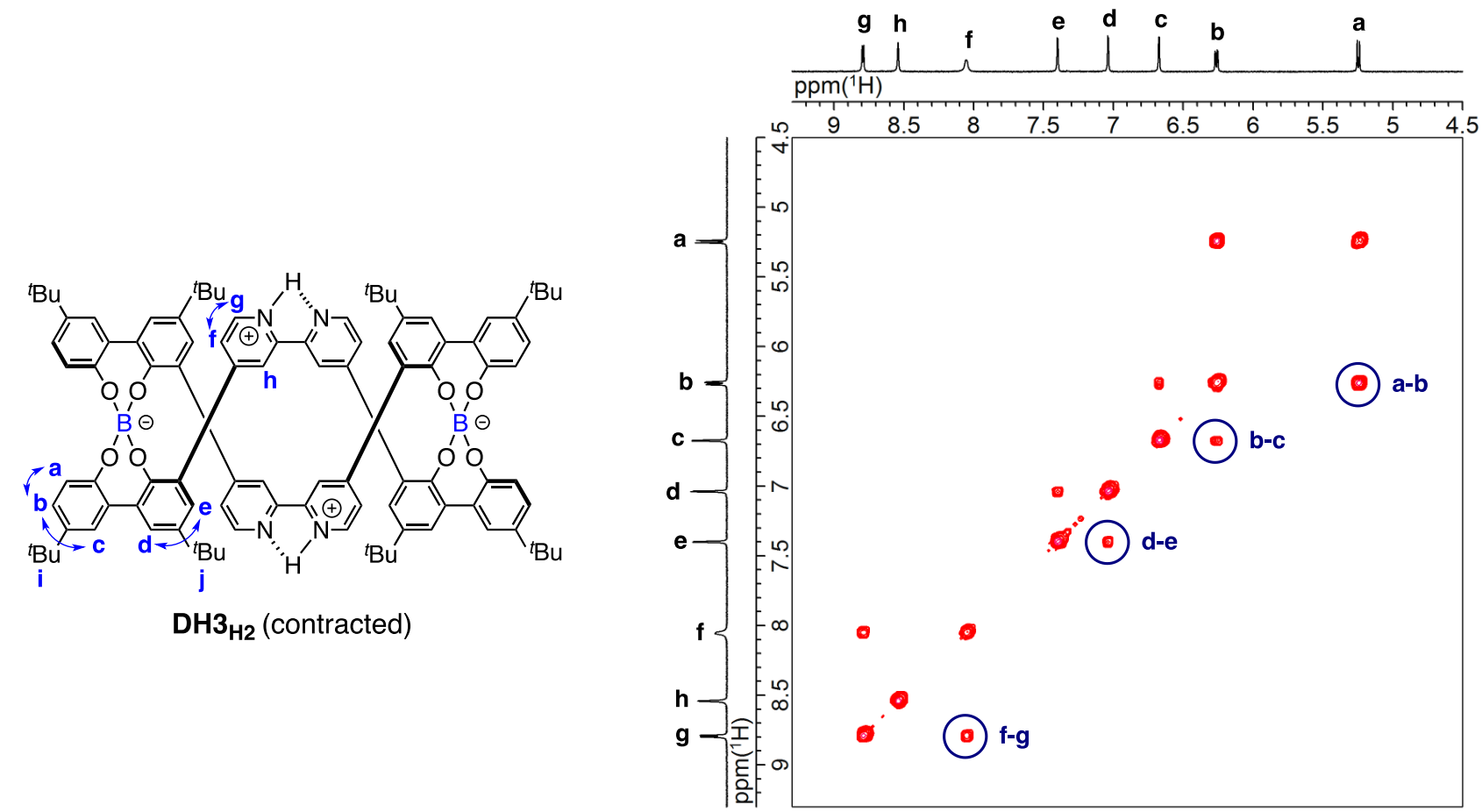

Figure S9. Partial $500 \mathrm{MHz} g \mathrm{COSY}$ spectrum of $\mathbf{D H 3} \mathbf{H}_{\mathbf{2}}\left(\mathrm{DMSO}-d_{6}, 0.6 \mathrm{mM}, 25^{\circ} \mathrm{C}\right)$. 

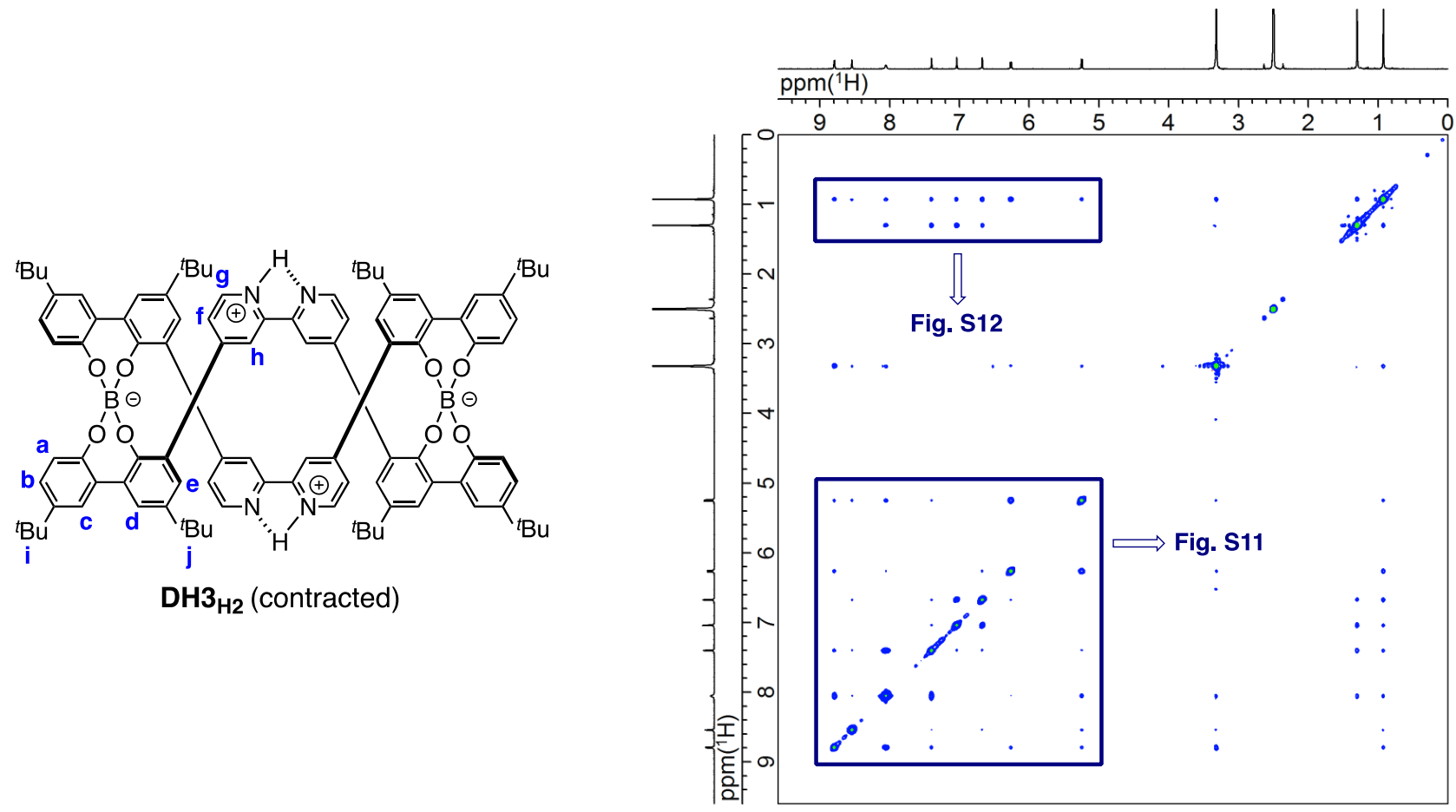

Figure S10. $500 \mathrm{MHz}$ NOESY spectrum of $\mathbf{D H 3} \mathrm{H}_{2}\left(\mathrm{DMSO}-d_{6}, 0.6 \mathrm{mM}, 25^{\circ} \mathrm{C}\right.$, mixing time $=500$ $\mathrm{ms})$.
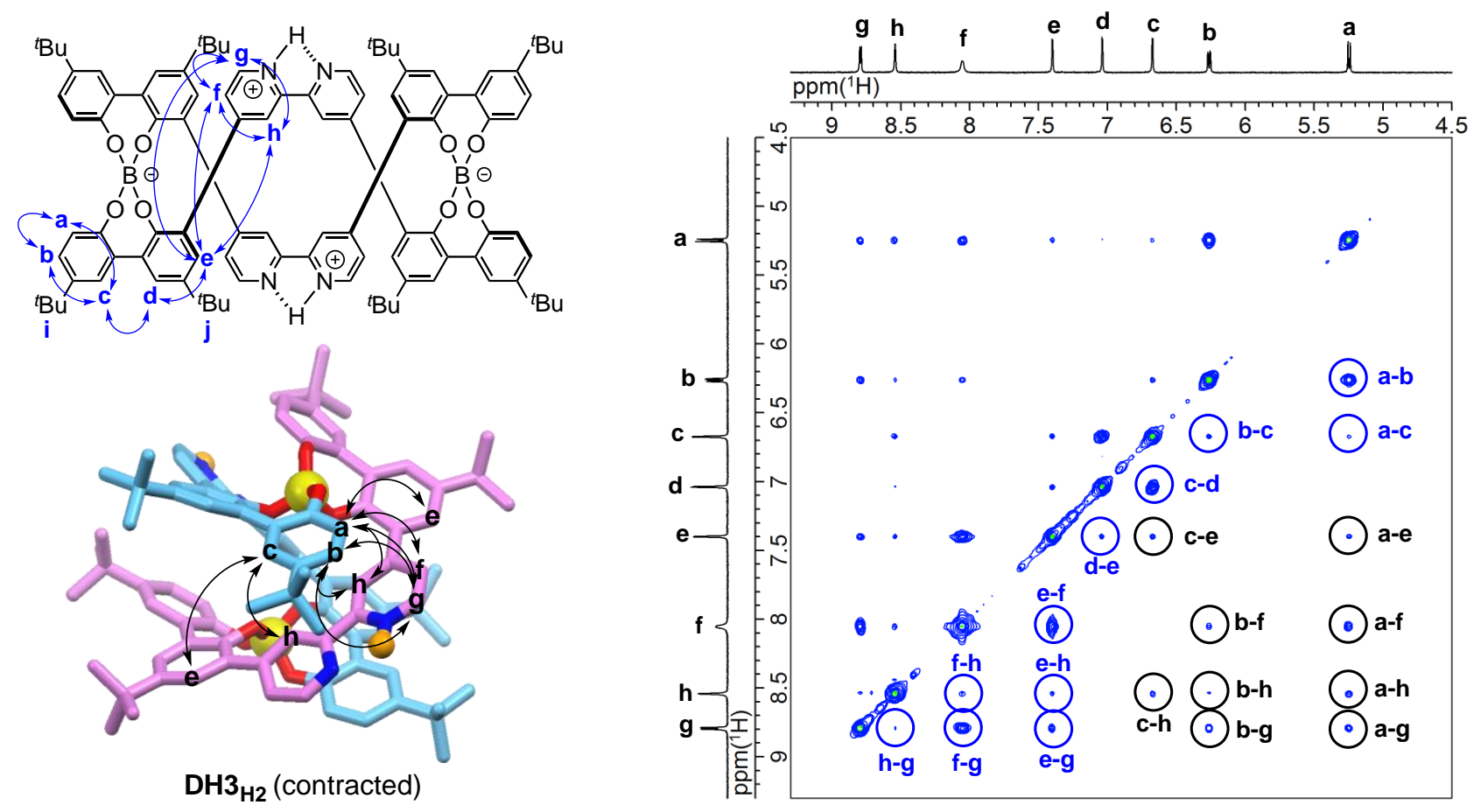

Figure S11. Partial 500 MHz NOESY spectrum of $\mathbf{D H 3} \mathbf{H}_{2}\left(\mathrm{DMSO}-d_{6}, 0.6 \mathrm{mM}, 25{ }^{\circ} \mathrm{C}\right.$, mixing time $=500 \mathrm{~ms}$ ). Interstrand NOE cross-peaks are indicated by arrows in the energy-minimized structure of $\mathrm{DH}_{\mathrm{H} 2}$ obtained by the DFT calculations. 

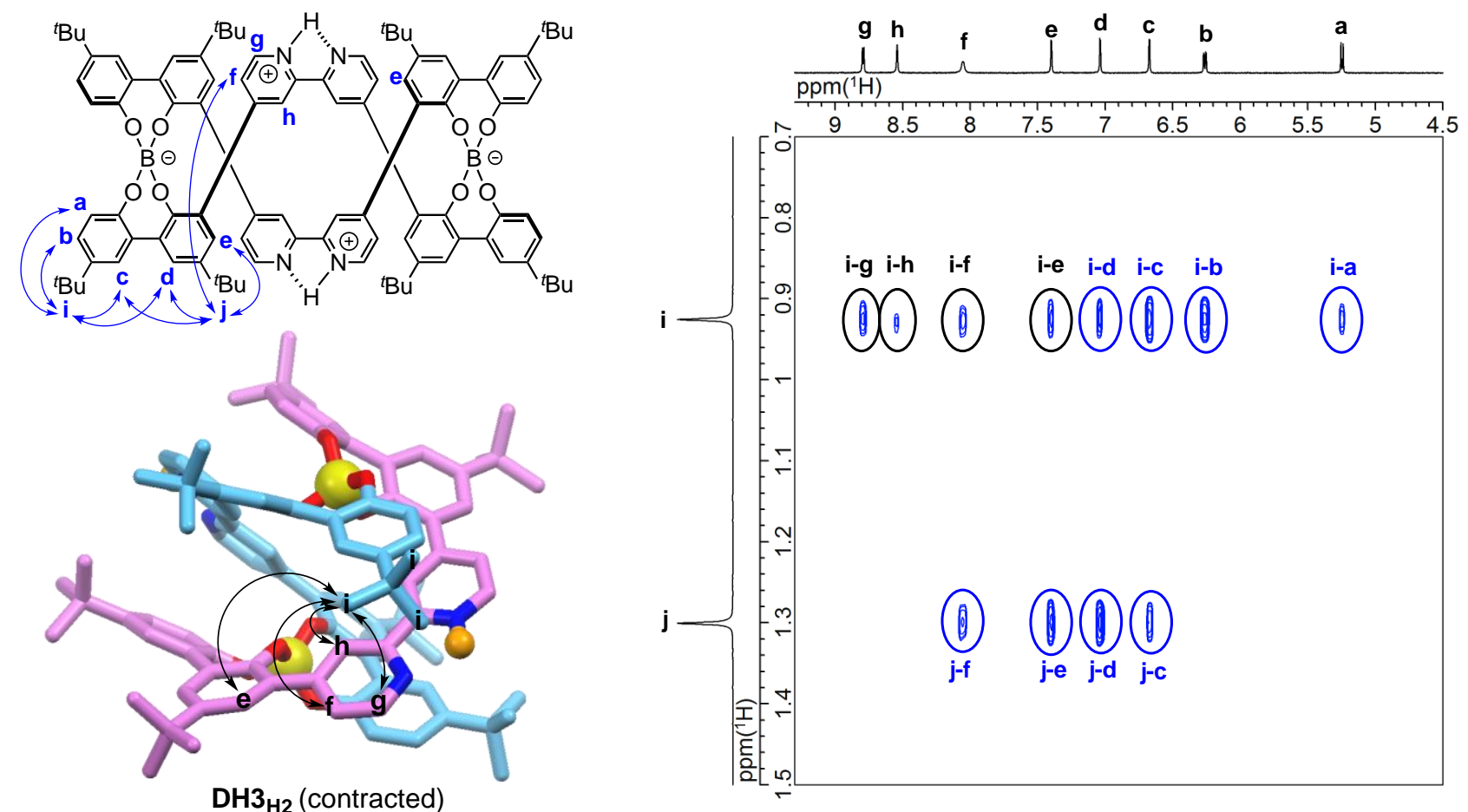

Figure S12. Partial $500 \mathrm{MHz}$ NOESY spectrum of $\mathbf{D H 3} \mathrm{H}_{2}$ (DMSO- $d_{6}, 0.6 \mathrm{mM}, 25{ }^{\circ} \mathrm{C}$, mixing time $=500 \mathrm{~ms}$ ). Interstrand NOE cross-peaks are indicated by arrows in the energy-minimized structure of $\mathrm{DH}_{\mathrm{H} 2}$ obtained by the DFT calculations. 

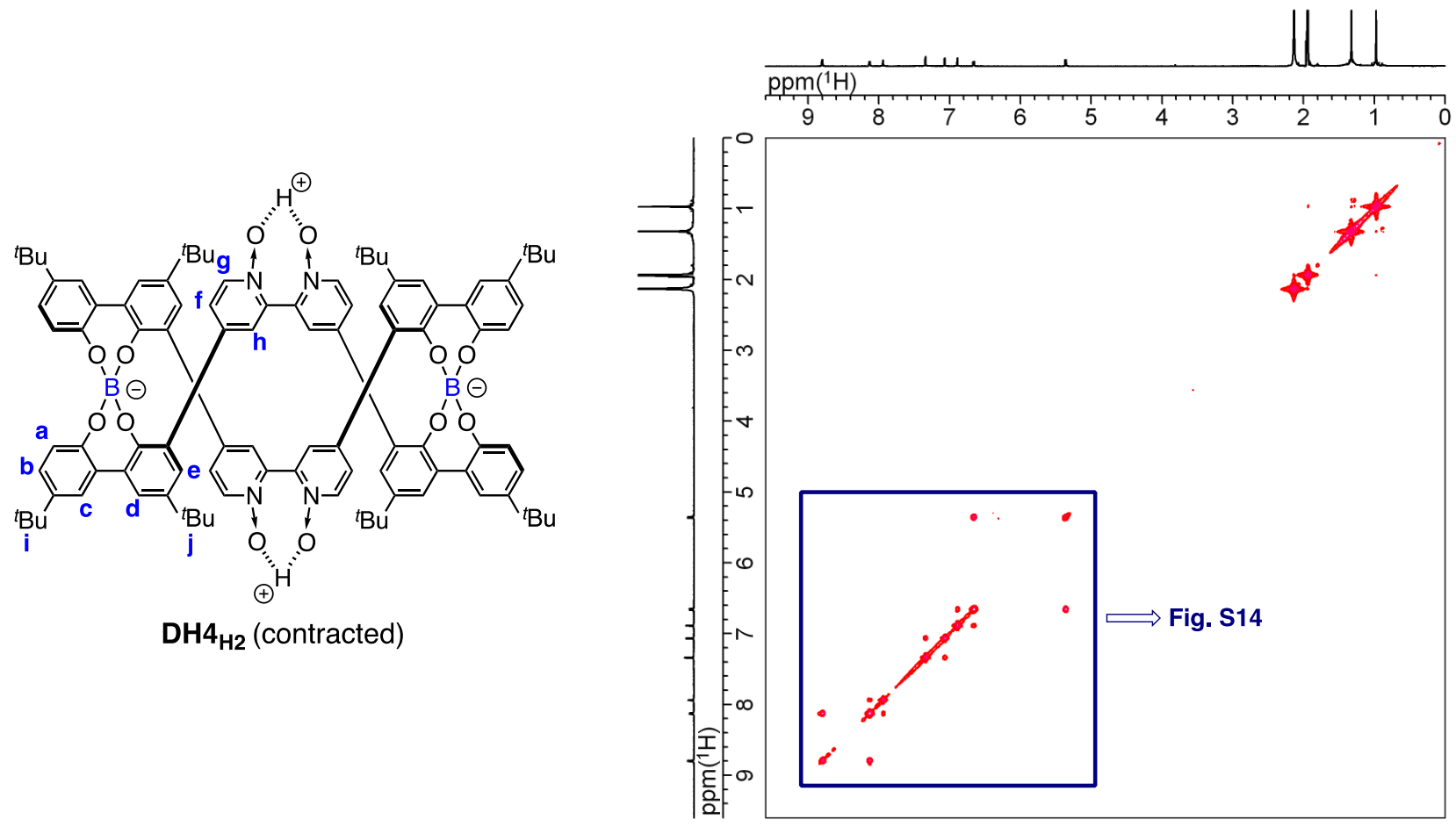

Figure S13. $g \mathrm{COSY}$ spectrum of DH4 $\mathrm{H}_{2}\left(500 \mathrm{MHz}, \mathrm{CD}_{3} \mathrm{CN}, 25^{\circ} \mathrm{C}, 1.2 \mathrm{mM}\right)$.

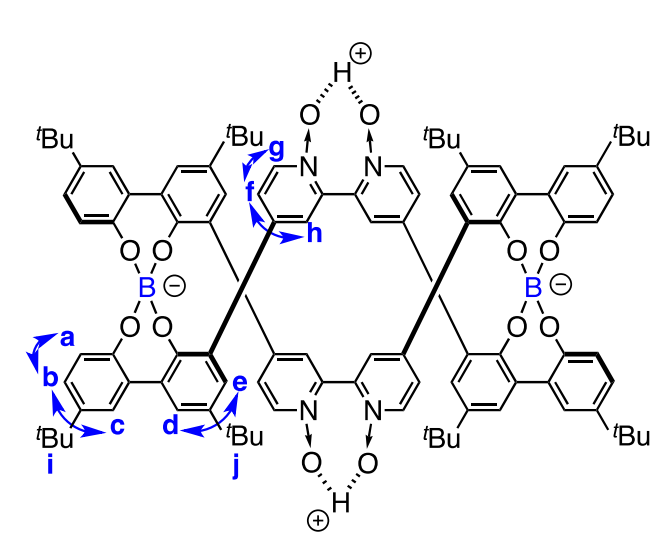

$\mathrm{DH}_{\mathrm{H} 2}$ (contracted)

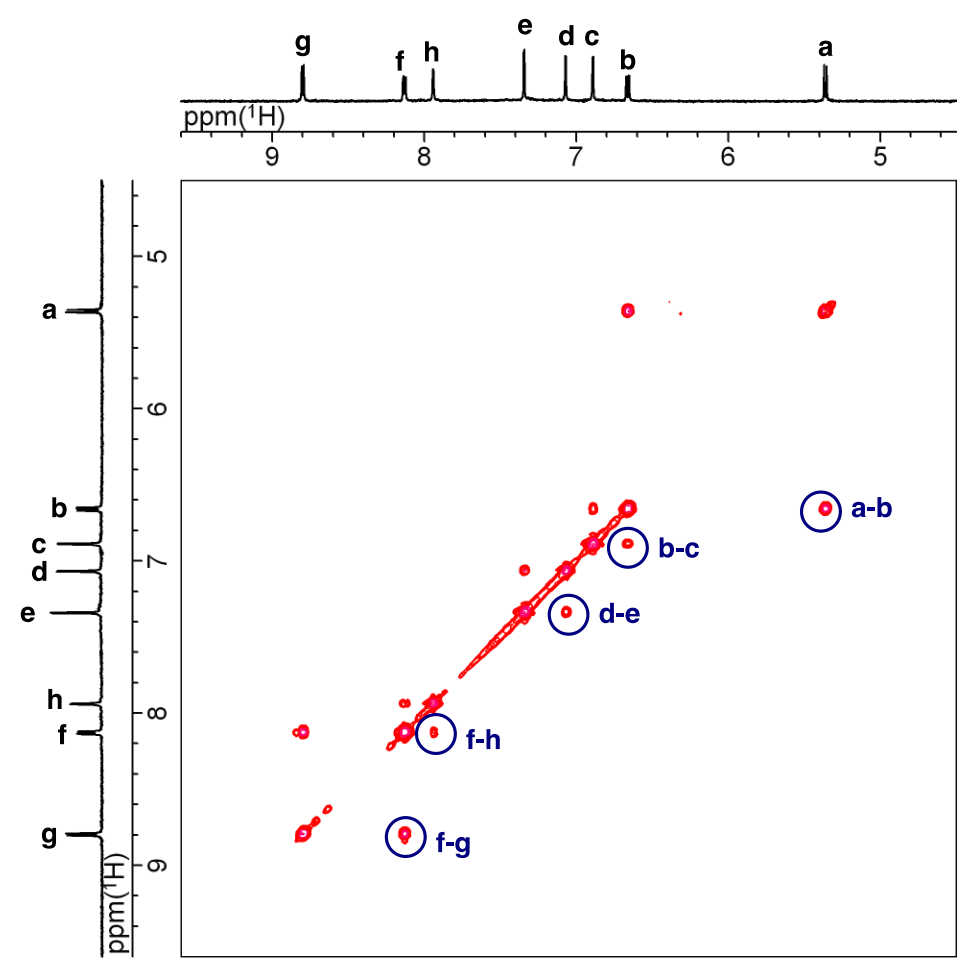

Figure S14. Partial $g \mathrm{COSY}$ spectrum of $\mathrm{DH}_{\mathrm{H} 2}\left(500 \mathrm{MHz}, \mathrm{CD}_{3} \mathrm{CN}, 25^{\circ} \mathrm{C}, 1.2 \mathrm{mM}\right)$. 


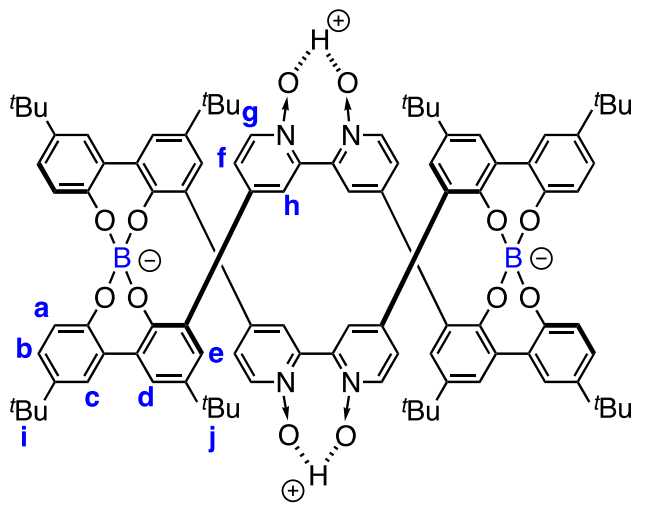

$\mathrm{DH}_{\mathrm{H} 2}$ (contracted)

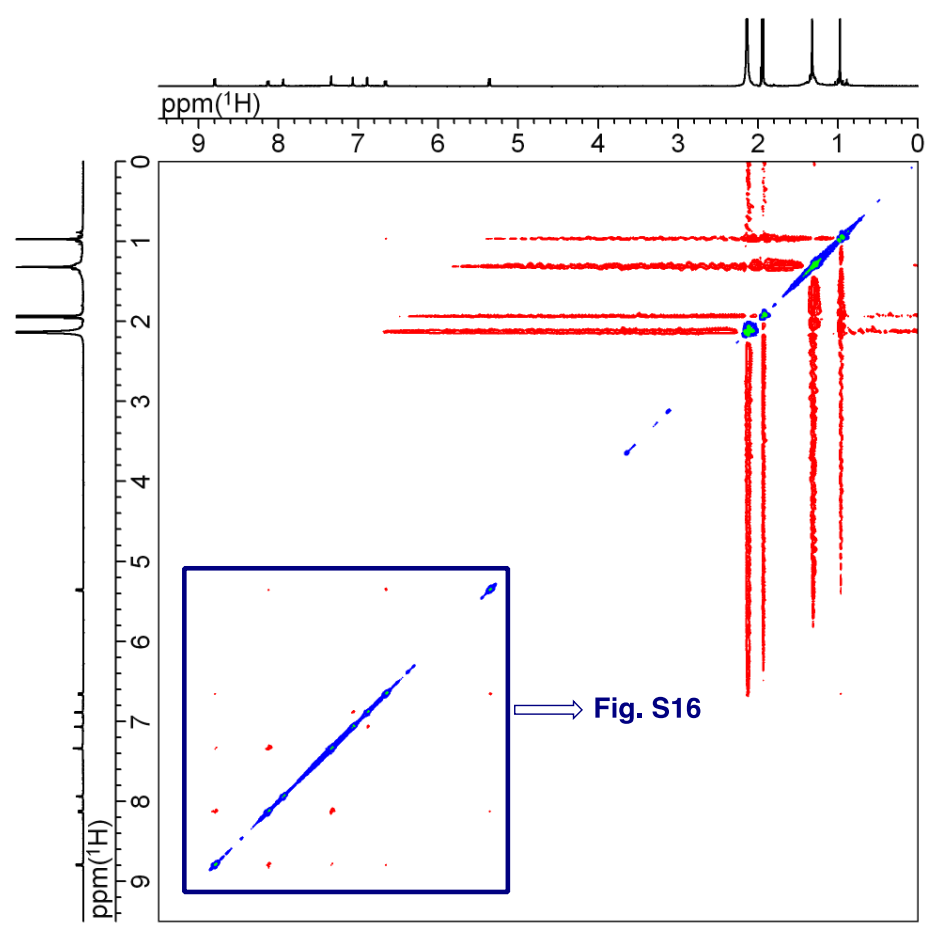

Figure S15. NOESY spectrum of $\mathbf{D H}_{\mathrm{H} 2}\left(500 \mathrm{MHz}, \mathrm{CD}_{3} \mathrm{CN}, 25{ }^{\circ} \mathrm{C}, 1.2 \mathrm{mM}\right.$, mixing time $=500$ $\mathrm{ms})$.
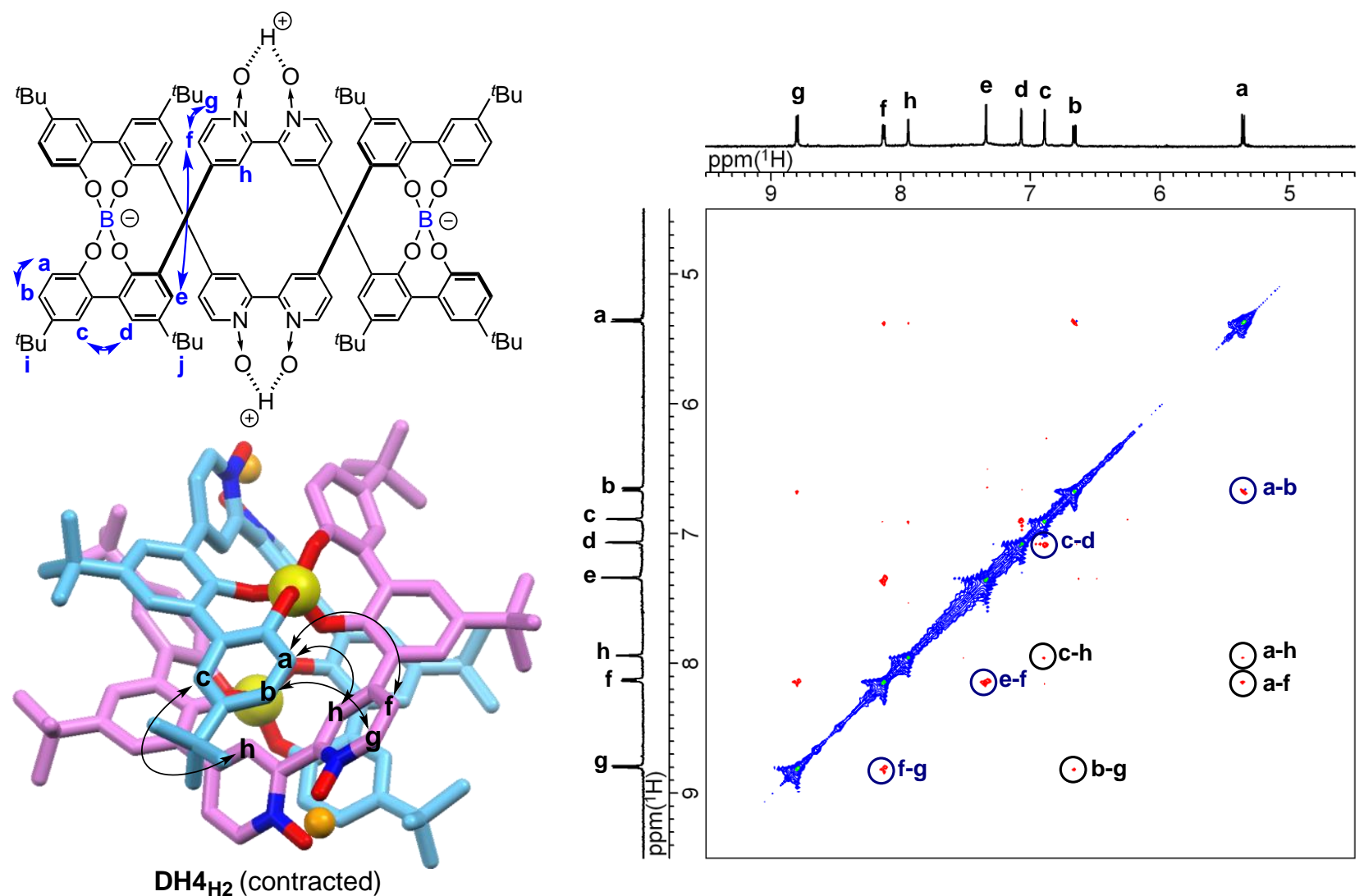

Figure S16. Partial NOESY spectrum of $\mathrm{DH}_{4} \mathrm{H}_{2}\left(500 \mathrm{MHz}, \mathrm{CD}_{3} \mathrm{CN}, 25^{\circ} \mathrm{C}, 1.2 \mathrm{mM}\right.$, mixing time $=$ $500 \mathrm{~ms}$ ). Interstrand NOE cross-peaks are indicated by arrows in the crystal structure of DH4 $\mathbf{H} 2$. 


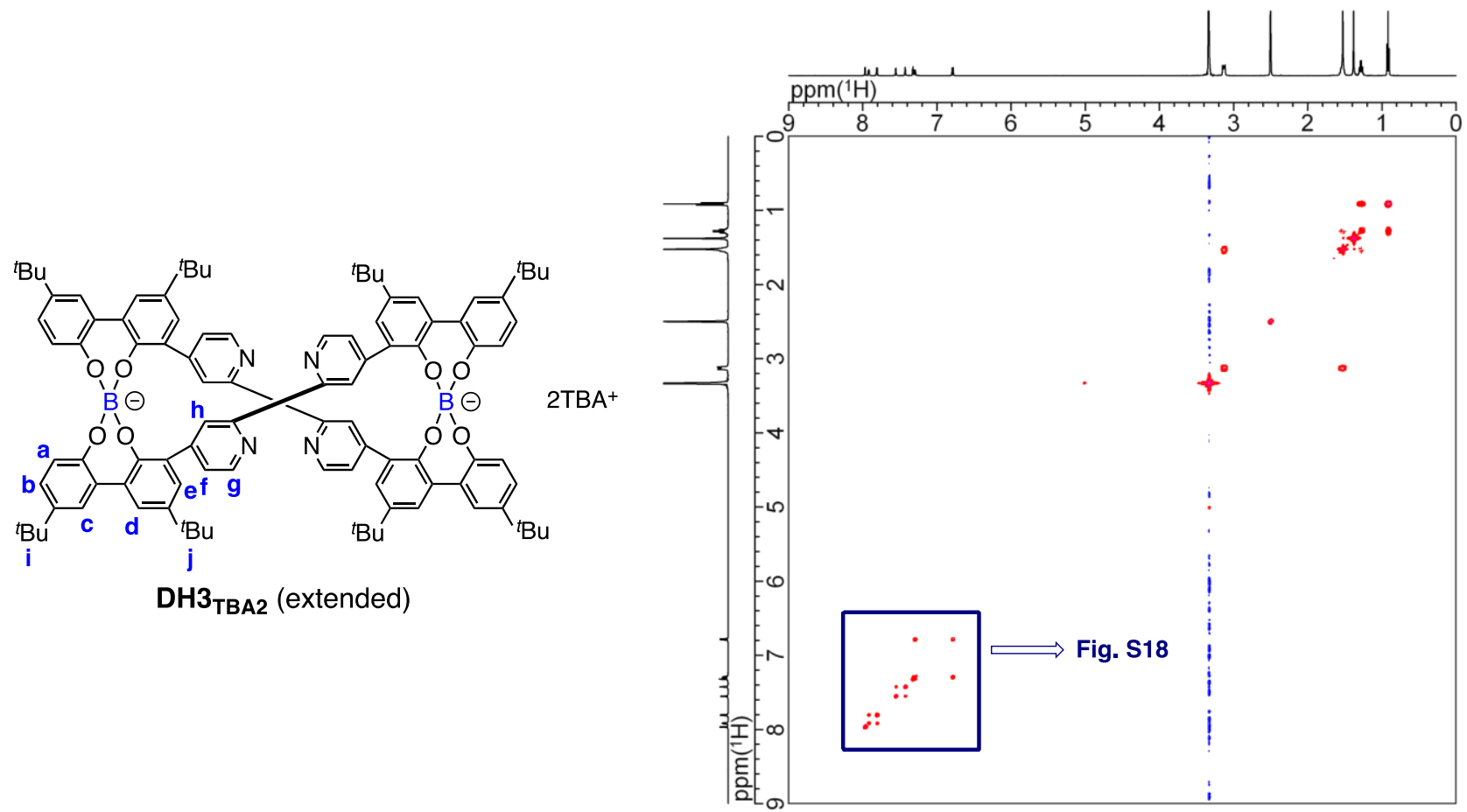

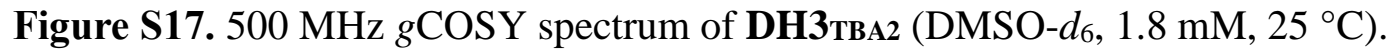
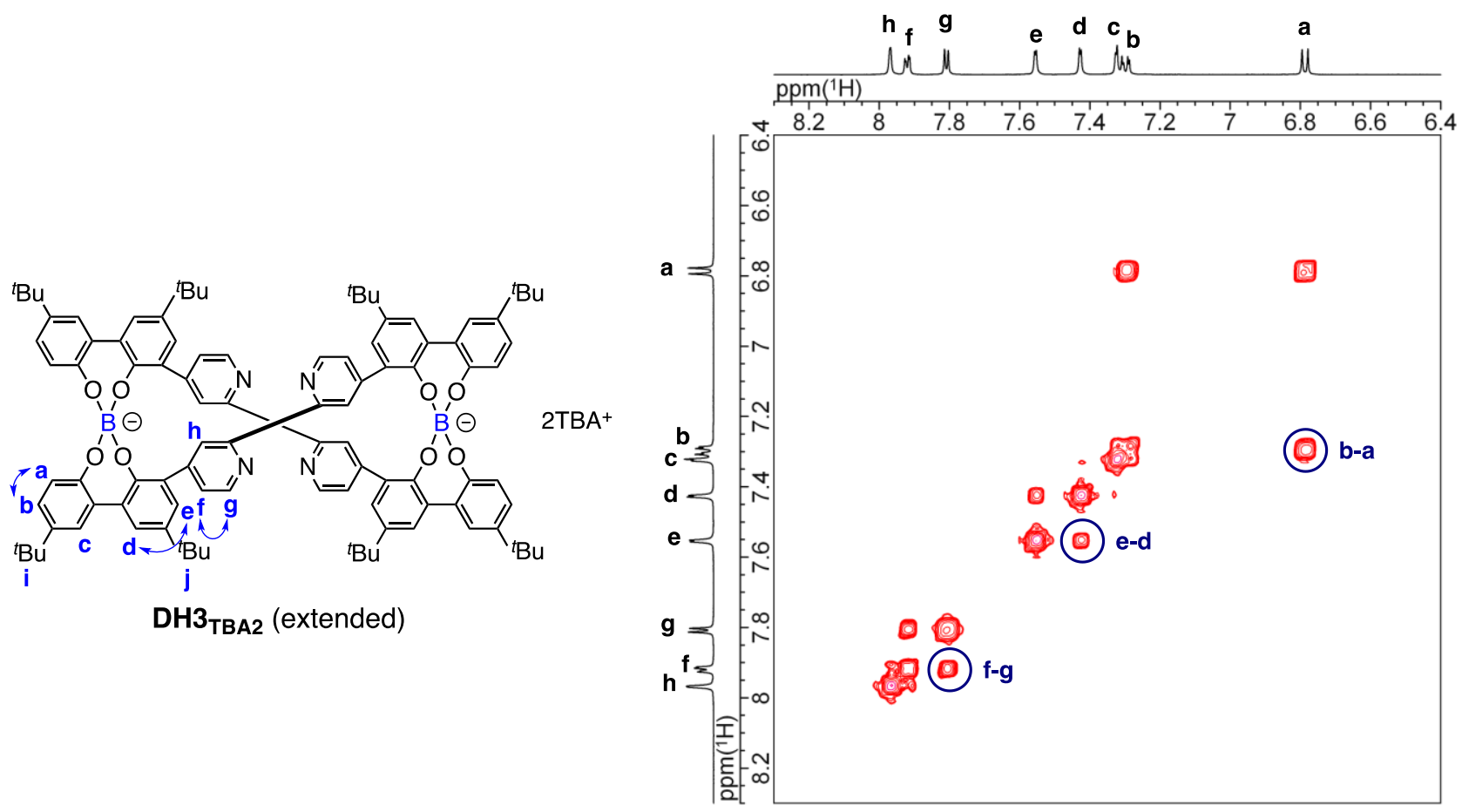

Figure S18. Partial $500 \mathrm{MHz} g \mathrm{COSY}$ spectrum of DH3 TBA2 $_{\text {(DMSO- }} d_{6}, 1.8 \mathrm{mM}, 25^{\circ} \mathrm{C}$ ). 

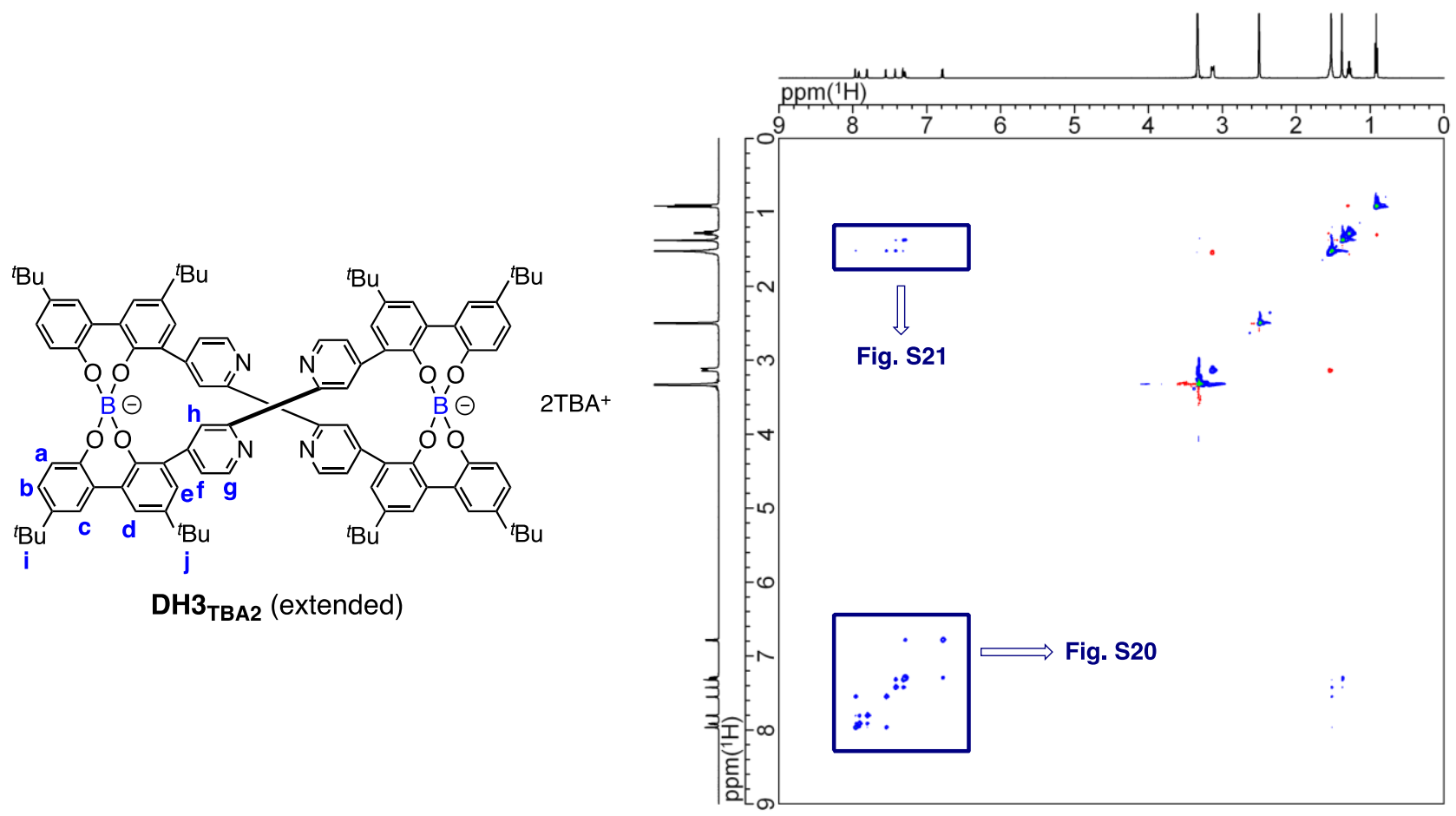

Figure S19. $500 \mathrm{MHz}$ NOESY spectrum of DH3 ${ }_{\mathrm{TBA} 2}\left(\mathrm{DMSO}-d_{6}, 1.8 \mathrm{mM}, 25^{\circ} \mathrm{C}\right.$, mixing time $=$ $500 \mathrm{~ms})$.
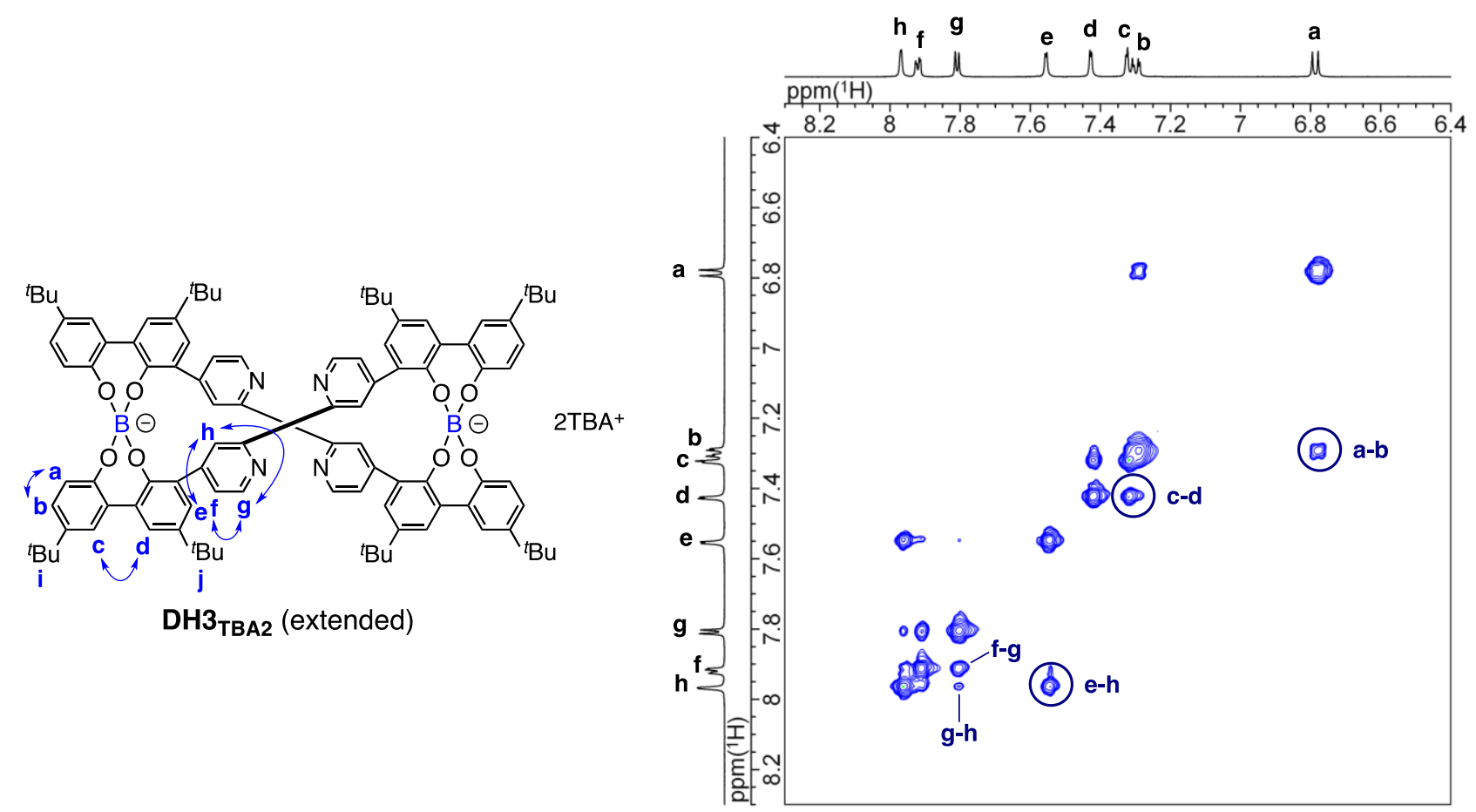

Figure S20. Partial $500 \mathrm{MHz}$ NOESY spectrum of DH3 TBA2 $_{\text {(DMSO- }} d_{6}, 1.8 \mathrm{mM}, 25^{\circ} \mathrm{C}$, mixing time $=500 \mathrm{~ms})$. 


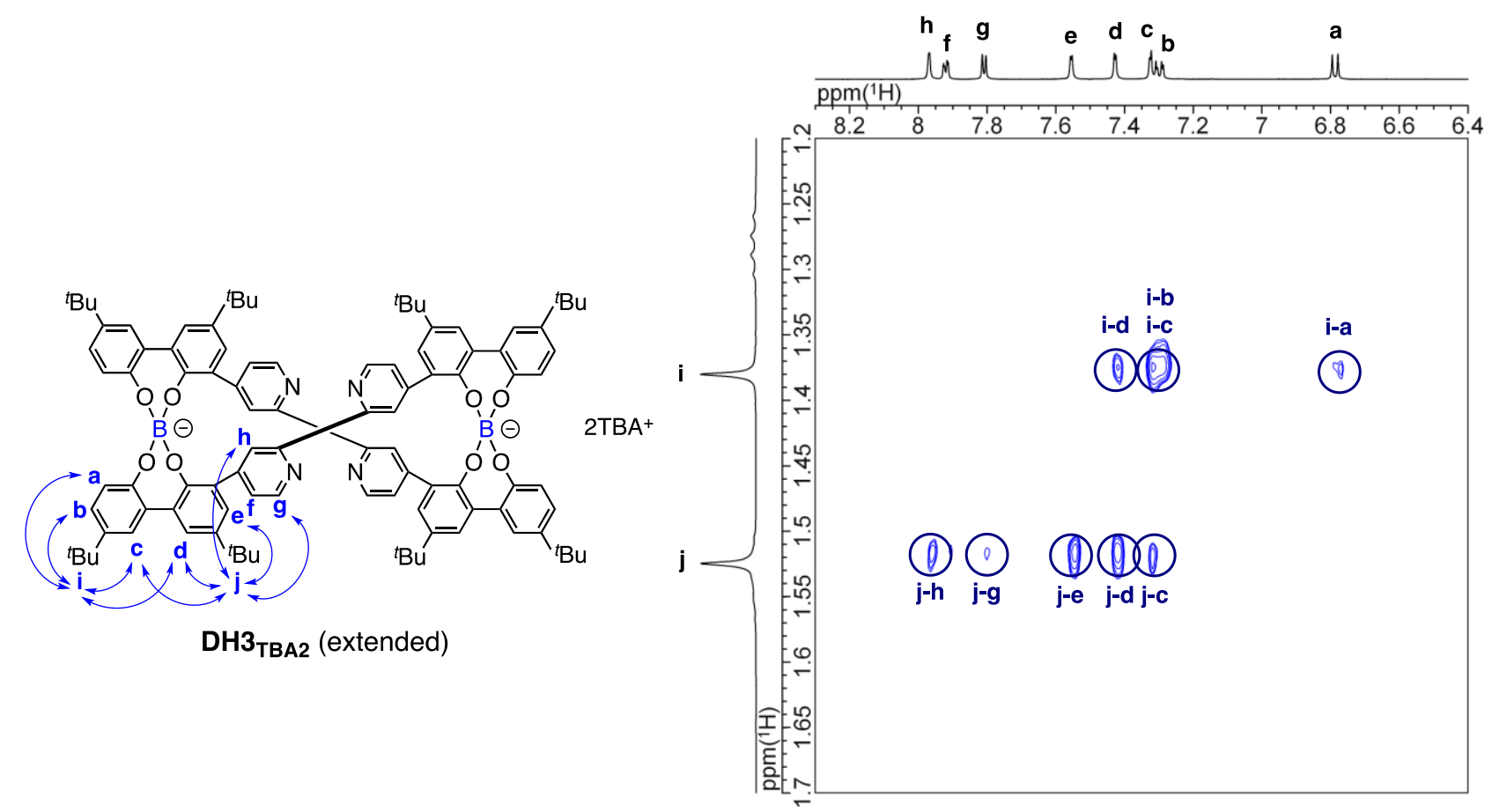

Figure S21. Partial $500 \mathrm{MHz}$ NOESY spectrum of DH3 time $=500 \mathrm{~ms}$ ). 


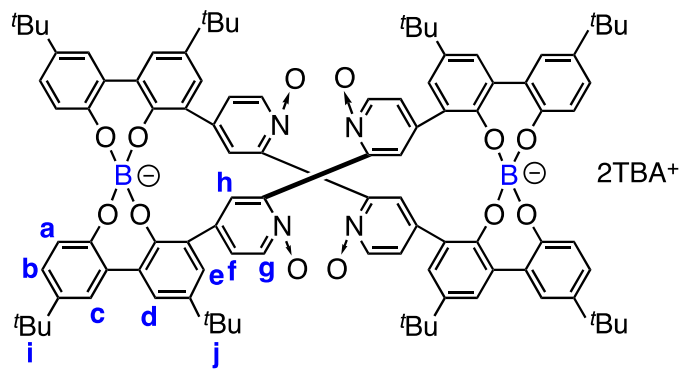

DH4 4 TBA2 (extended)

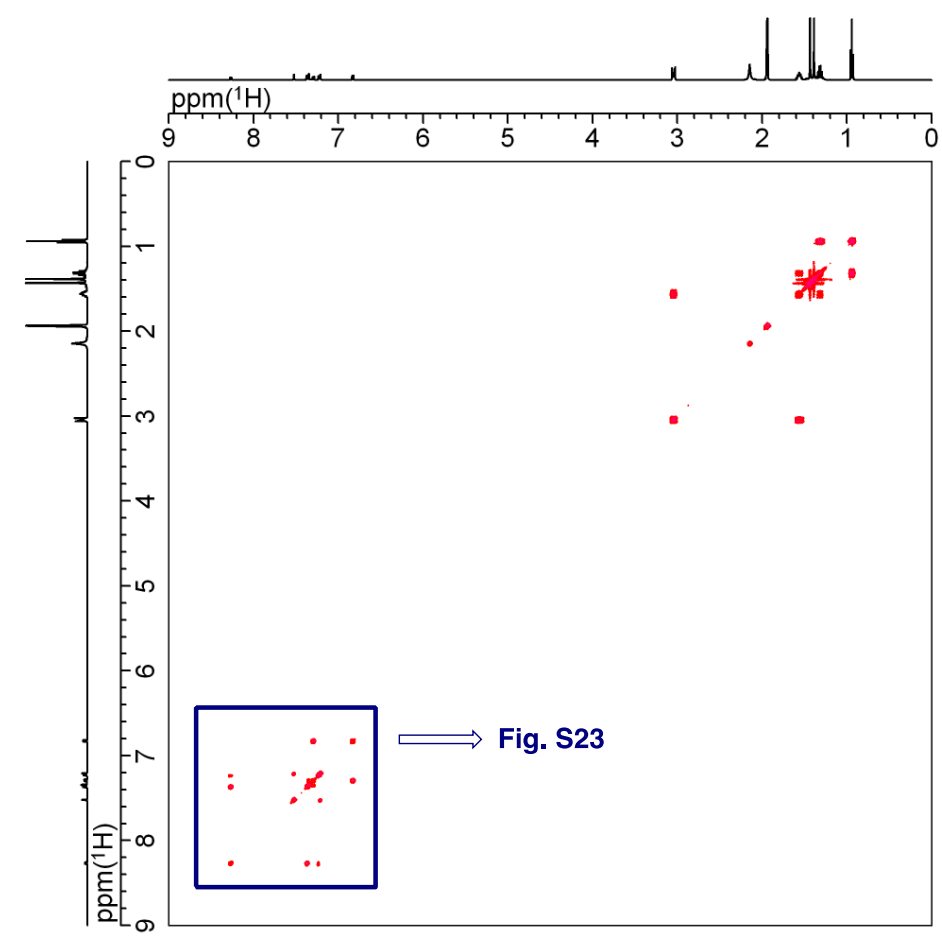

Figure S22. $g \mathrm{COSY}$ spectrum of DH4твA2 $\left(500 \mathrm{MHz}, \mathrm{CD}_{3} \mathrm{CN}, 25^{\circ} \mathrm{C}, 2.4 \mathrm{mM}\right)$.

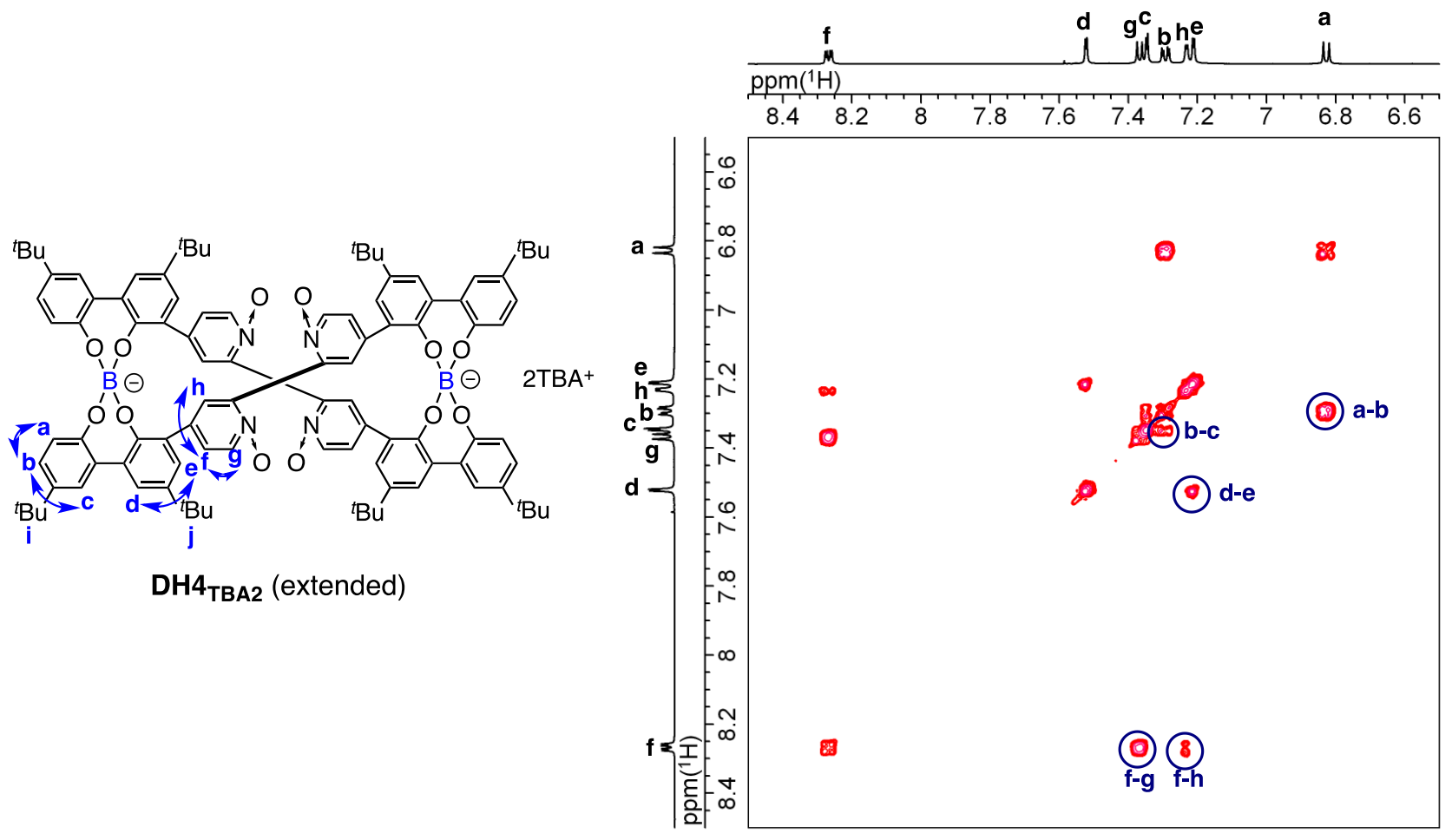

Figure S23. Partial $g \mathrm{COSY}$ spectrum of DH4 $\mathbf{T H A}_{\mathbf{T}}\left(500 \mathrm{MHz}, \mathrm{CD}_{3} \mathrm{CN}, 25^{\circ} \mathrm{C}, 2.4 \mathrm{mM}\right)$. 

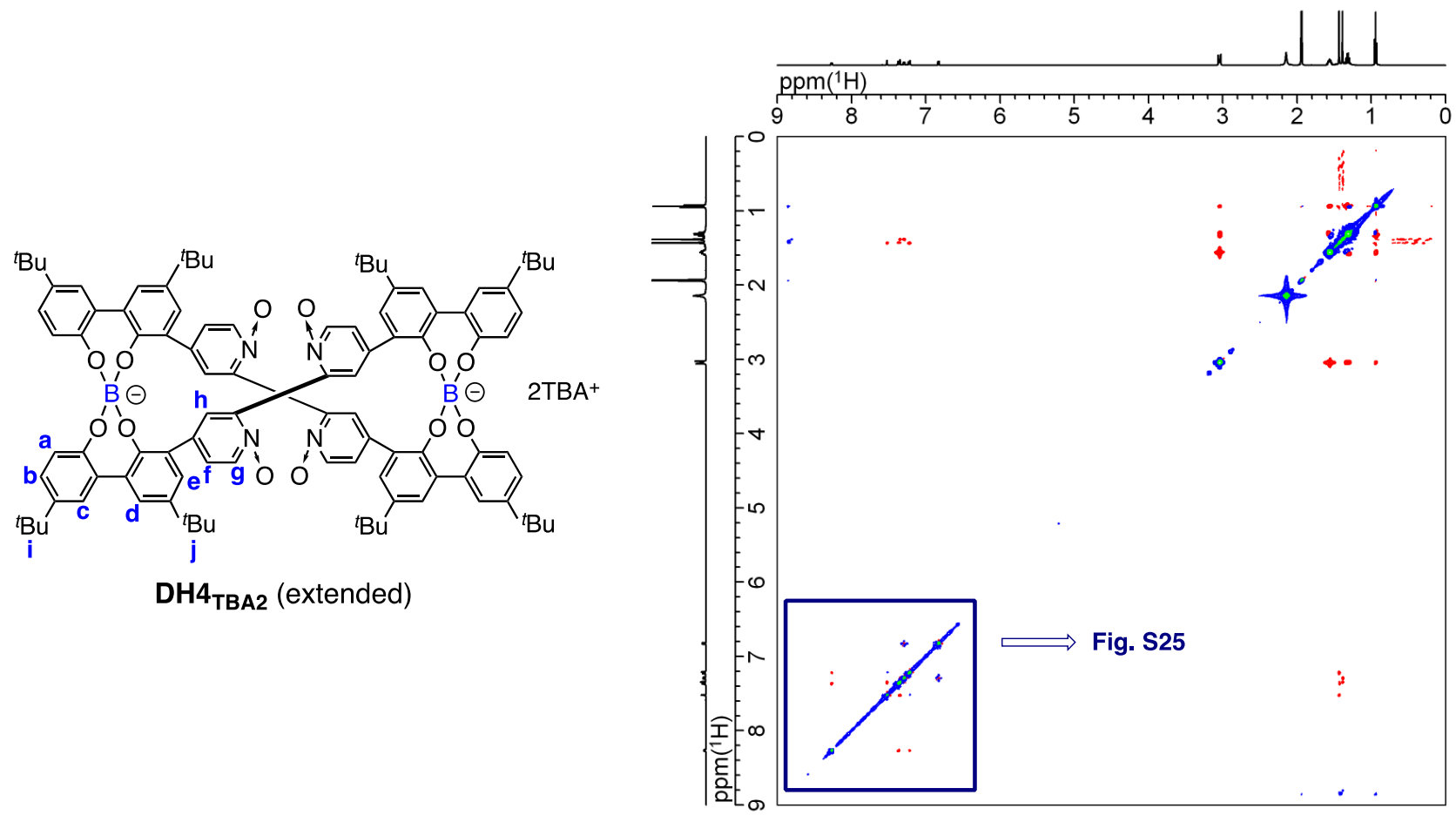

Figure S24. NOESY spectrum of $\mathbf{D H} 4_{\mathrm{TBA} 2}\left(500 \mathrm{MHz}, \mathrm{CD}_{3} \mathrm{CN}, 25^{\circ} \mathrm{C}, 2.4 \mathrm{mM}\right.$, mixing time $=500$ $\mathrm{ms})$.
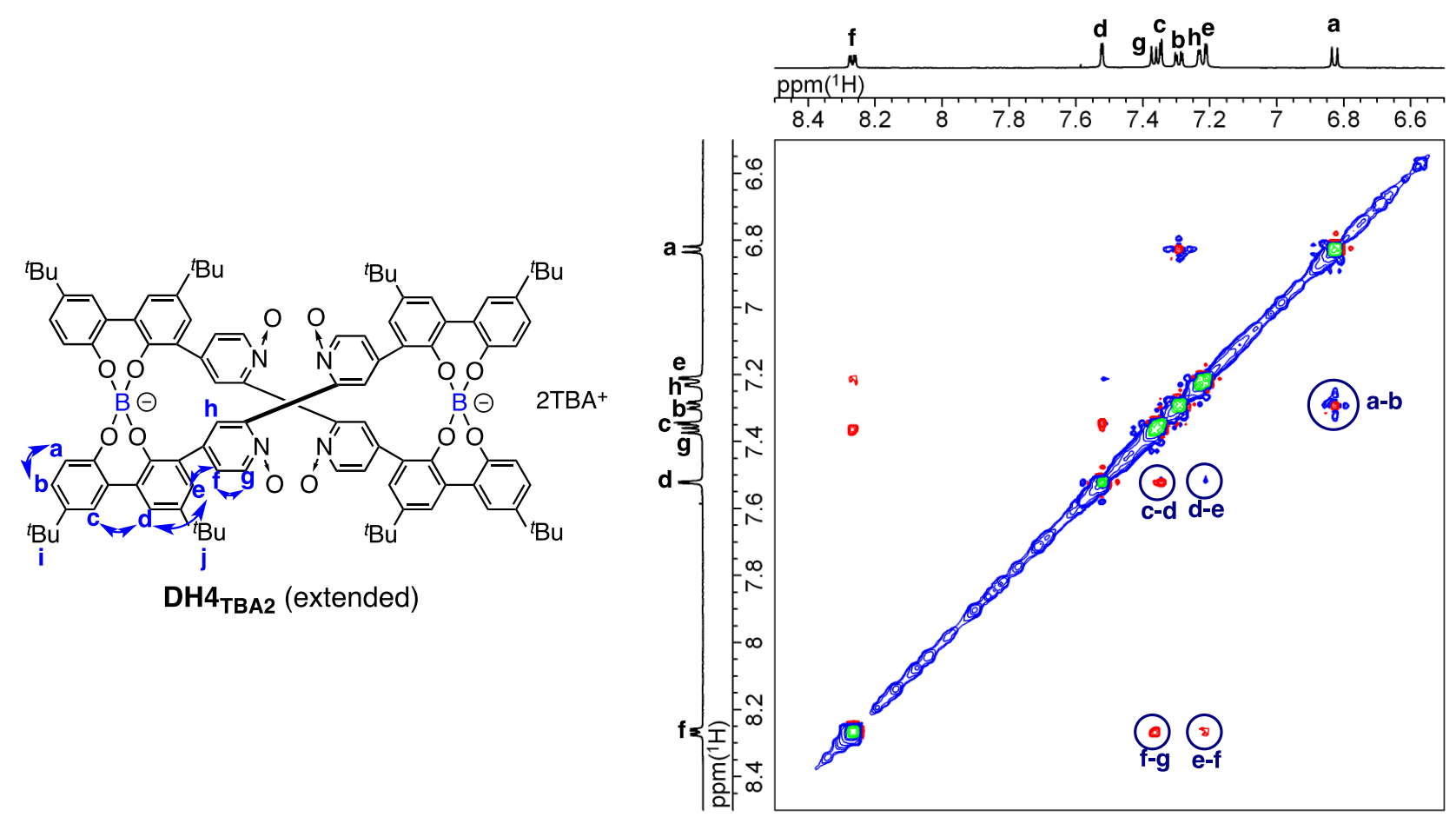

Figure S25. Partial NOESY spectrum of DH4тва2 $\left(500 \mathrm{MHz}, \mathrm{CD}_{3} \mathrm{CN}, 25^{\circ} \mathrm{C}, 2.4 \mathrm{mM}\right.$, mixing time $=500 \mathrm{~ms}$ ) 
optical resolution (diastereomeric salt formation)
$( \pm)-\mathrm{DH}_{\mathrm{Na} 2}$
$(+)-\mathrm{DH}_{[(S)-5] 2}$
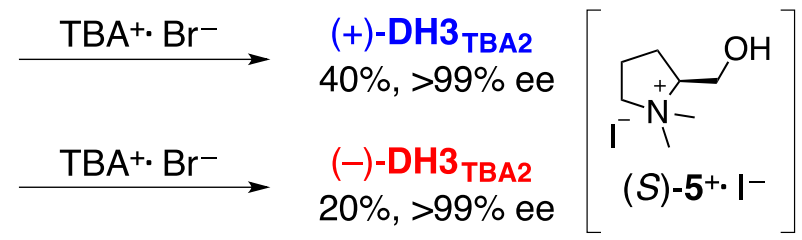

(i)

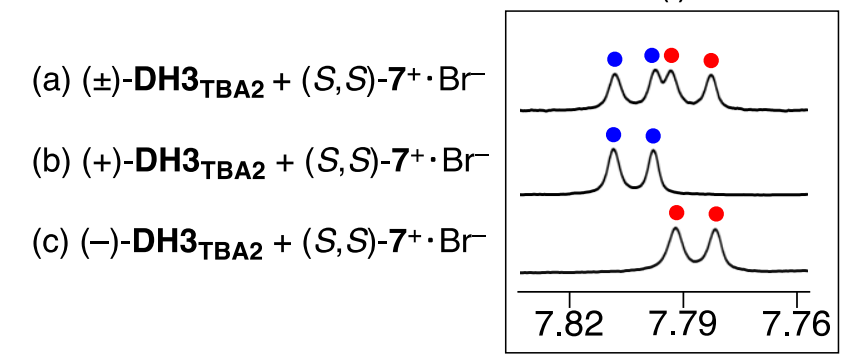

(ii)

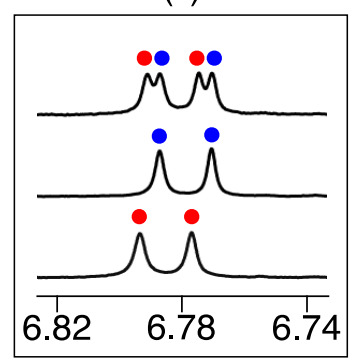

(iii)

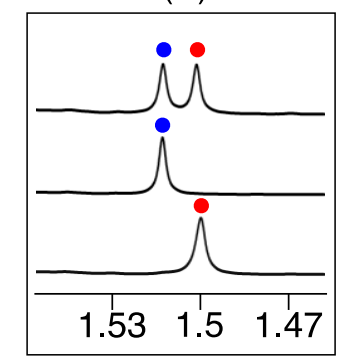

(i)

(ii)

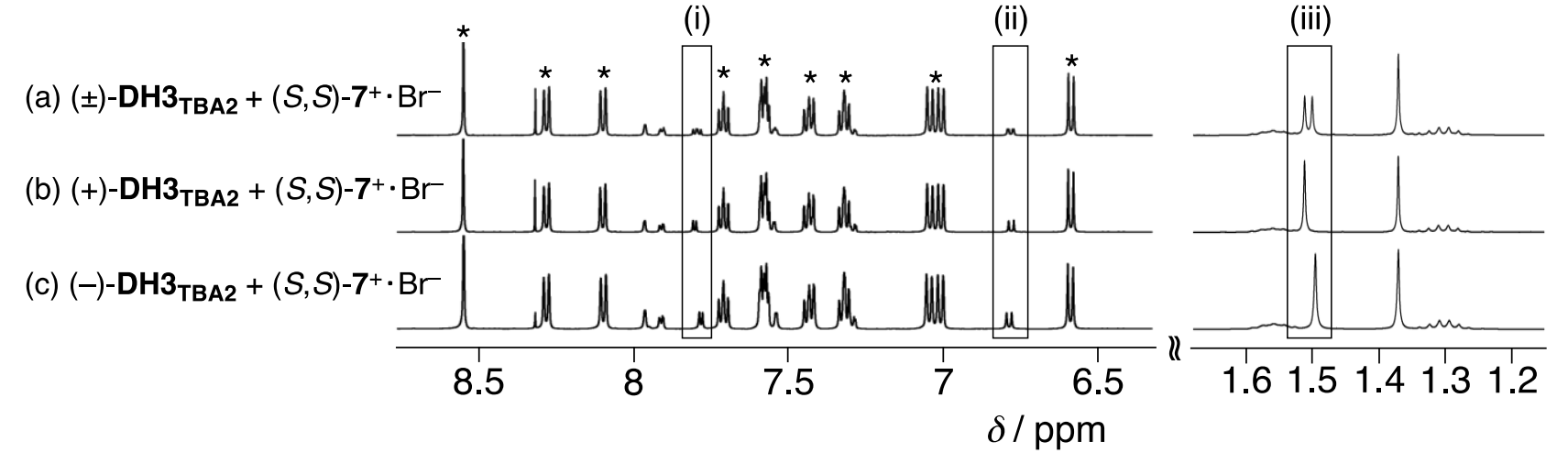

(iii)

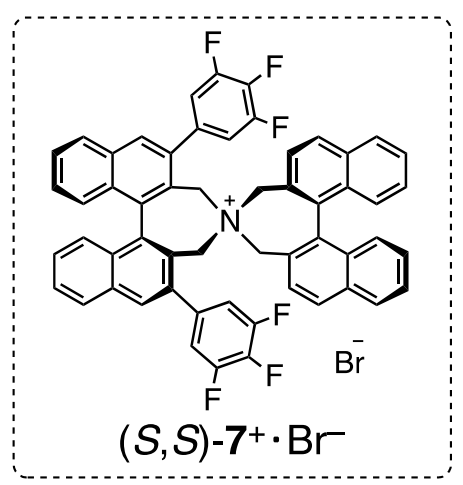

Figure S26. ${ }^{1} \mathrm{H}$ NMR spectra $\left(500 \mathrm{MHz}, \mathrm{DMSO}-d_{6}, 0.7 \mathrm{mM}, 25{ }^{\circ} \mathrm{C}\right)$ of mixtures of (a) $( \pm)$ DH3 ${ }_{\text {TBA2, }}$ (b) (+)-DH3 ${ }_{\text {TBA2, and (c) (-)-DH3 }}$ TBA2 with 10 equiv. of $(S, S)-7^{+} \cdot \mathrm{Br}^{-}$. The blue and red circles indicate the resonances due to the diastereomers. * denotes the protons from $(S, S)-7^{+}$. 
optical resolution (diastereomeric salt formation)

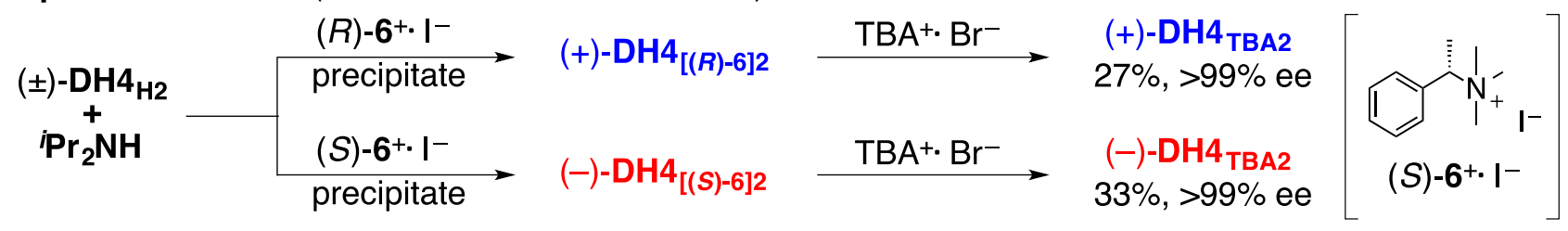

(i)

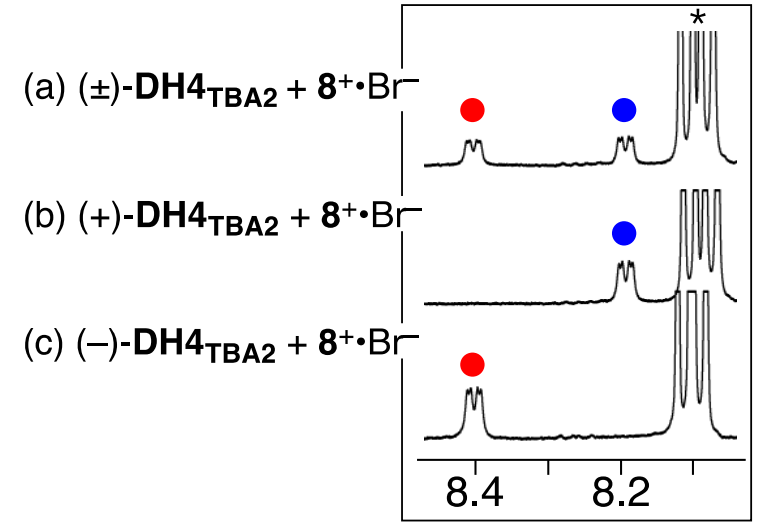

(ii)

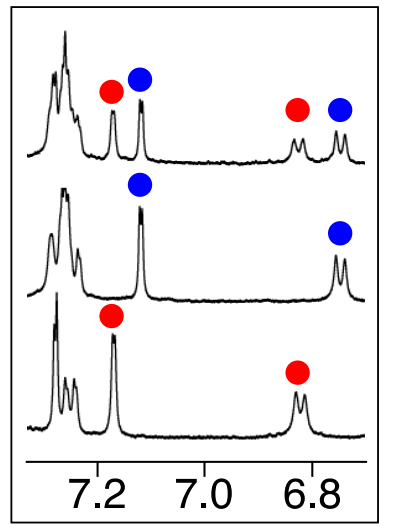

(i)

(ii)
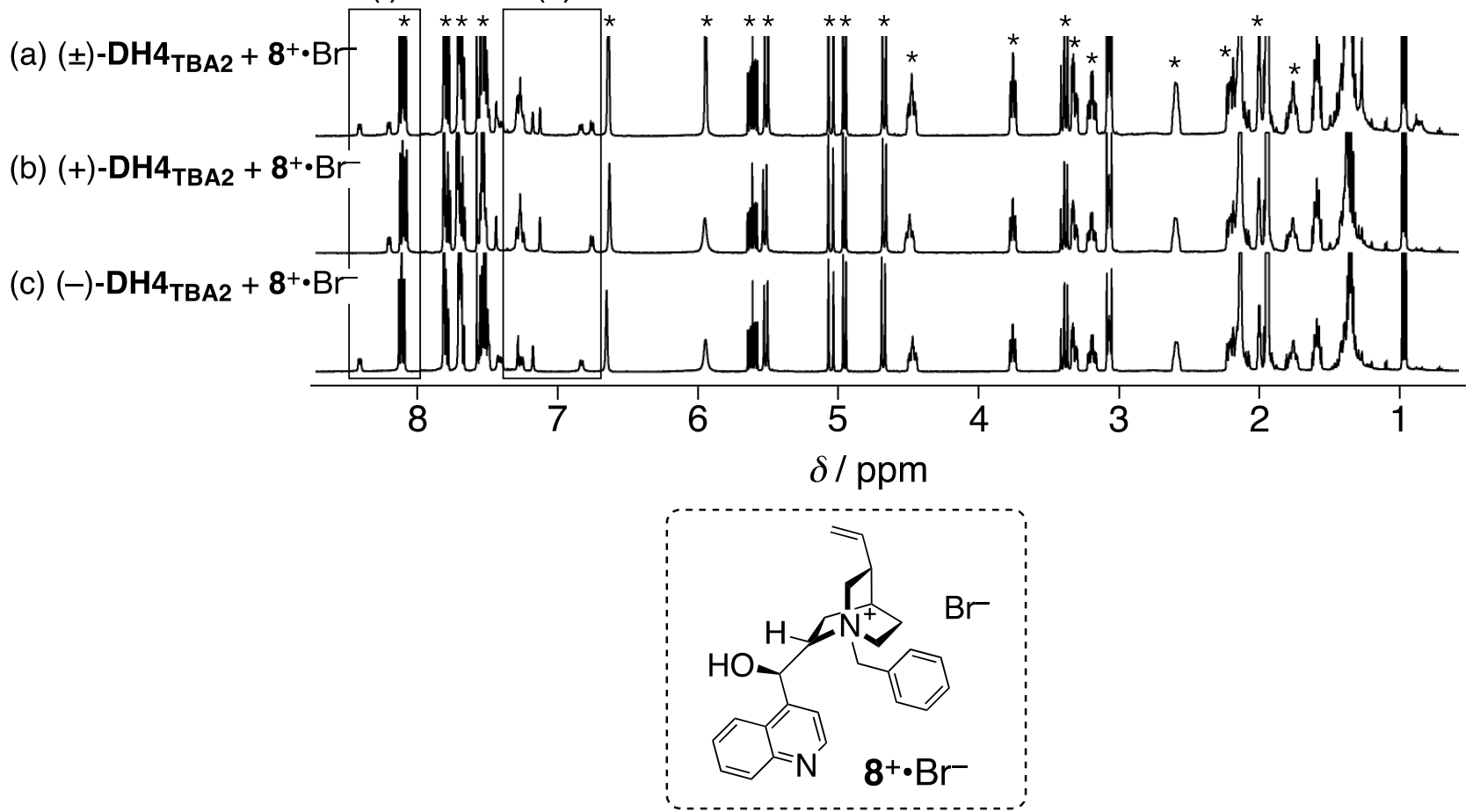

Figure S27. ${ }^{1} \mathrm{H}$ NMR spectra $\left(500 \mathrm{MHz}, \mathrm{CD}_{3} \mathrm{CN} / \mathrm{CDCl}_{3}(7 / 1, \mathrm{v} / \mathrm{v}), 25{ }^{\circ} \mathrm{C}\right)$ of mixtures of (a) ( \pm )DH4 $4_{\text {TBA2, }}$ (b) (+)-DH4 indicate the resonances due to the diastereomers. ${ }^{*}$ denotes the protons from $8^{+} \cdot \mathrm{Br}^{-}$. 


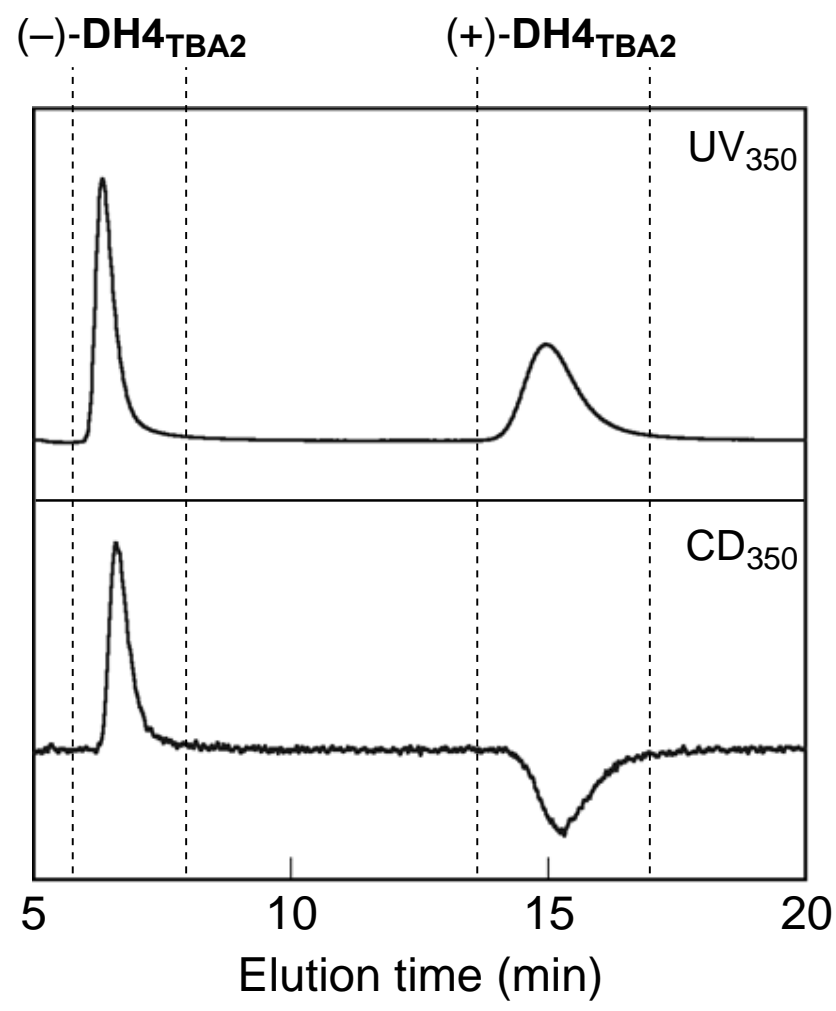

Figure S28. UV (upper) and CD (bottom) $(350 \mathrm{~nm})$ detected HPLC chromatograms of DH4 $\mathbf{H}$. HPLC conditions: column, CHIRALPAK IA (Daicel, 0.46 (i.d.) $\times 25 \mathrm{~cm}$ ); eluent, $n$ hexane $/ \mathrm{CH}_{2} \mathrm{Cl}_{2} / \mathrm{CH}_{3} \mathrm{CN}(60 / 40 / 5, \mathrm{v} / \mathrm{v})$ containing $\mathrm{TBA}^{+} \cdot \mathrm{Br}^{-}(0.5 \mathrm{mg} / \mathrm{mL})$; flow rate, $1.0 \mathrm{~mL} / \mathrm{min}$; column temperature, $25{ }^{\circ} \mathrm{C}$. The prefixes $(+)$ and $(-)$ denote the signs of the Cotton effect at 377 nm. The protons of DH4 $\mathbf{H}_{2}$ were exchanged during the HPLC resolution, giving the $(-)$ - and $(+)-$ DH4 $4_{\text {TBA2 }}$ enantiomers. 


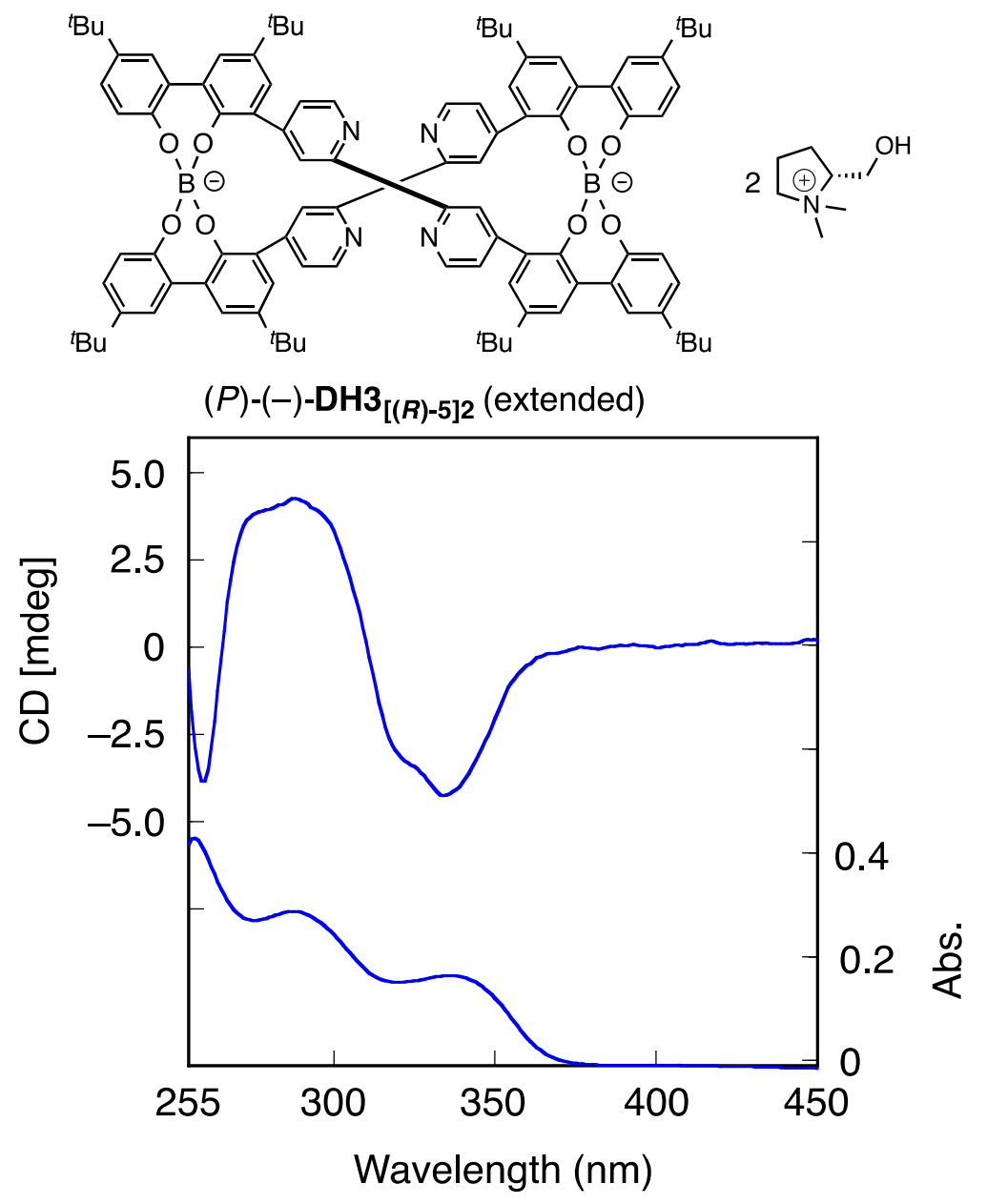

Figure S29. CD and absorption spectra (DMSO, $1 \mathrm{~mm}$ cell, ca. $25^{\circ} \mathrm{C}$ ) of the single crystal of the right-handed helical $(P)-(-)-\mathbf{D H} 3_{[(R)-5] 2}$ used for the X-ray diffraction measurements. 


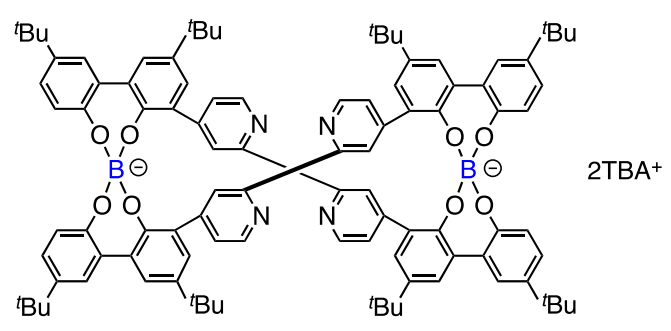

$(P)-(-)-$ DH3 $_{\text {TBA2 }}$ (extended)

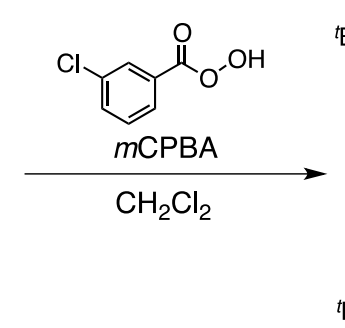

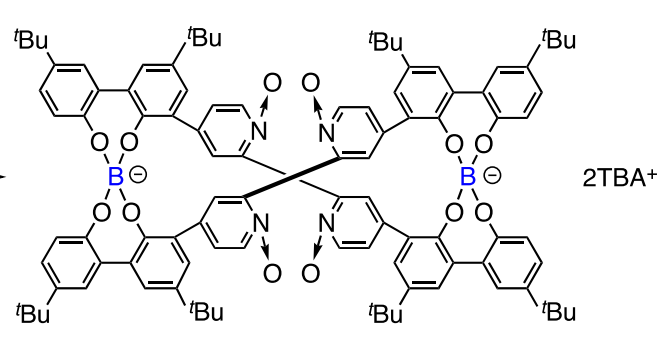

$(P)-(-)-$ DH4 $_{\text {TBA2 }}$ (extended)

a)

(i) $(P)-(-)-\mathrm{DH}_{\text {TBA2 }}$ aldu $+$

(ii) after reaction M. H

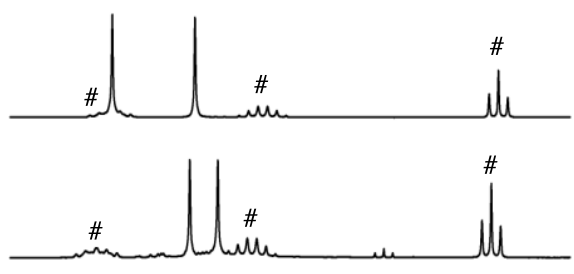

(iii) (P)-(-)-DH4 $4_{\text {TBA2 }}$
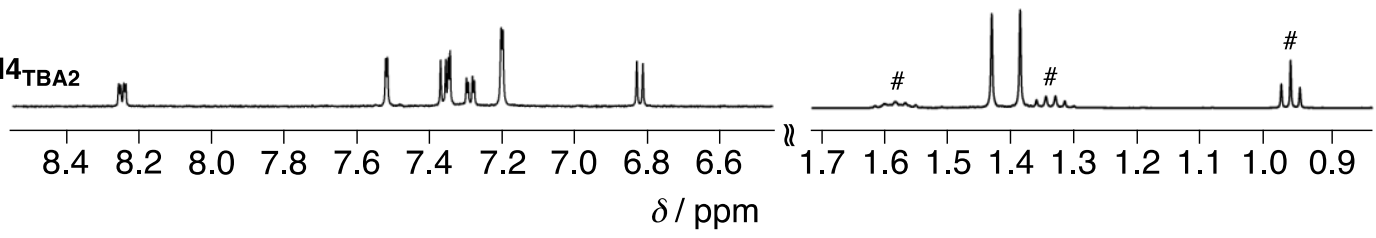

b)

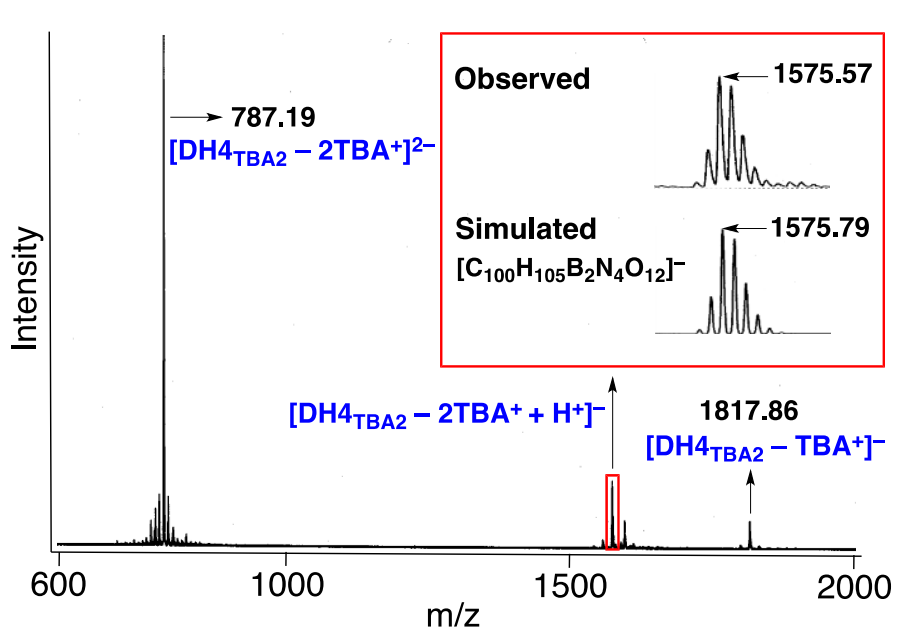

c)

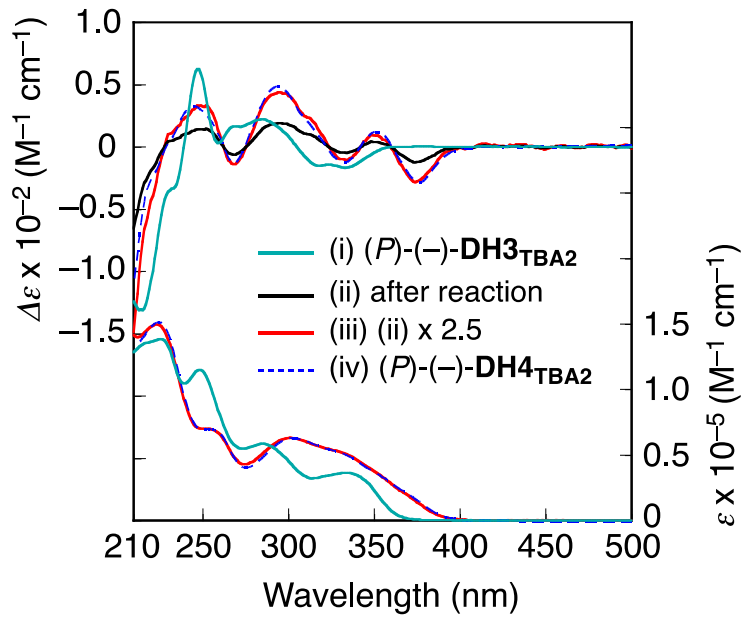

Figure S30. (a) Partial ${ }^{1} \mathrm{H}$ NMR spectra of enantiopure (P)-(-)-DH3 Tba2 (i), DH4 Tba2 obtained from the (-)-DH3 at room temperature. \# and * denote the protons from $\mathrm{TBA}^{+}$and residual $m \mathrm{CPBA}$, respectively. (b) Negative mode ESI mass spectrum of DH4 Tra2 obtained from the $(P)-(-)-\mathbf{D H} \mathbf{3}_{\mathbf{T B A} 2}$ reacted with $m$ CPBA. (c) CD (upper) and absorption (bottom) spectra of enantiopure (P)-(-)-DH3 TBA2 (i), DH4 4 TBA2 obtained from the $(P)-(-)$-DH3 ${ }_{\text {TBA2 }}$ after reaction with $m$ CPBA (ii), expanded CD of (ii) by 2.5 (iii), and enantiopure (-)- $\mathbf{D H 4} \mathbf{T B A 2}_{2}$ (iv) in $\mathrm{CH}_{3} \mathrm{CN}$ at room temperature. The ee value of the helicate DH4 TBa2 was estimated to be ca. 40\% ((-) rich) based on the CD intensities at $294 \mathrm{~nm}$ for (ii) and (iv). 

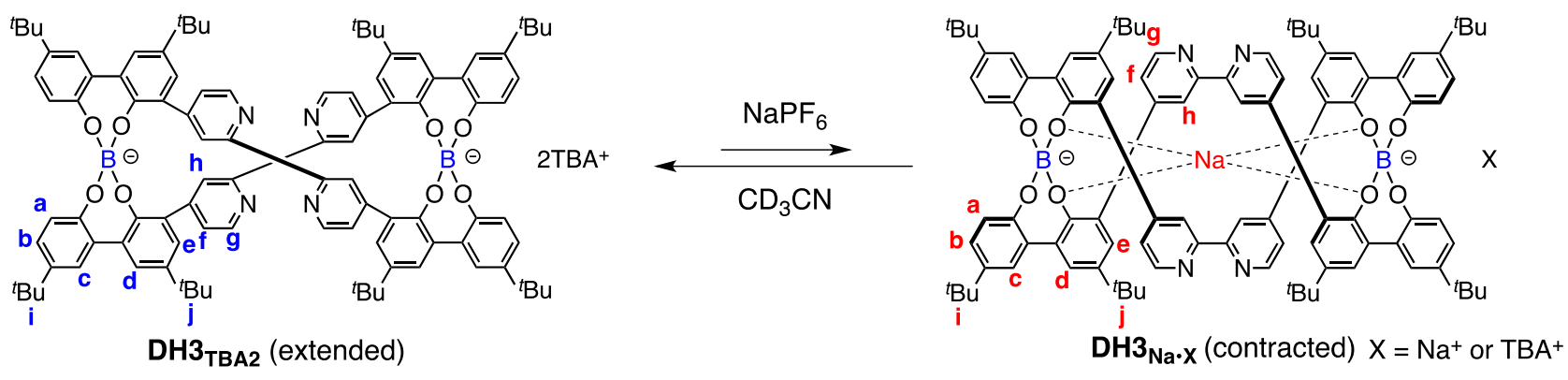

(a) $\mathrm{DH}_{\mathrm{TBA} 2}$
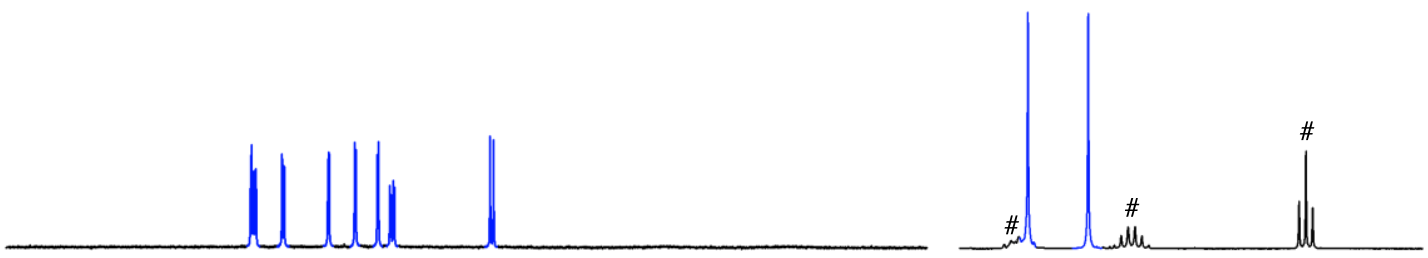

(b) (a) $+\mathrm{NaPF}_{6}$ (1.0 equiv)
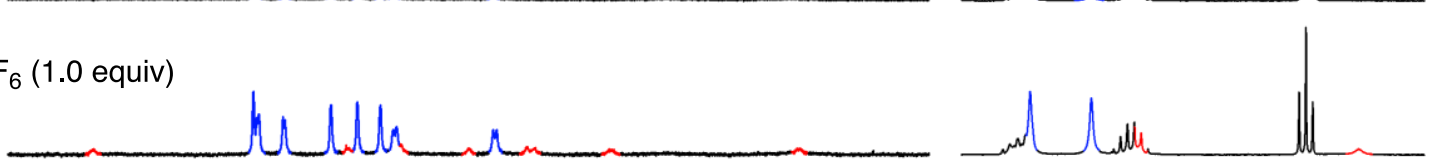

(c) (a) $+\mathrm{NaPF}_{6}$ (3.0 equiv)

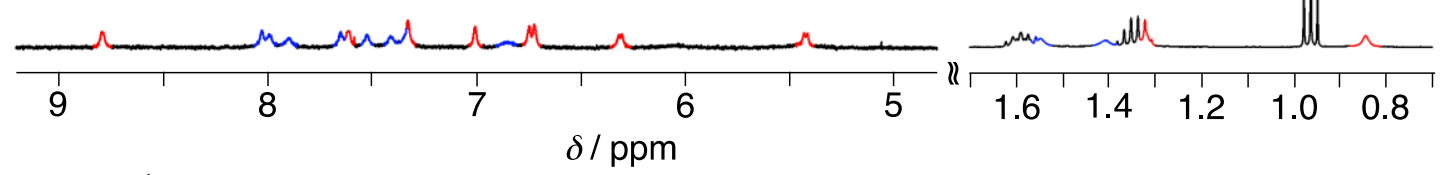

Figure S31. Partial ${ }^{1} \mathrm{H}$ NMR spectra $\left(500 \mathrm{MHz}, \mathrm{CD}_{3} \mathrm{CN}, 0.5 \mathrm{mM}\right.$, rt) of DH3 TBA2 in the absence (a) and presence $\left(1.0\right.$ (b) and 3.0 equiv (c)) of $\mathrm{NaPF}_{6}$. $\#$ denotes the protons from $\mathrm{TBA}^{+}$. DH3 $\mathbf{N a} \cdot \mathbf{X}(\mathrm{X}=$ $\mathrm{Na}^{+}$or $\mathrm{TBA}^{+}$) was partially precipitated. 

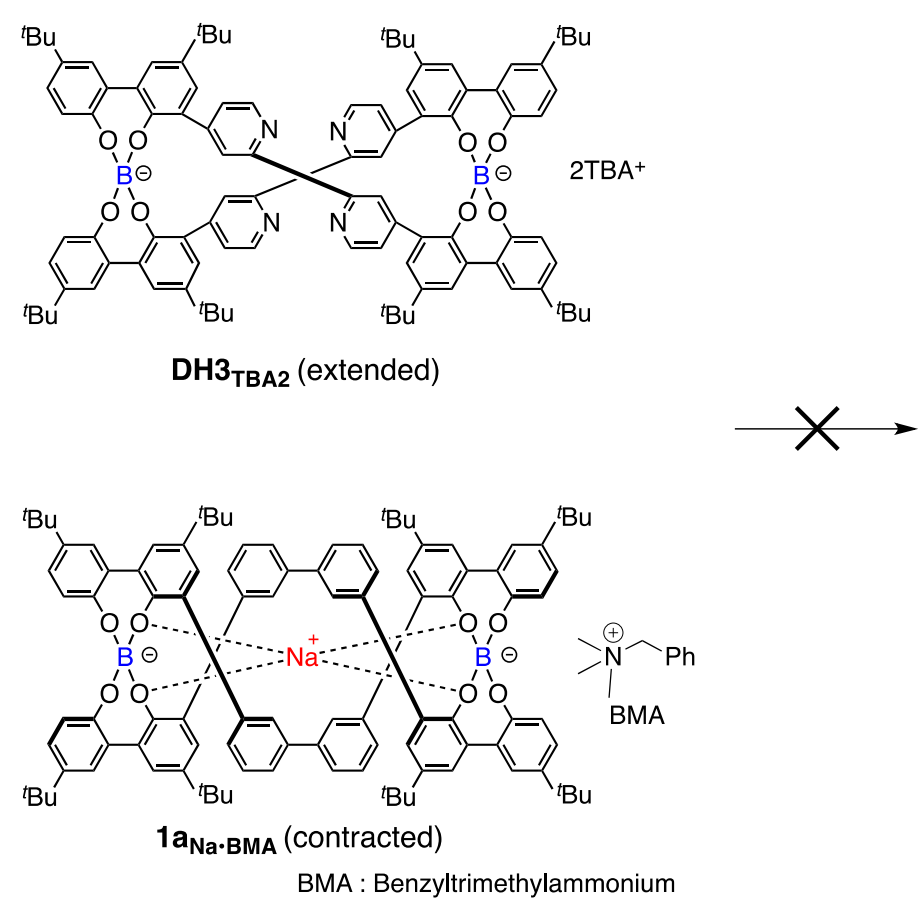

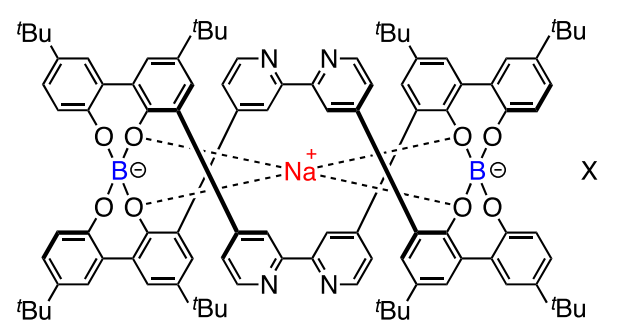

$\mathrm{DH}_{\mathrm{Na} 2}$ (contracted)

$\mathrm{X}=\mathrm{TBA}^{+}$or $\mathrm{BMA}^{+}$

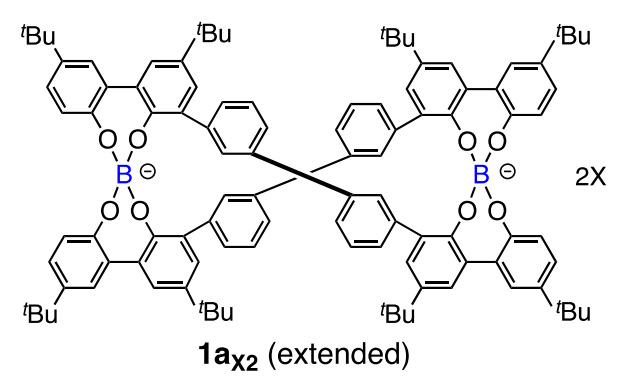

$1 a_{X 2}$ (extended)

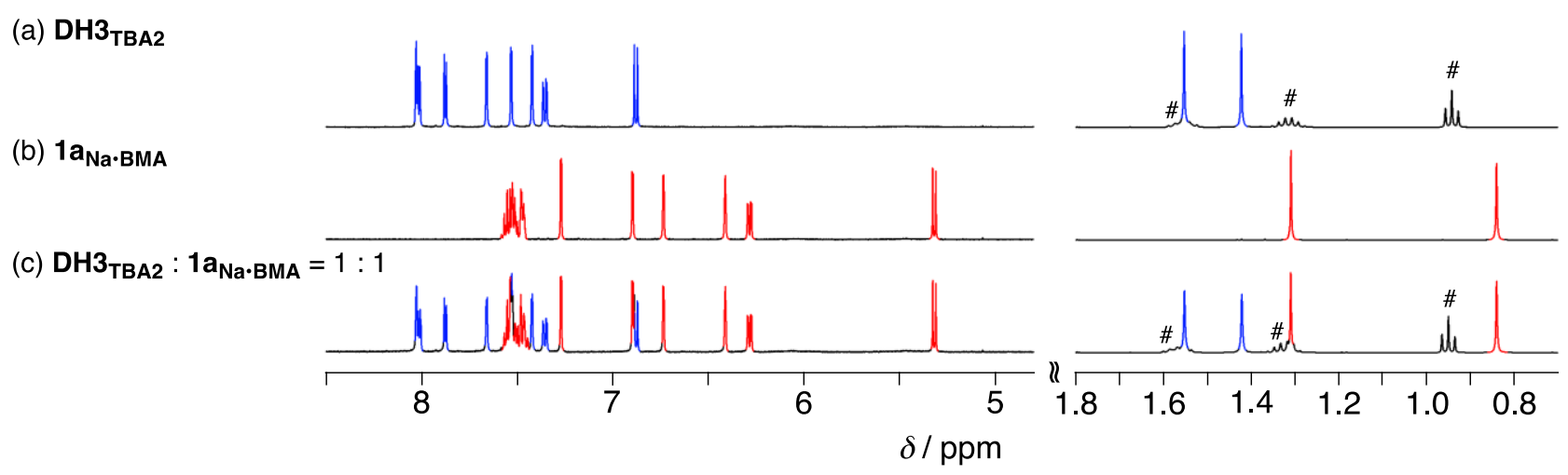

Figure S32. Partial ${ }^{1} \mathrm{H}$ NMR spectra $\left(500 \mathrm{MHz}, \mathrm{CD}_{3} \mathrm{CN}\right.$, rt) of DH3 $\mathbf{T}_{\text {TBA2 }}$ (a), 1ana-BMA (BMA = benzyltrimethylammonium) (b), and a 1:1 mixture of DH3 protons from $\mathrm{TBA}^{+}$. 


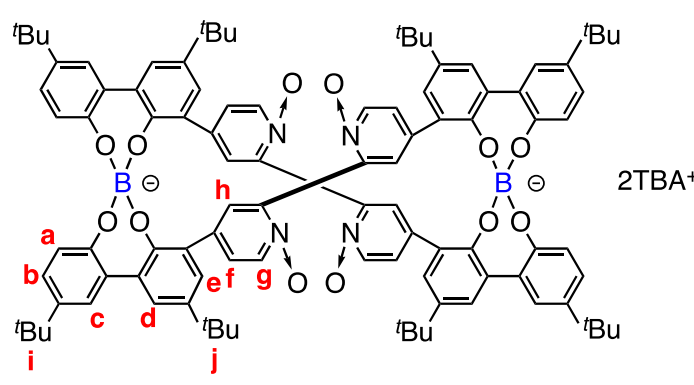

DH4
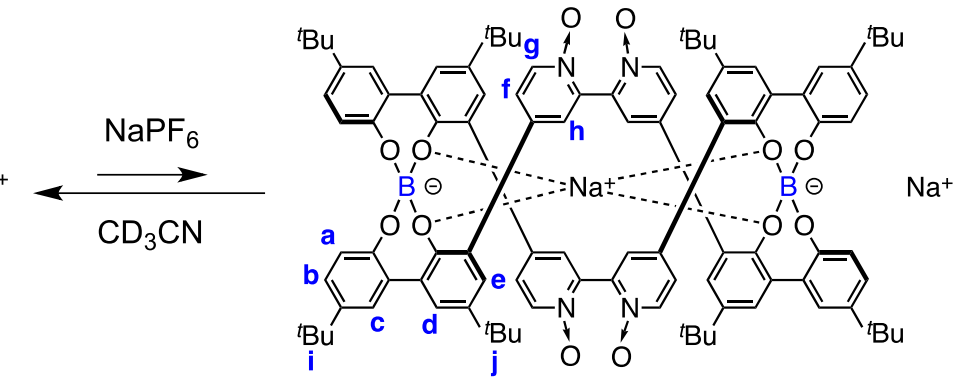

$\mathrm{DH}_{\mathrm{Na} 2}$ (contracted)

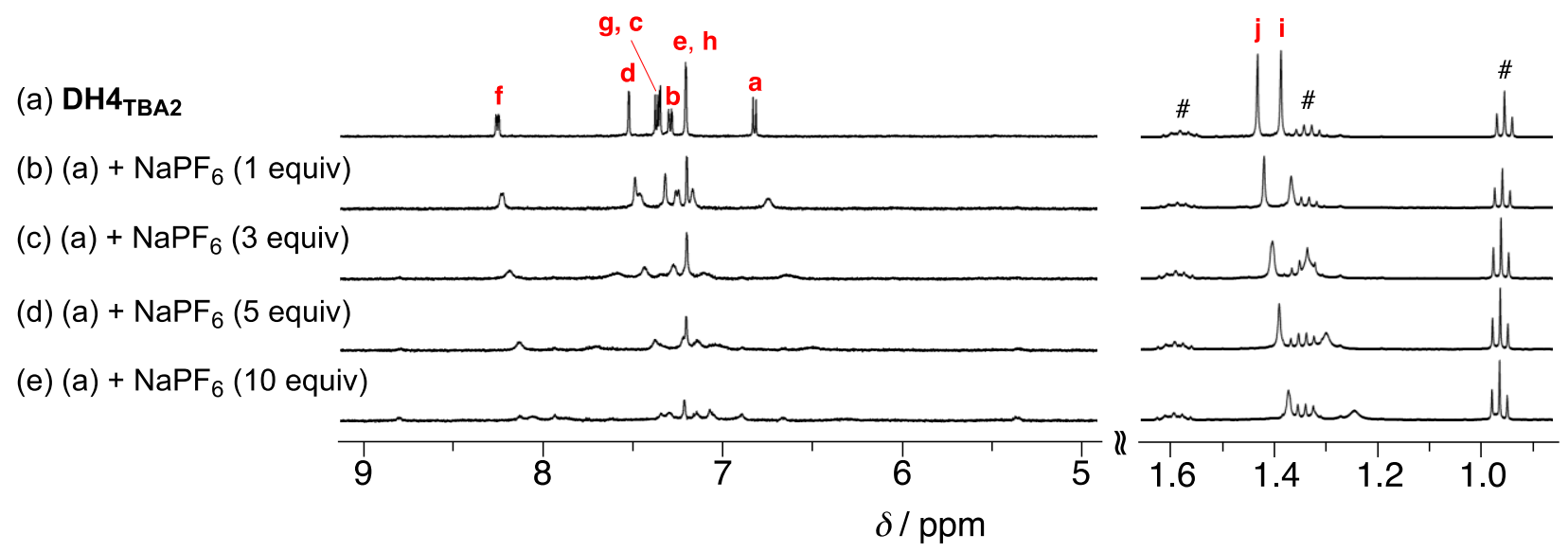

Figure S33. Partial ${ }^{1} \mathrm{H}$ NMR spectra $\left(500 \mathrm{MHz}, \mathrm{CD}_{3} \mathrm{CN}, 25{ }^{\circ} \mathrm{C}, 0.5 \mathrm{mM}\right)$ of $\mathbf{D H}_{\mathrm{TBA} 2}$ in the presence of $\mathrm{NaPF}_{6}\left(0-10\right.$ equiv). $\#$ denotes the protons from $\mathrm{TBA}^{+}$.

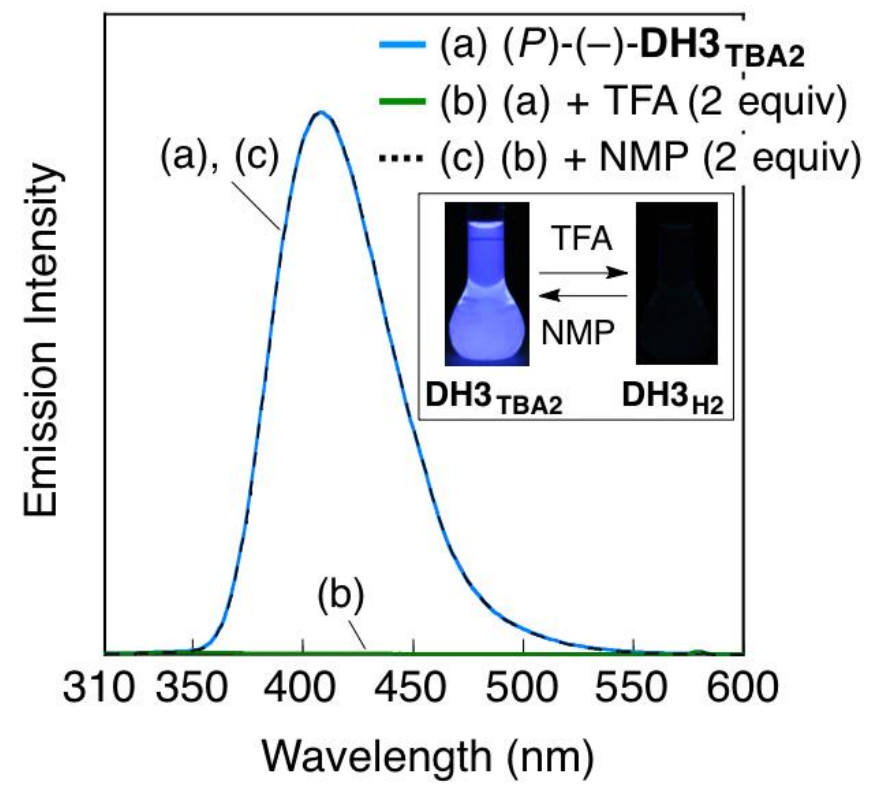

Figure S34. Fluorescence spectra (DMSO, $10 \mu \mathrm{M}$, ca. $25^{\circ} \mathrm{C}, \lambda_{\mathrm{ex}}=289 \mathrm{~nm}$ ) of (a) $(P)-(-)$-DH3 TBA2, (b) (a) + TFA (2 equiv), and (c) (b) + NMP (2 equiv). (Inset) Photographs of a DMSO solution of $(P)-(-)$-DH3 ${ }_{\text {TBA2 }}(10 \mu \mathrm{M})$ before and after the addition of TFA (2 equiv) under irradiation at 365 nm. 

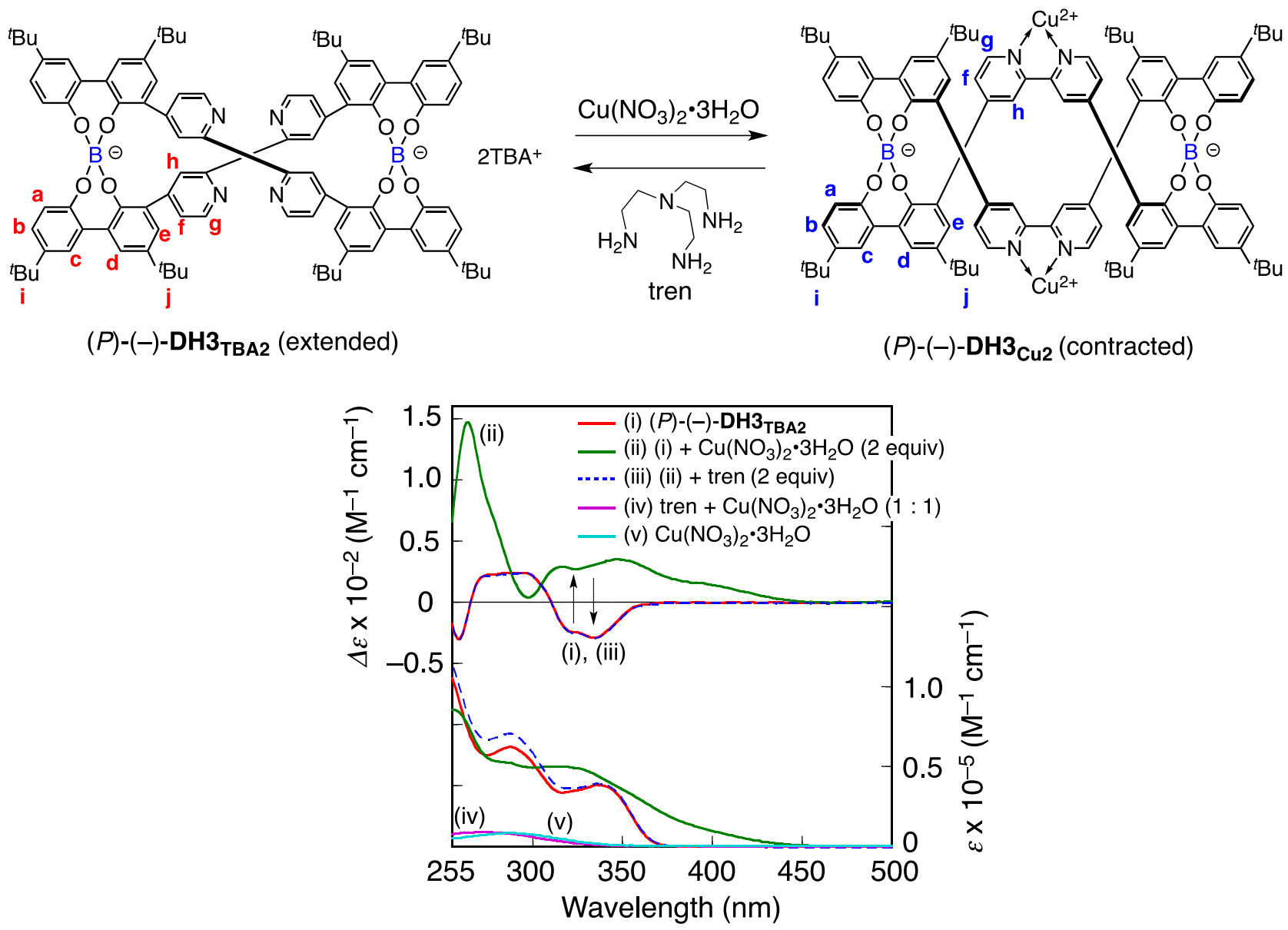

Figure S35. (a) CD (upper) and absorption (bottom) spectra of (P)-(-)-DH3 TBA2 (i), (i) with $\mathrm{Cu}\left(\mathrm{NO}_{3}\right)_{2} \cdot 3 \mathrm{H}_{2} \mathrm{O}$ (2 equiv) (ii), and (ii) with tren (2 equiv) (iii) in DMSO at room temperature. [(P)$(-)-$ DH3 $\left._{\text {TBA2 }}\right]=9.7 \times 10^{-5} \mathrm{M}$. Absorption spectra of a 1:1 complex of $\mathrm{Cu}(\mathrm{II})$ and tren (iv) and $\mathrm{Cu}\left(\mathrm{NO}_{3}\right)_{2} \cdot 3 \mathrm{H}_{2} \mathrm{O}$ alone (v) are also shown. 


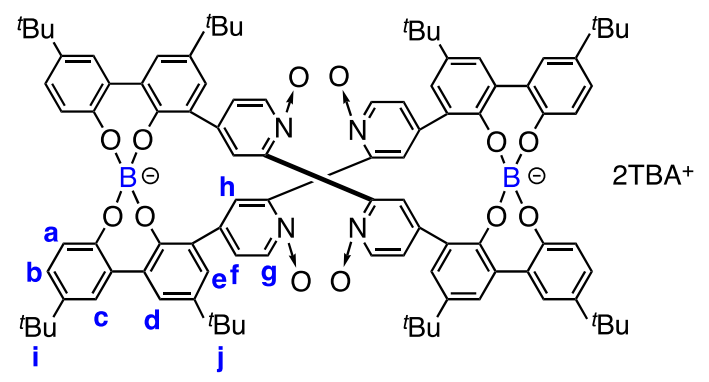

$(P)-(-)-$ DH4 $_{\text {TBA2 }}$ (extended)
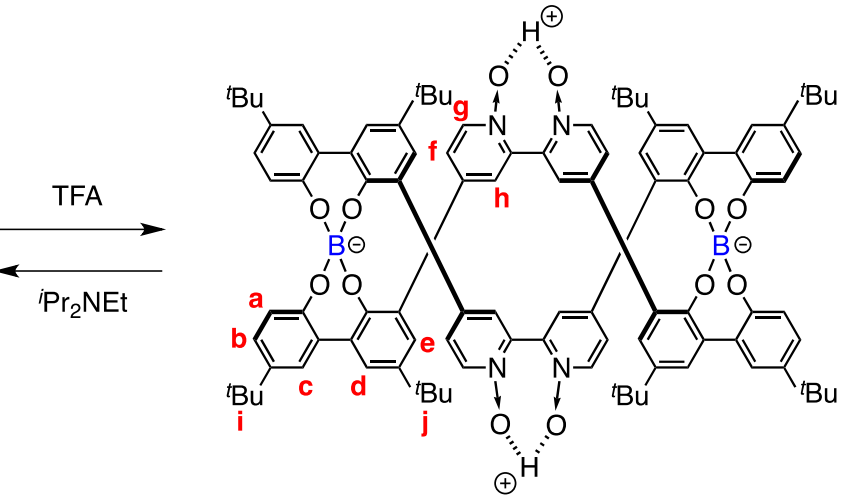

$(P)-(-)-\mathrm{DH}_{\mathrm{H} 2}$ (contracted)

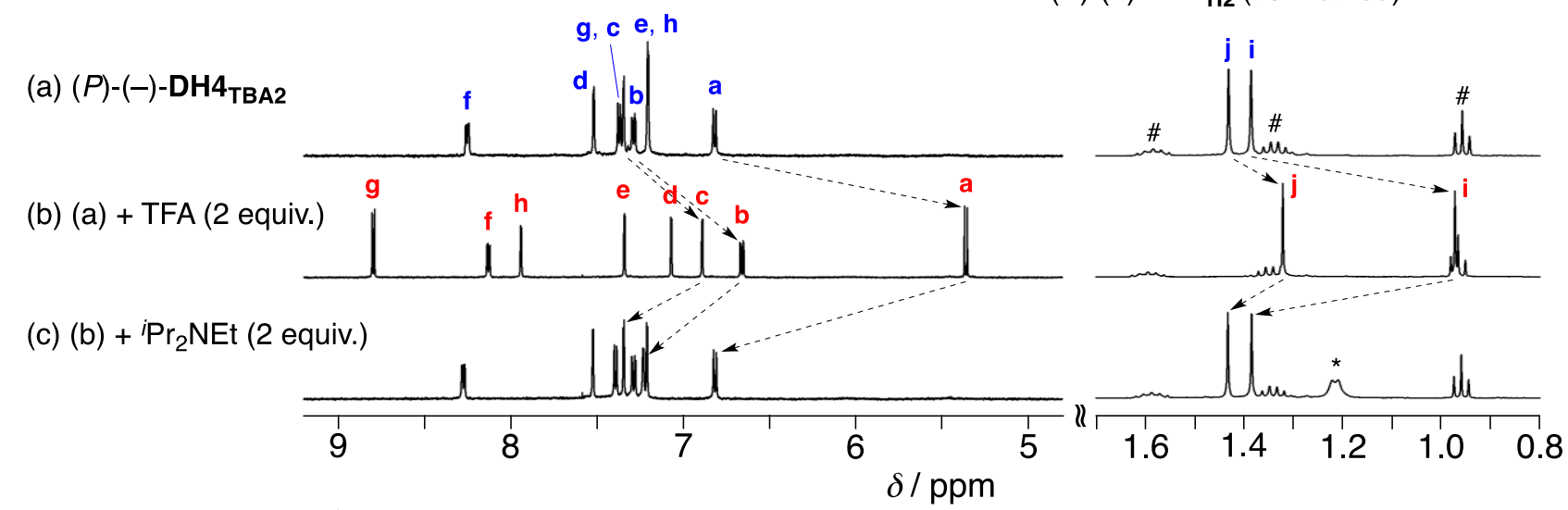

Figure S36. Partial ${ }^{1} \mathrm{H}$ NMR spectra $\left(500 \mathrm{MHz}, \mathrm{CD}_{3} \mathrm{CN}, 0.6 \mathrm{mM}, 25{ }^{\circ} \mathrm{C}\right)$ of (a) $(P)-(-)-\mathbf{D H} 4 \mathrm{TBA2}$, (b) (a) + TFA ( 2 equiv), and (c) (b) $+{ }^{i} \operatorname{Pr}_{2} \mathrm{NEt}$ (2 equiv). \# and $*$ denote the protons from $\mathrm{TBA}^{+}$and protonated ${ }^{i} \mathrm{Pr}_{2} \mathrm{NEt}$, respectively. 

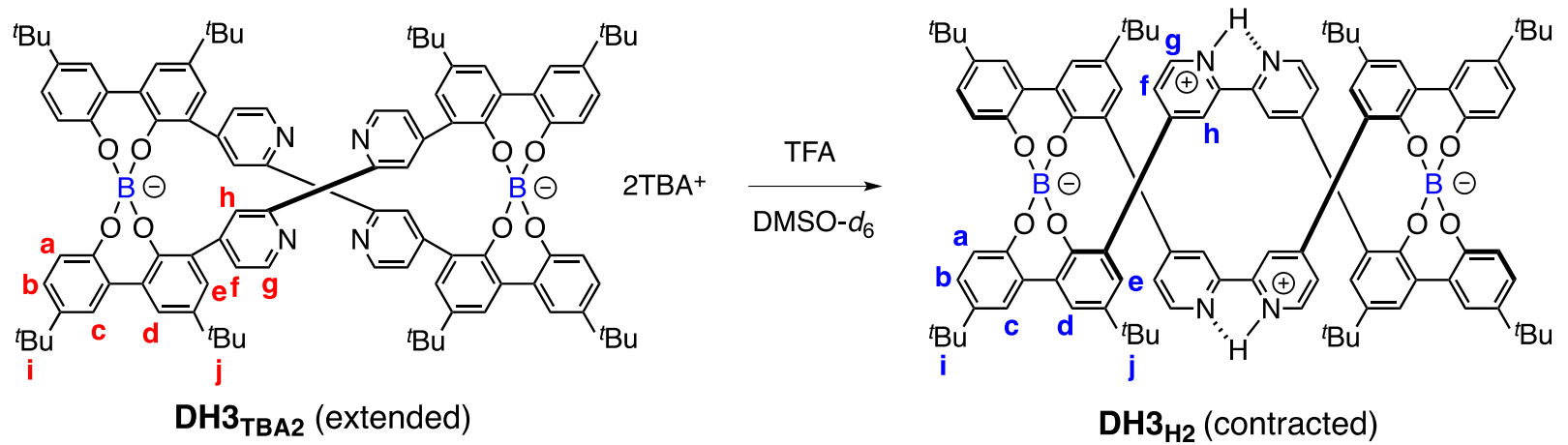

a)

(i) $\mathrm{DH}_{\text {TBA2 }}$

(ii) (i) + TFA (0.5 equiv.)

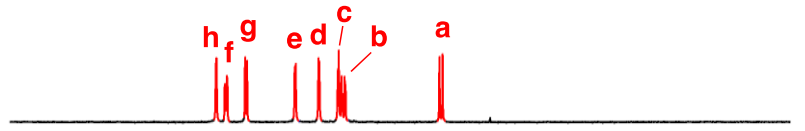

(iii) (i) + TFA (1.0 equiv.)

(iv) (i) + TFA (1.5 equiv.)

-

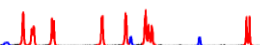

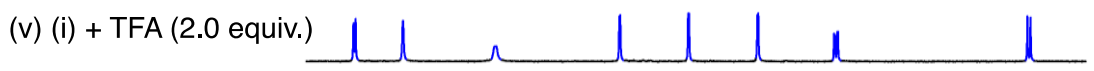

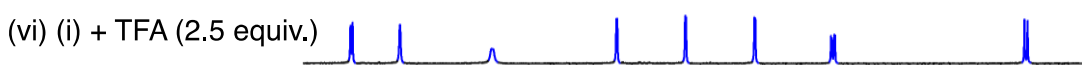

(vii) (i) + TFA (3.0 equiv.)
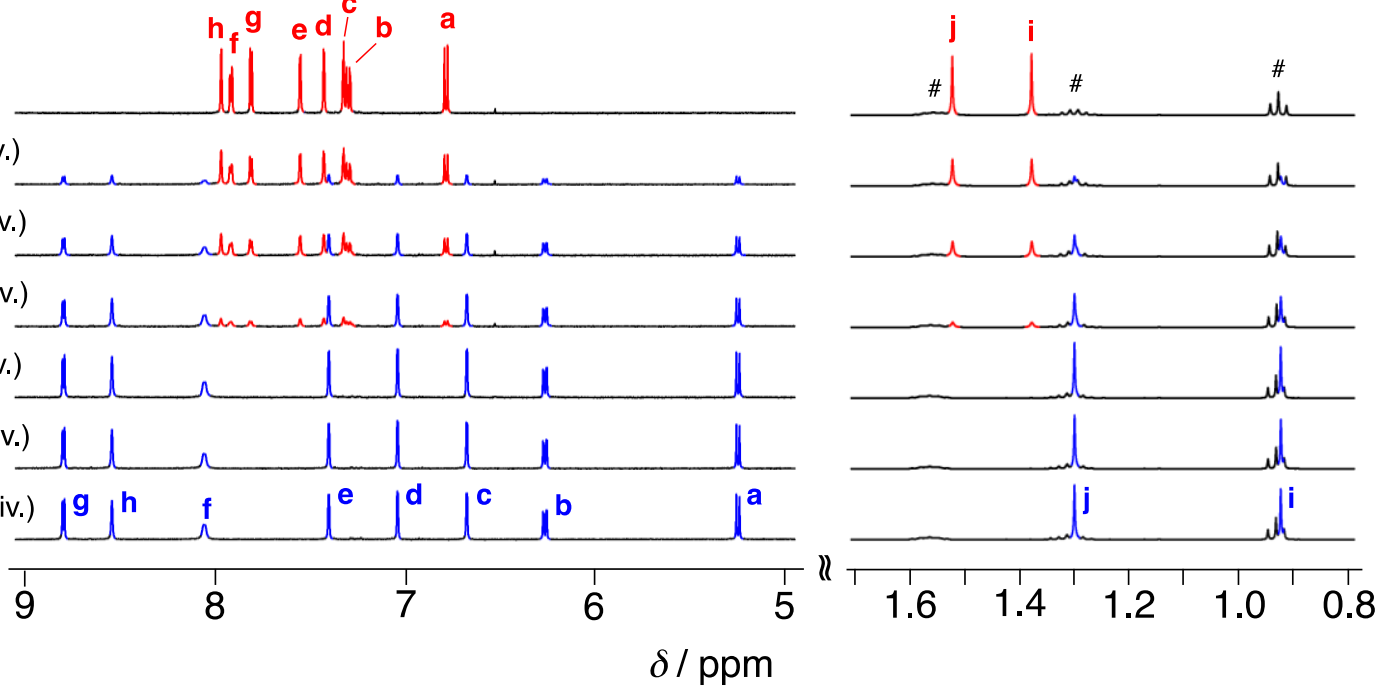

b)

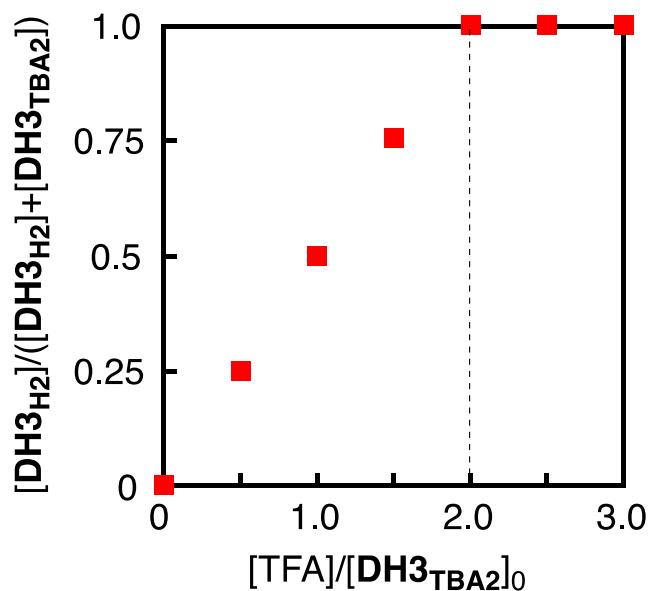

Figure S37. (a) Partial ${ }^{1} \mathrm{H}$ NMR spectra (500 MHz, DMSO- $d_{6}, 25^{\circ} \mathrm{C}, 0.5 \mathrm{mM}$ ) of DH3 TBA2 $_{\text {in }}$ in the presence of TFA (0-3 equiv.). \# denotes the protons from TBA ${ }^{+}$. (b) Plots of $\mathbf{D H}_{3} \mathbf{H}_{2}$ content as a function of $[\mathrm{TFA}] /\left[\mathrm{DH}_{\mathrm{TBA}}\right]_{0}$. 


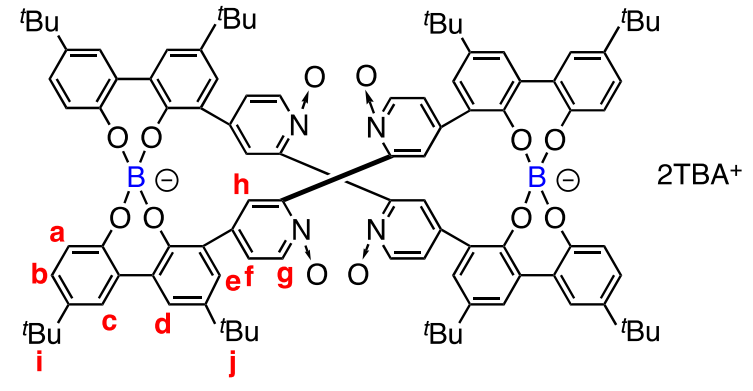

DH4 $_{\text {TBA2 }}$ (extended)

a)

(i) $\mathrm{DH}_{\mathrm{TBA}}$

(ii) (i) + TFA ( 0.5 equiv)

(iii) (i) + TFA (1.0 equiv)

(iv) (i) + TFA (1.5 equiv)

(v) (i) + TFA (2.0 equiv)

(vi) (i) + TFA (2.5 equiv)

(vii) (i) + TFA (3.0 equiv)

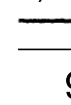

b)

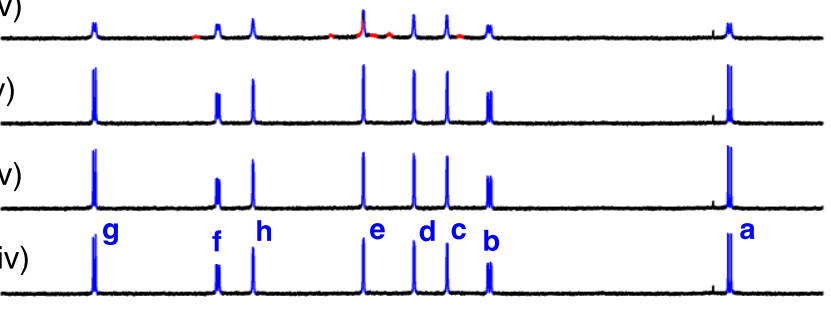

9

8

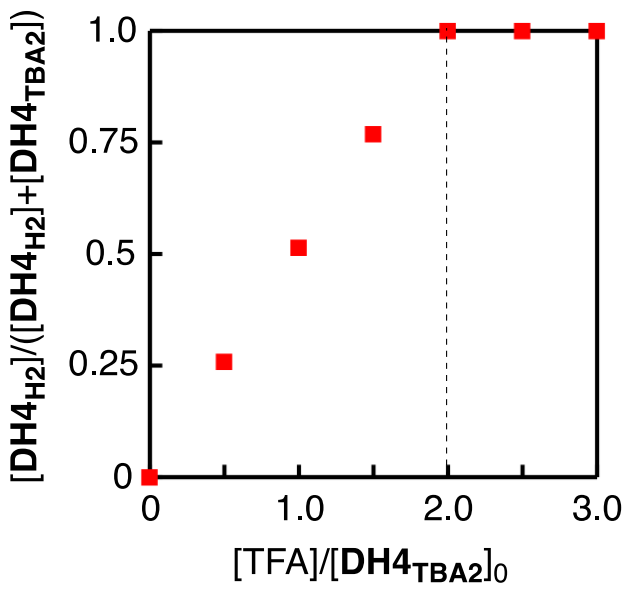

Figure S38. (a) Partial ${ }^{1} \mathrm{H}$ NMR spectra $\left(500 \mathrm{MHz}, \mathrm{CD}_{3} \mathrm{CN}, 25{ }^{\circ} \mathrm{C}, 0.5 \mathrm{mM}\right)$ of DH4TBA2 in the presence of TFA (0-3 equiv.). \# denotes the protons from TBA ${ }^{+}$. (b) Plots of $\mathbf{D H} 4 \mathbf{H}_{2}$ content as a function of $[\mathrm{TFA}] /[\mathbf{D H 4} \mathbf{T B A 2}]_{0}$.
$\mathrm{DH}_{\mathrm{H} 2}$ (contracted)
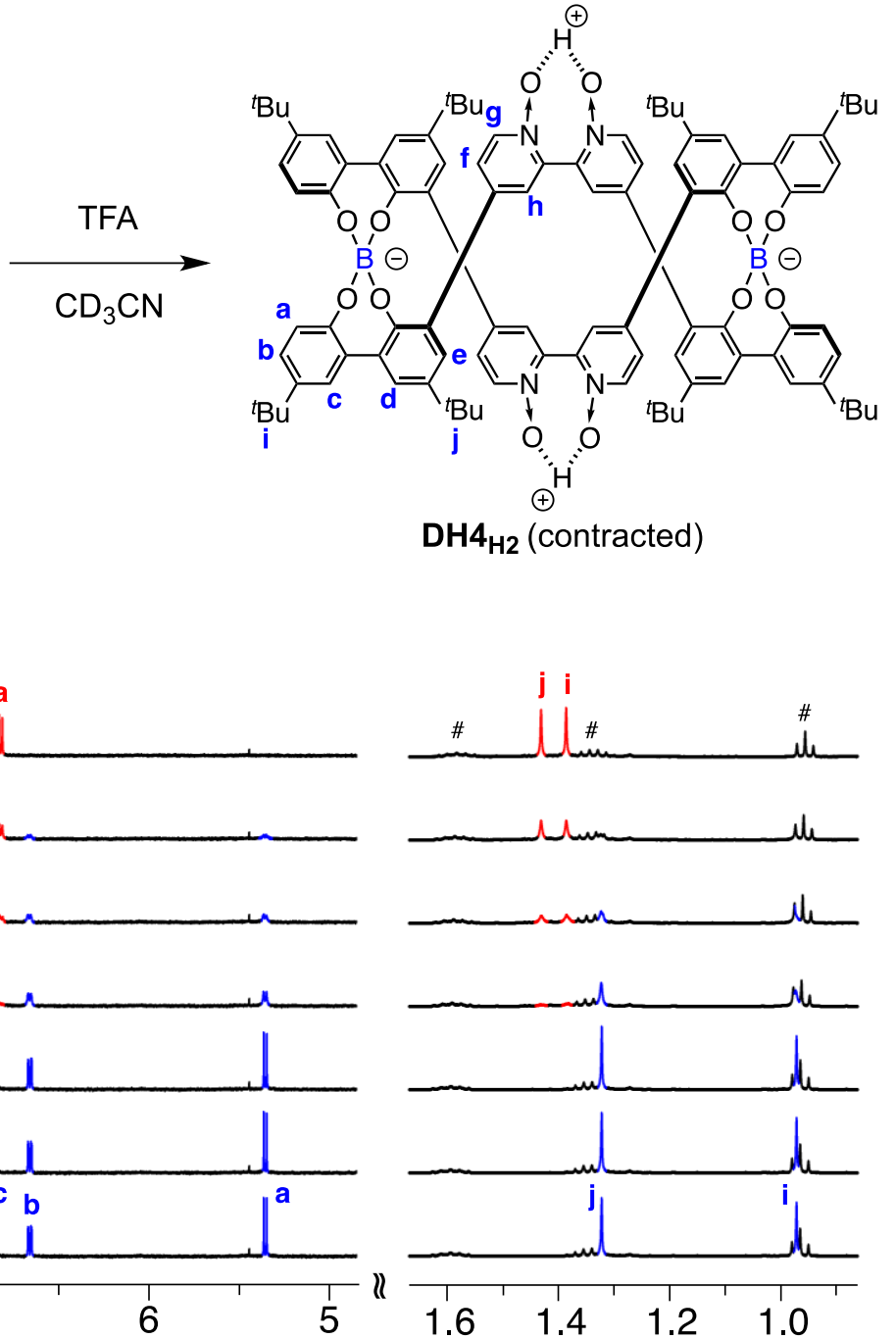

$\delta / \mathrm{ppm}$

$$
g, c, e, h
$$
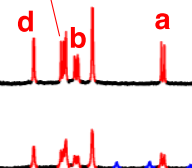

7

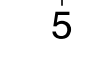



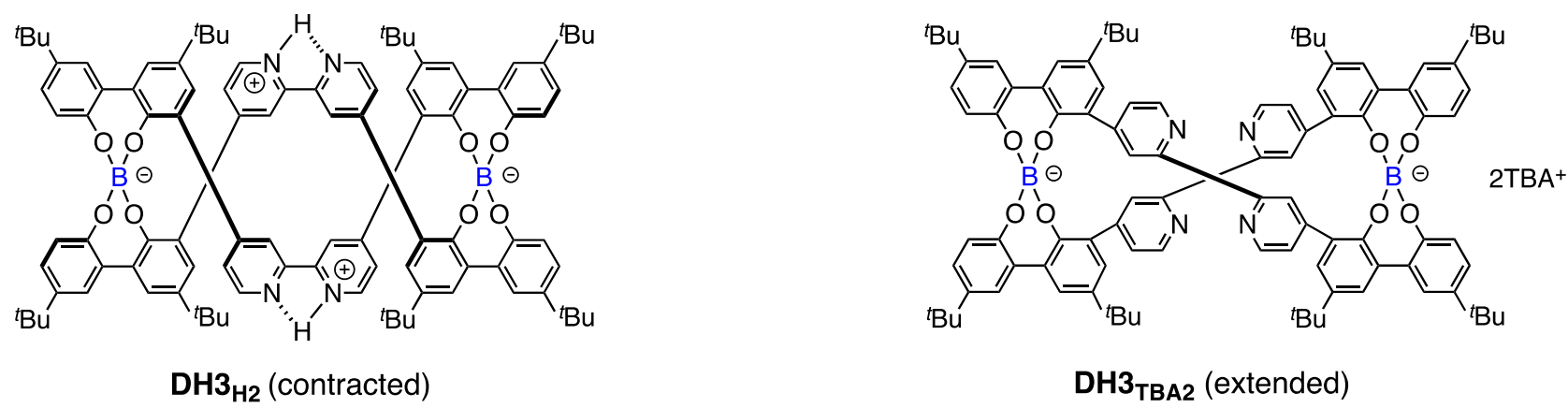

DH3
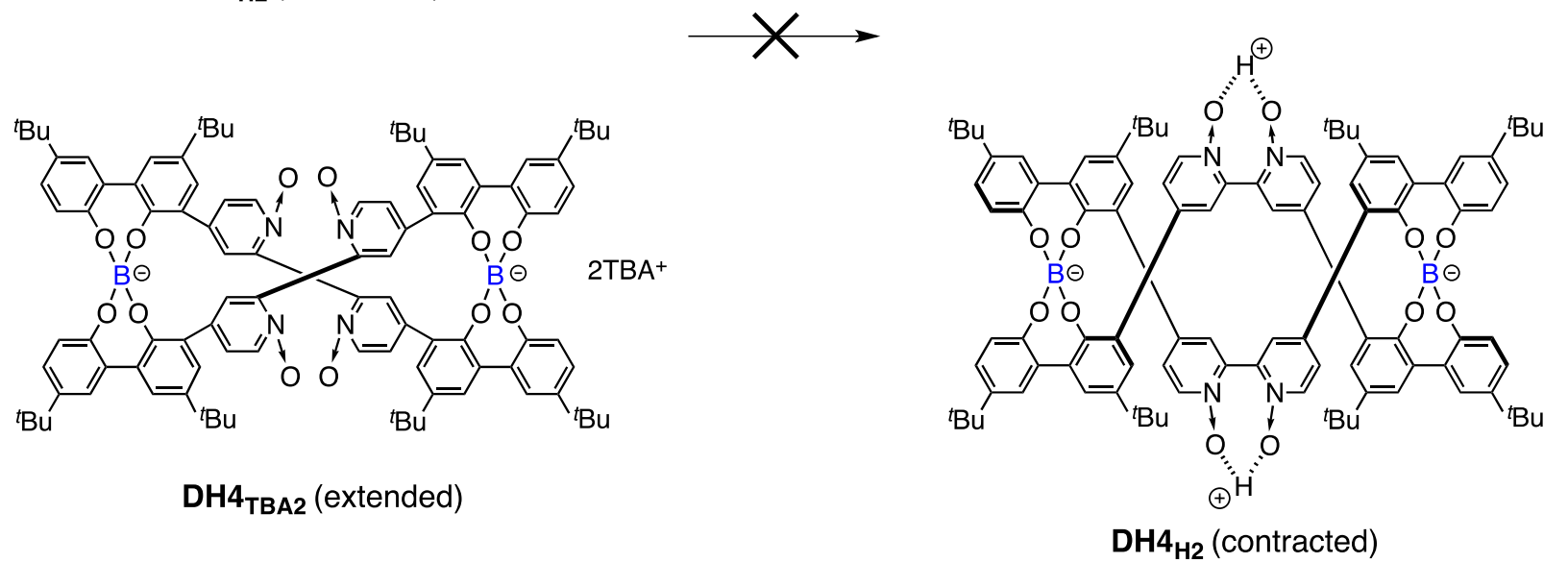

$\mathrm{DH}_{\mathrm{H} 2}$ (contracted)

(a) $\left[\mathrm{DH}_{\mathrm{H} 2}\right]$

DH4
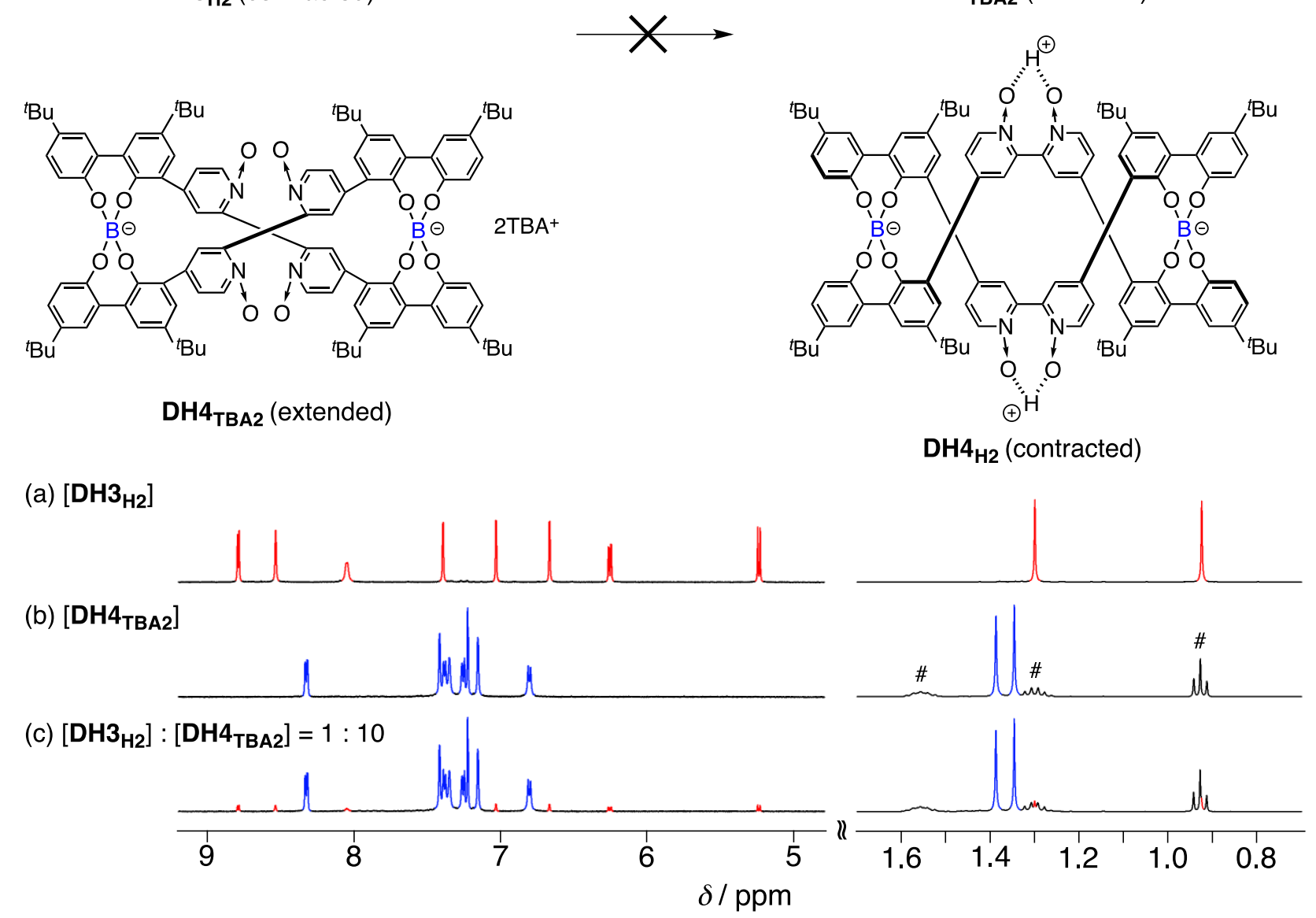

Figure S39. ${ }^{1} \mathrm{H}$ NMR spectra $\left(500 \mathrm{MHz}, \mathrm{DMSO}_{-} d_{6}, \mathrm{rt}\right)$ of DH3 $\mathbf{H}_{\mathbf{2}}$ (a), DH4 Tra2 (b), and a 1:10 mixture of $\mathrm{DH}_{3} \mathrm{H}_{2}$ and DH4 TBa2 (c). \# denotes the protons from $\mathrm{TBA}^{+}$. 
<smiles>CC(C)(C)c1ccc(O)c(-c2ccnc(-c3ccnc(-c4cc(C(C)(C)C)cc(-c5cc(C(C)(C)C)cc(-c6cc(C(C)(C)C)ccc6O)c5O)c4O)c3)c2)c1</smiles>

a)

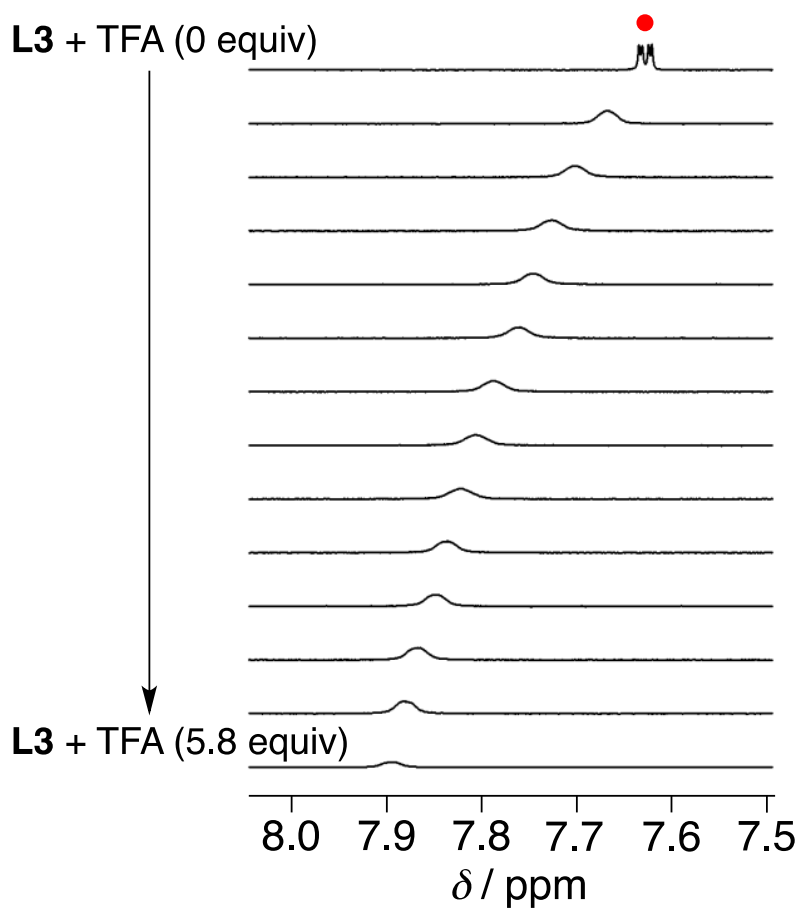

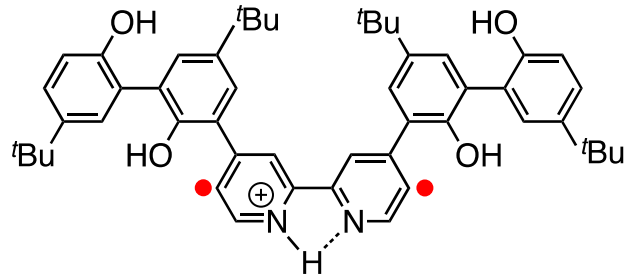

L3-TFA

b)

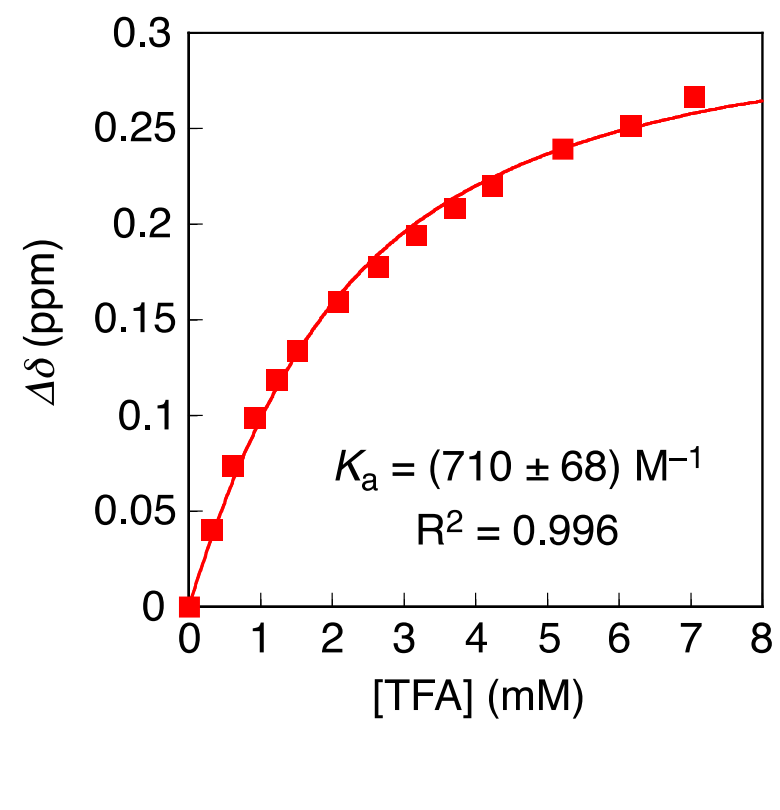

Figure S40. (a) Partial ${ }^{1} \mathrm{H}$ NMR spectra $\left(500 \mathrm{MHz}\right.$, DMSO- $\left.d_{6}, 25^{\circ} \mathrm{C}, 1.2 \mathrm{mM}\right)$ of $\mathbf{L 3}$ in the presence of TFA (0-5.8 equiv). (b) Plots of the ArH chemical shifts (5,5'-positions of the bpy moiety of $\mathbf{L 3}$ ) versus the concentration of TFA in DMSO- $d_{6}$. The curve in the plots was obtained by the curve-fitting method (1:1 binding model), giving the association constant $\left(K_{\mathrm{a}}\right)$ for L3-TFA to be $710 \pm 68 \mathrm{M}^{-1}$. 


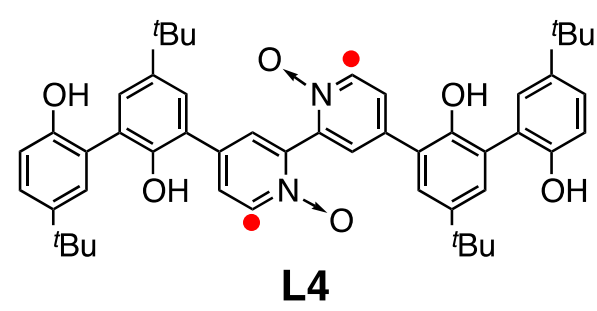

a)

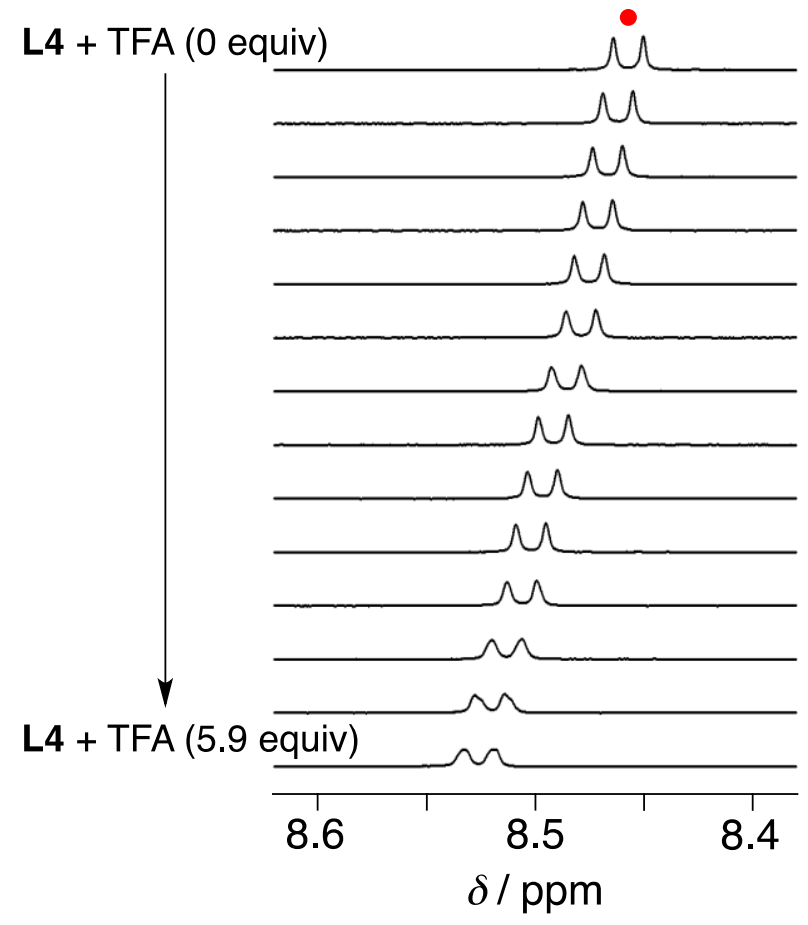

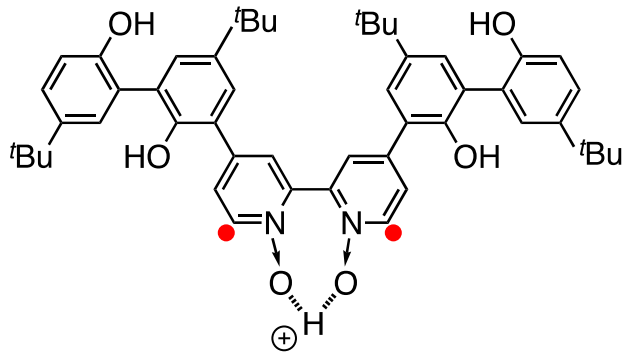

b)

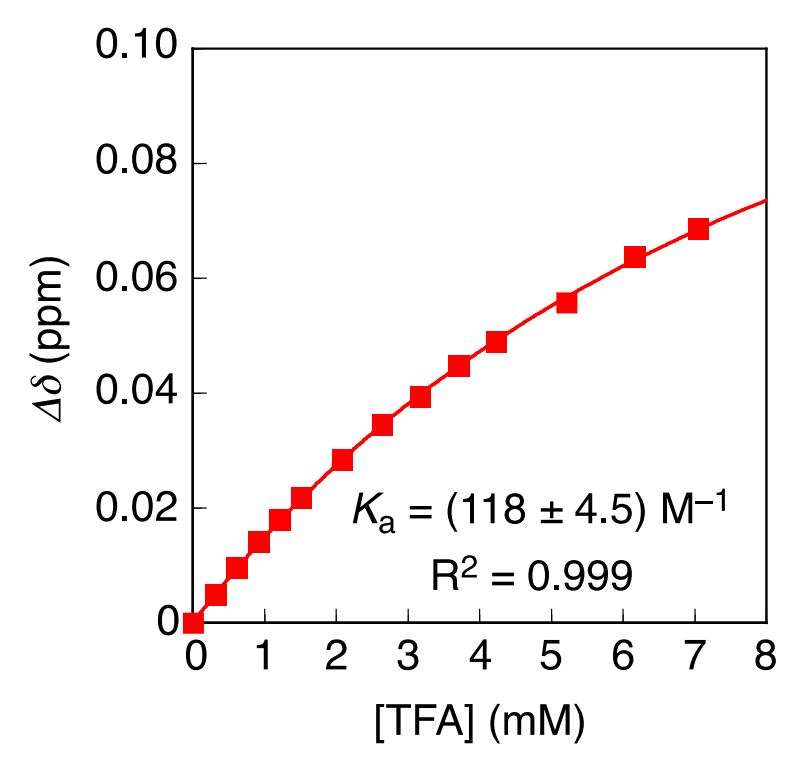

Figure S41. (a) Partial ${ }^{1} \mathrm{H}$ NMR spectra $\left(500 \mathrm{MHz}\right.$, DMSO- $\left.d_{6}, 25^{\circ} \mathrm{C}, 1.2 \mathrm{mM}\right)$ of $\mathbf{L} 4$ in the presence of TFA (0-5.9 equiv). (b) Plots of the ArH chemical shifts (6,6'-positions of the bpy $N, N^{\prime}$ dioxide moiety of L4) versus the concentration of TFA in DMSO- $d_{6}$. The curve in the plots was obtained by the curve-fitting method (1:1 binding model), giving the association constant $\left(K_{\mathrm{a}}\right)$ for L4-TFA to be $118 \pm 4.5 \mathrm{M}^{-1}$. 


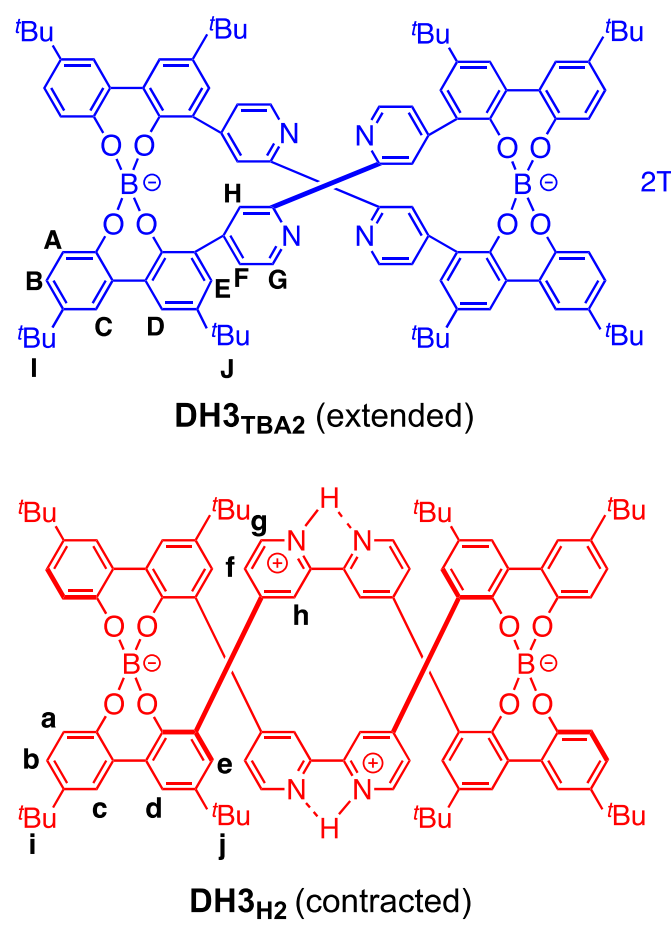

a)

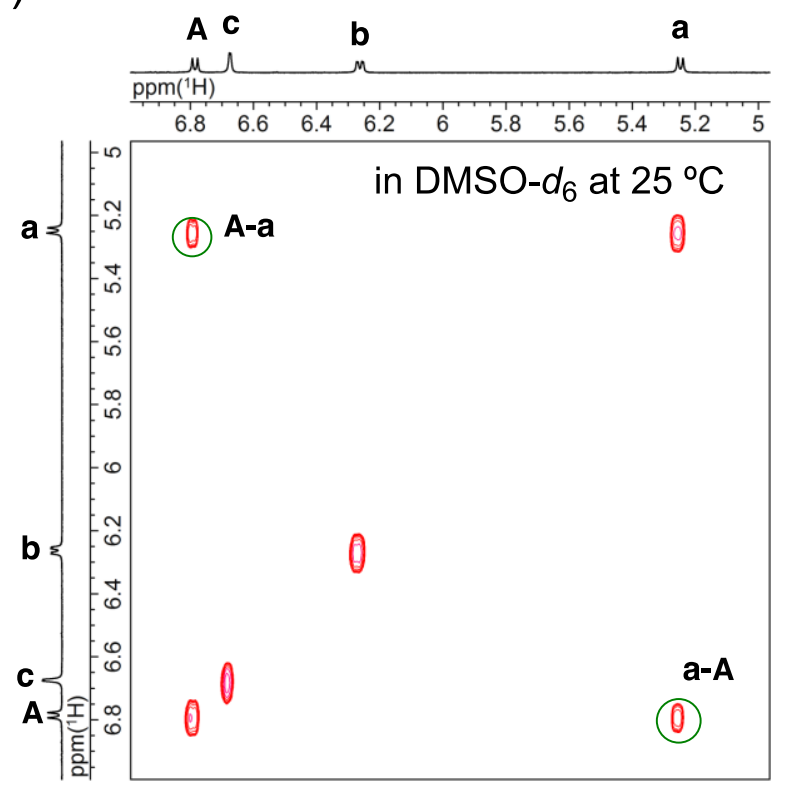

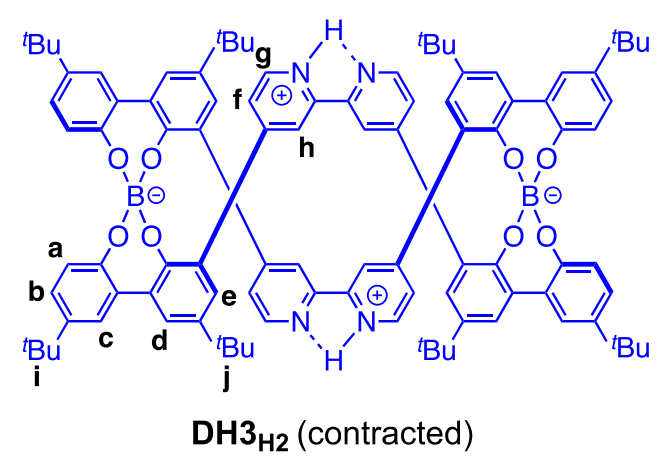

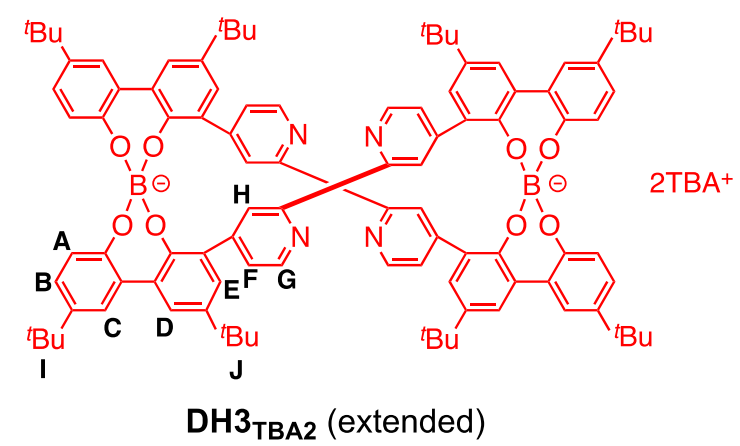

b)

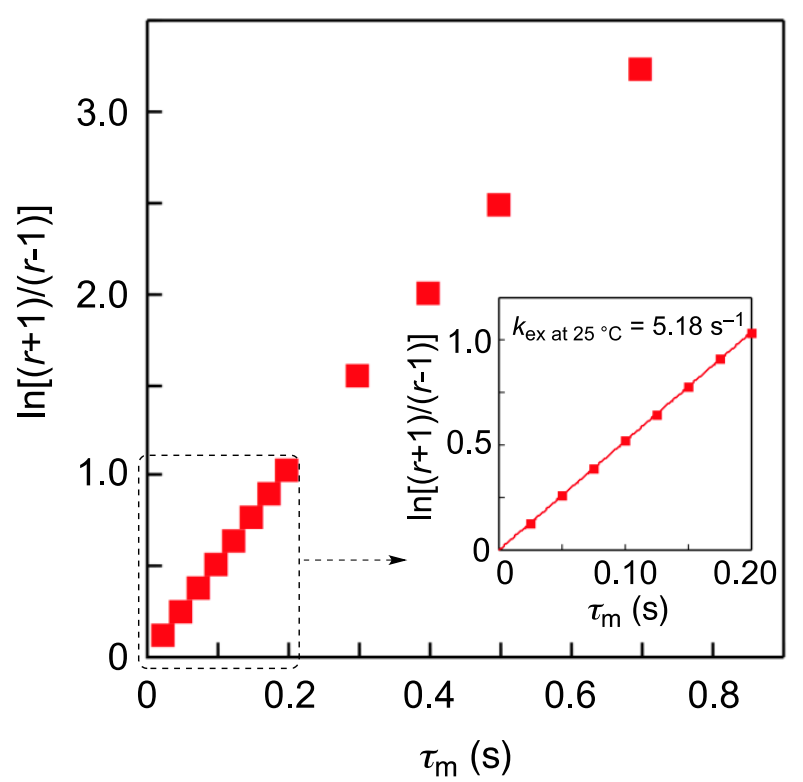

Figure S42. Determination of the apparent exchange rate constant, $k_{\mathrm{ex}}\left(k_{\mathrm{ex}}=k_{1}+k_{-1}\right)$, for interconversion between DH3 ${ }_{\text {TBA2 }}$ (extended) and $\mathbf{D H} 3_{\mathbf{H} 2}$ (contracted). (a) Partial 2D EXSY (NOESY) spectrum (500 MHz, DMSO- $d_{6}, 25^{\circ} \mathrm{C}, 2.0 \mathrm{mM}$, mixing time $\left.\left(\tau_{\mathrm{m}}\right)=0.2 \mathrm{~s}\right)$ of DH3 $\mathbf{T B A 2}$ in the presence of 1 equiv of TFA. (b) Plots of $\ln [(r+1) /(r-1)]$ as a function of $\tau_{\mathrm{m}}$ in the presence of 1 equiv of TFA in DMSO- $d_{6}$ at $25^{\circ} \mathrm{C}$. 


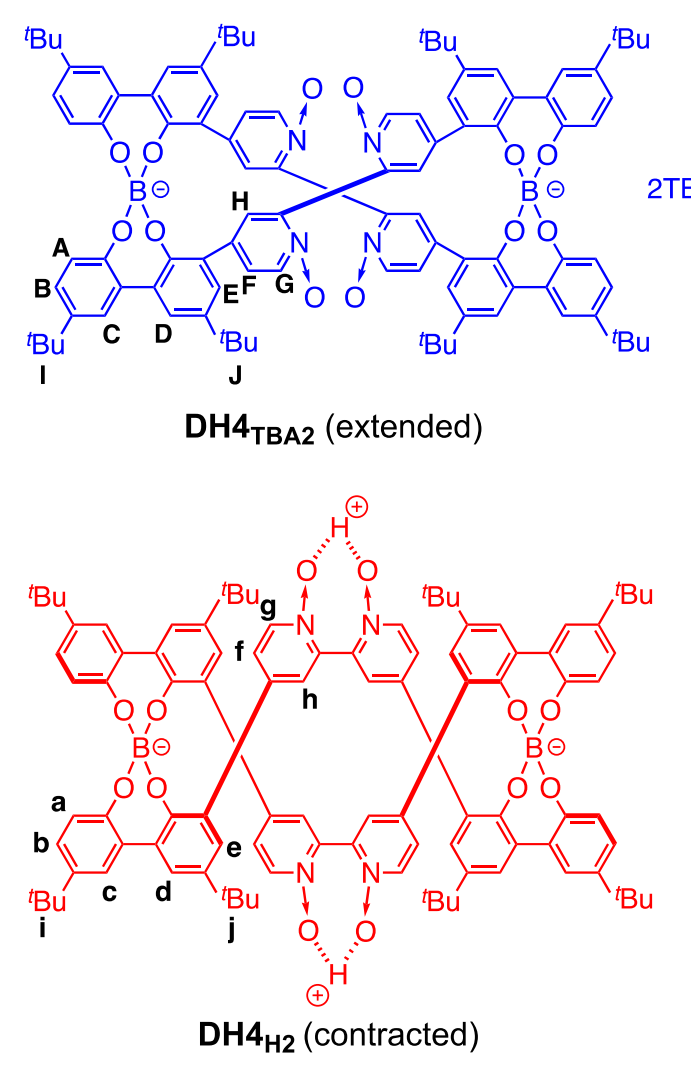

a)

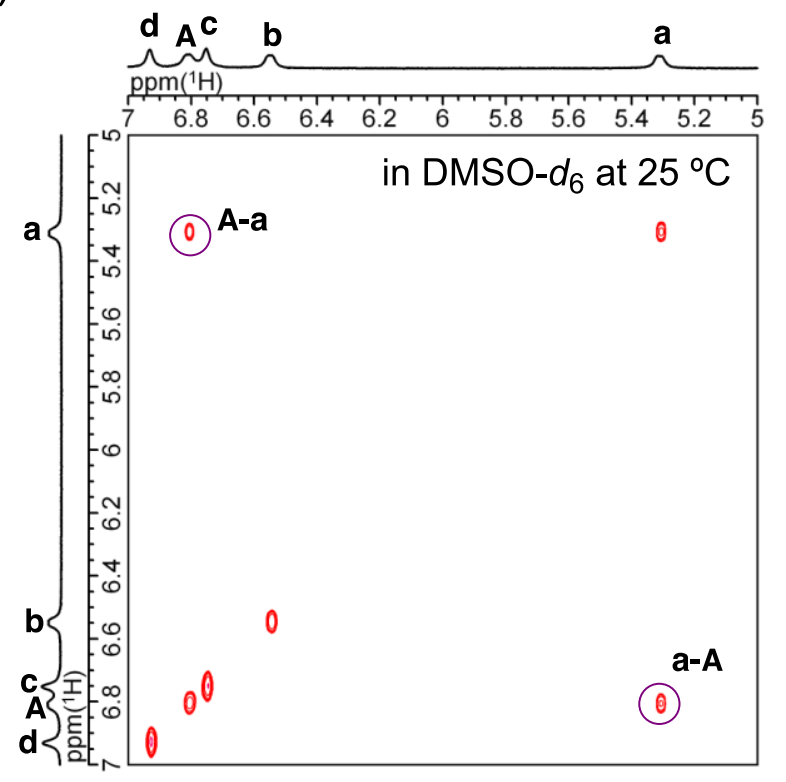

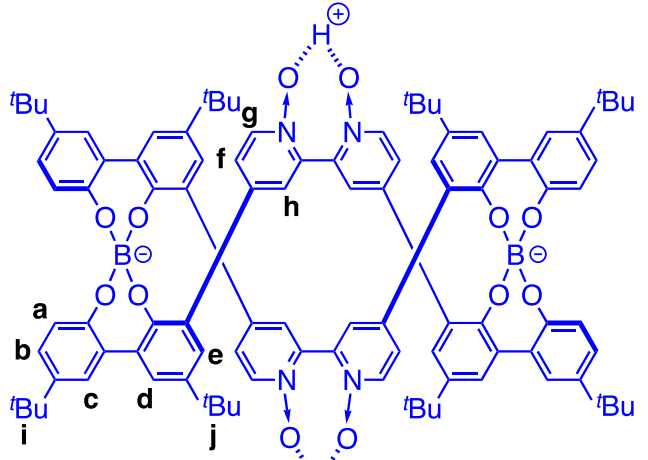
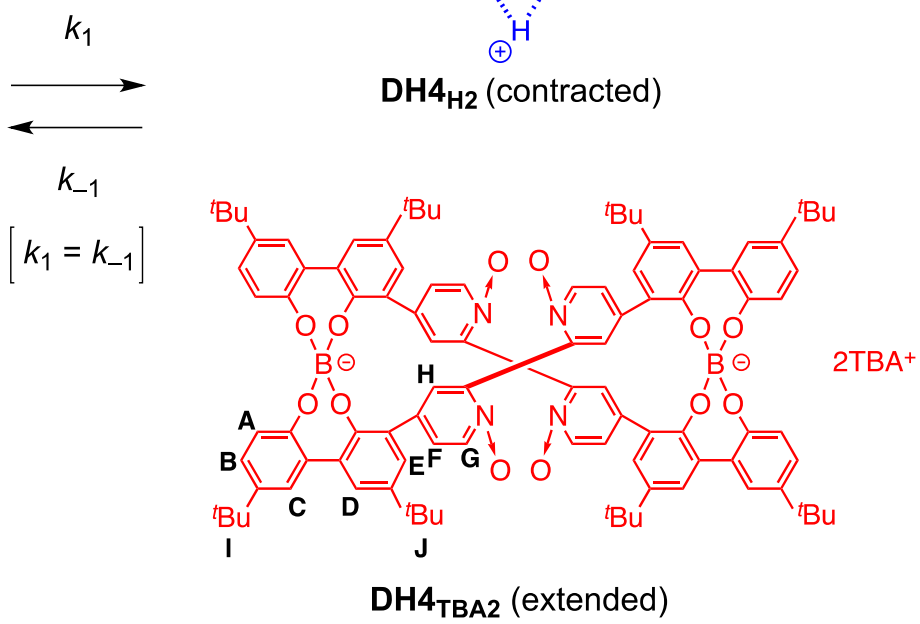

b)

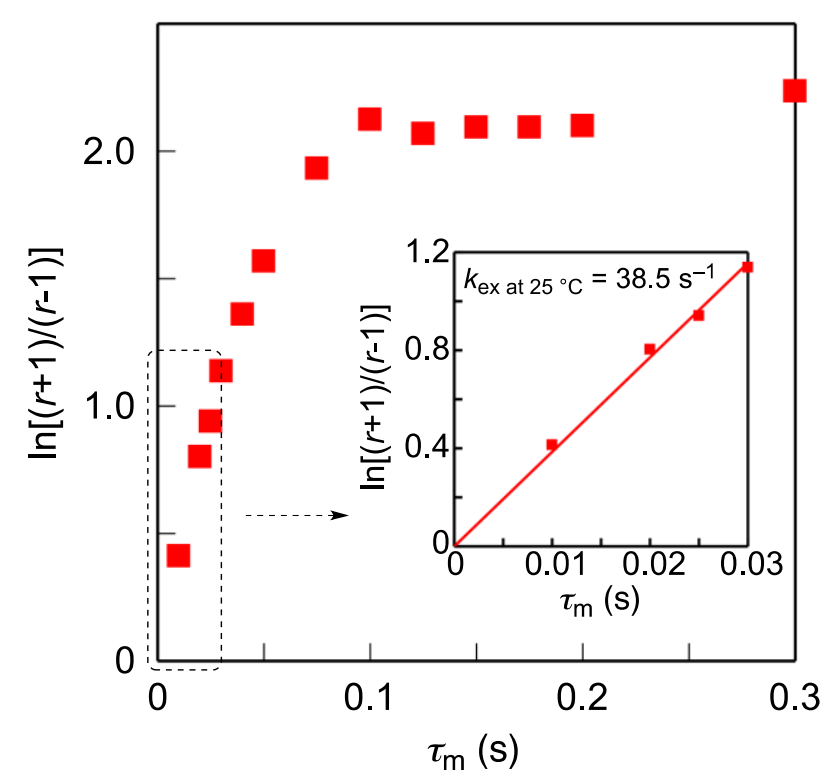

Figure S43. Determination of the apparent exchange rate constants, $k_{\mathrm{ex}}\left(k_{\mathrm{ex}}=k_{1}+k_{-1}\right)$, for interconversion between DH4 TBA2 (extended) and DH4 $\mathbf{H}_{2}$ (contracted). a) Partial 2D EXSY (NOESY) spectra (500 MHz, $2.0 \mathrm{mM}$ ) of DH4 $\mathbf{T B A}_{\mathbf{T} 2}$ in the presence of 1 equiv of TFA in DMSO- $d_{6}$ at $25^{\circ} \mathrm{C}\left(\tau_{\mathrm{m}}=0.2 \mathrm{~s}\right)$. b) Plots of $\ln [(r+1) /(r-1)]$ as a function of $\tau_{\mathrm{m}}$ for DH4 $\mathbf{T B A 2}$ in the presence of 1 equiv of TFA in DMSO- $d_{6}$ at $25^{\circ} \mathrm{C}$. 


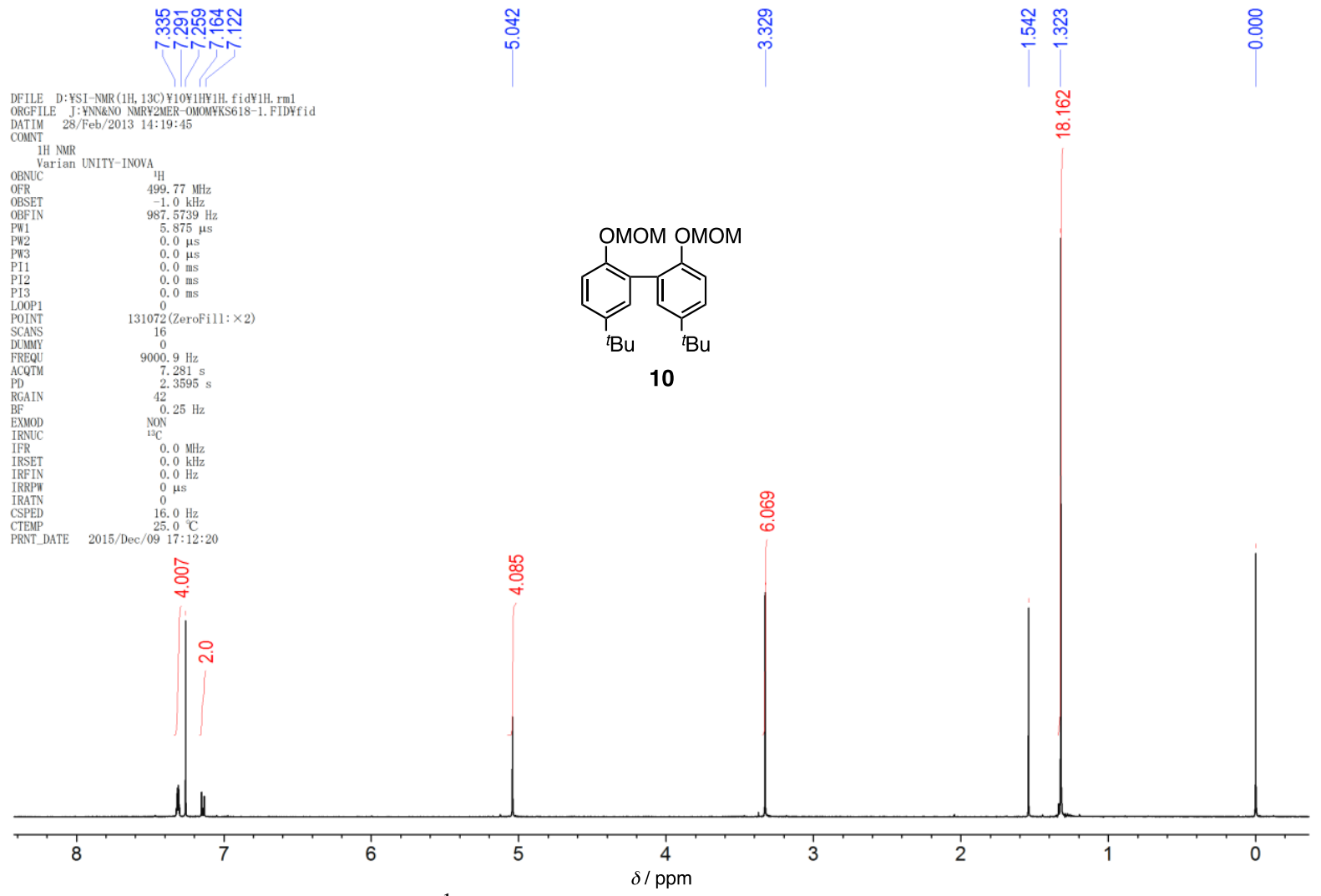

Figure S44. ${ }^{1} \mathrm{H}$ NMR spectrum of 10 in $\mathrm{CDCl}_{3}$ at $25^{\circ} \mathrm{C}$.
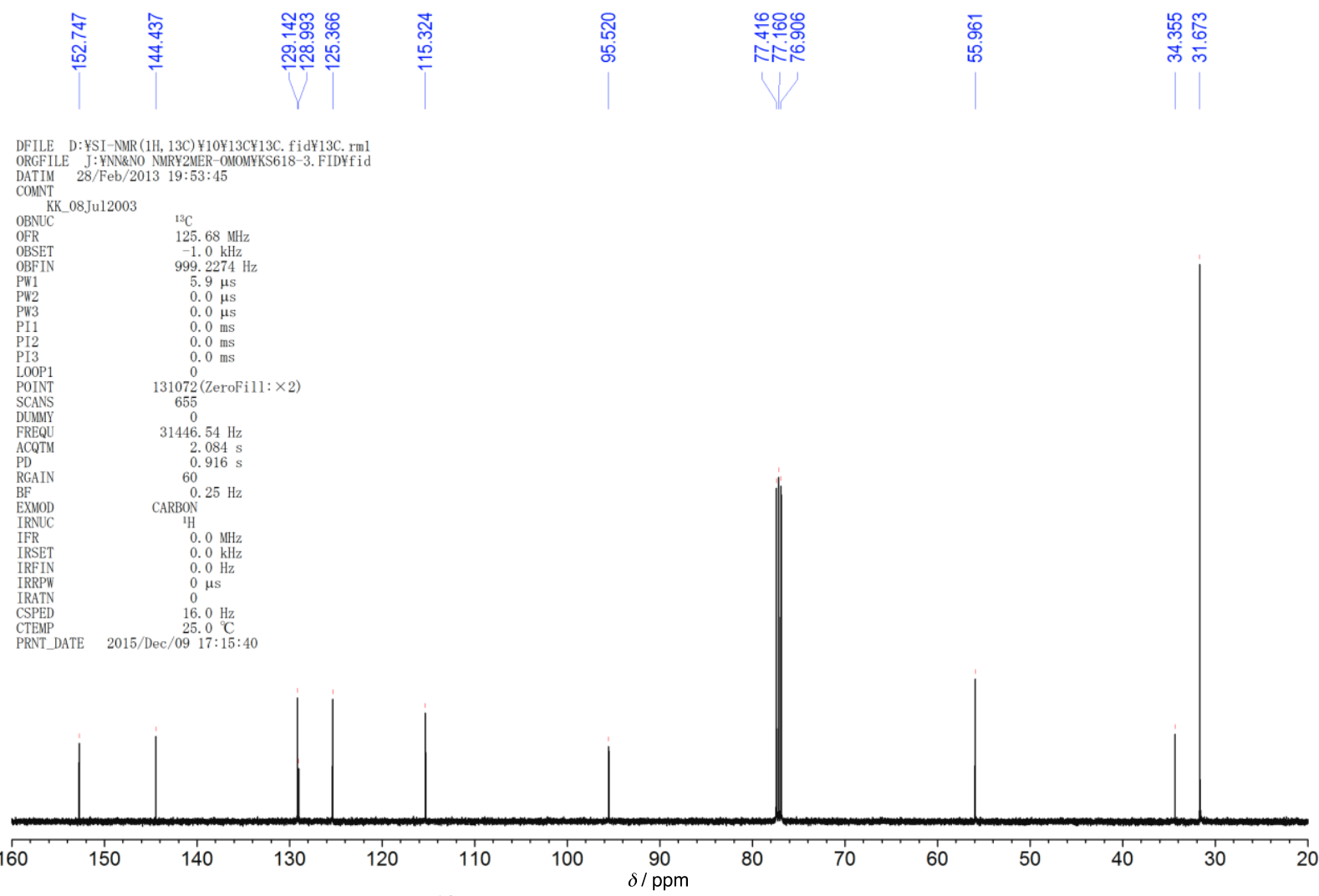

Figure S45. ${ }^{13} \mathrm{C}$ NMR spectrum of 10 in $\mathrm{CDCl}_{3}$ at $25{ }^{\circ} \mathrm{C}$. 


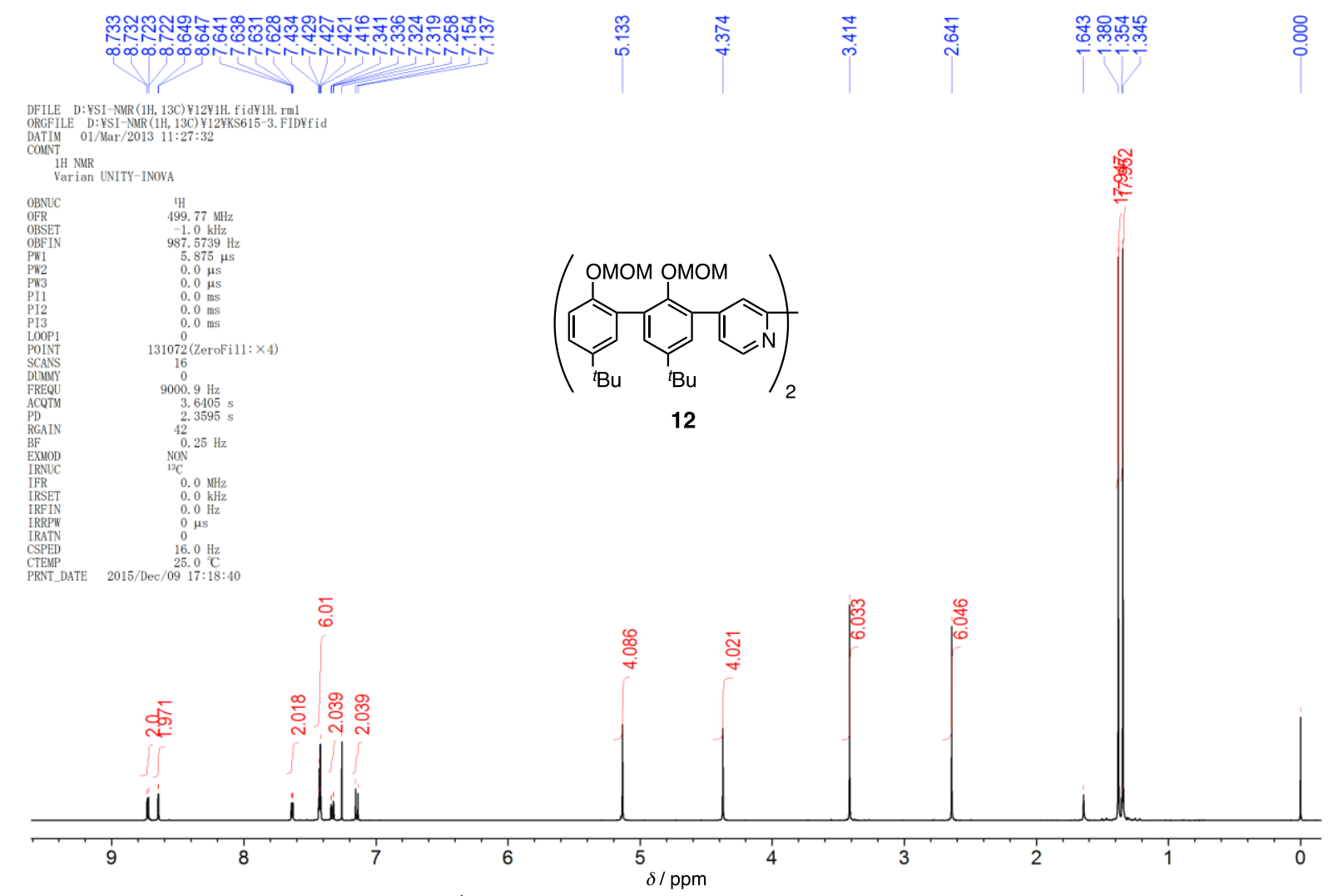

Figure S46. ${ }^{1} \mathrm{H}$ NMR spectrum of 12 in $\mathrm{CDCl}_{3}$ at $25{ }^{\circ} \mathrm{C}$.
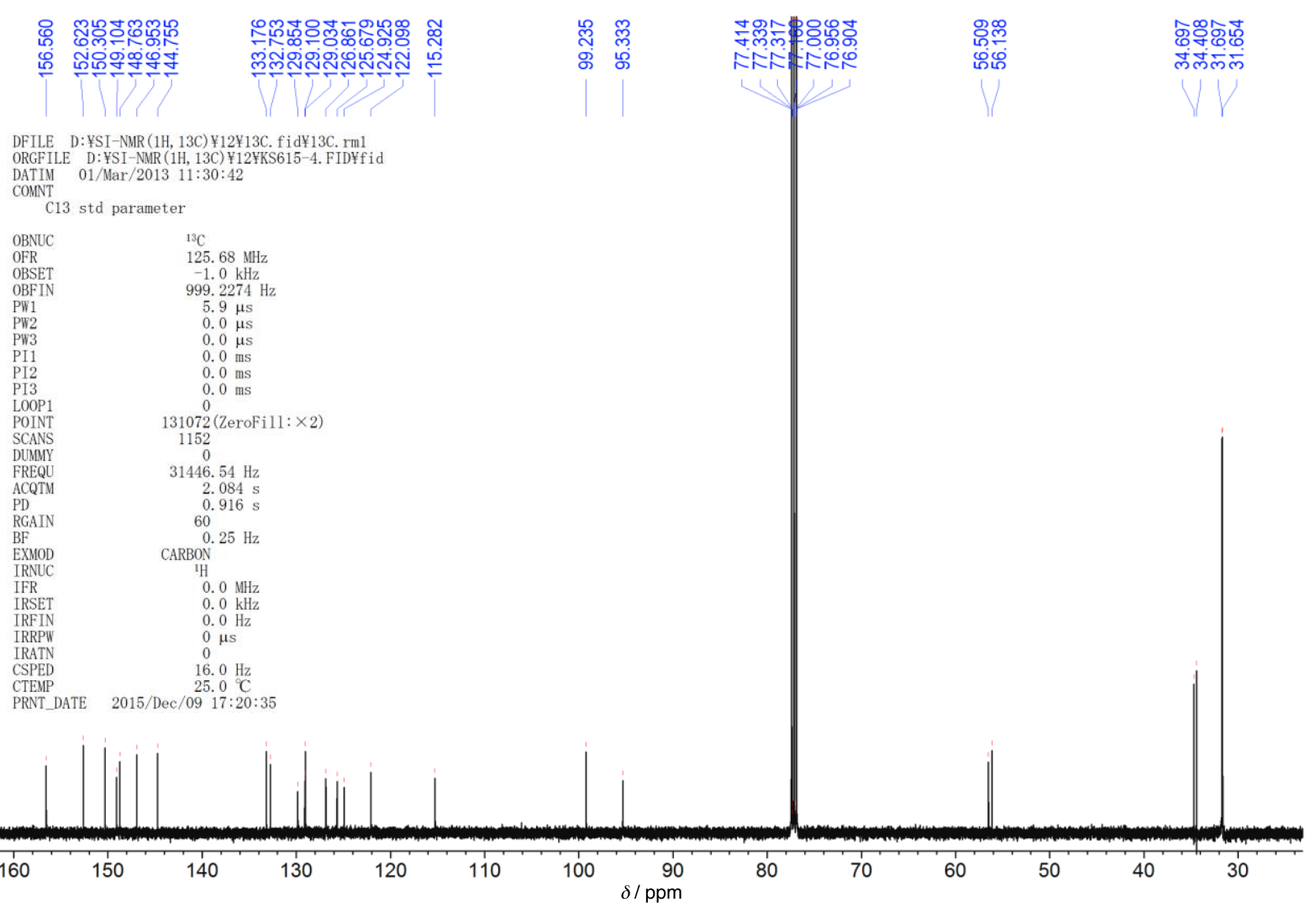

Figure S47. ${ }^{13} \mathrm{C}$ NMR spectrum of 12 in $\mathrm{CDCl}_{3}$ at $25{ }^{\circ} \mathrm{C}$. 


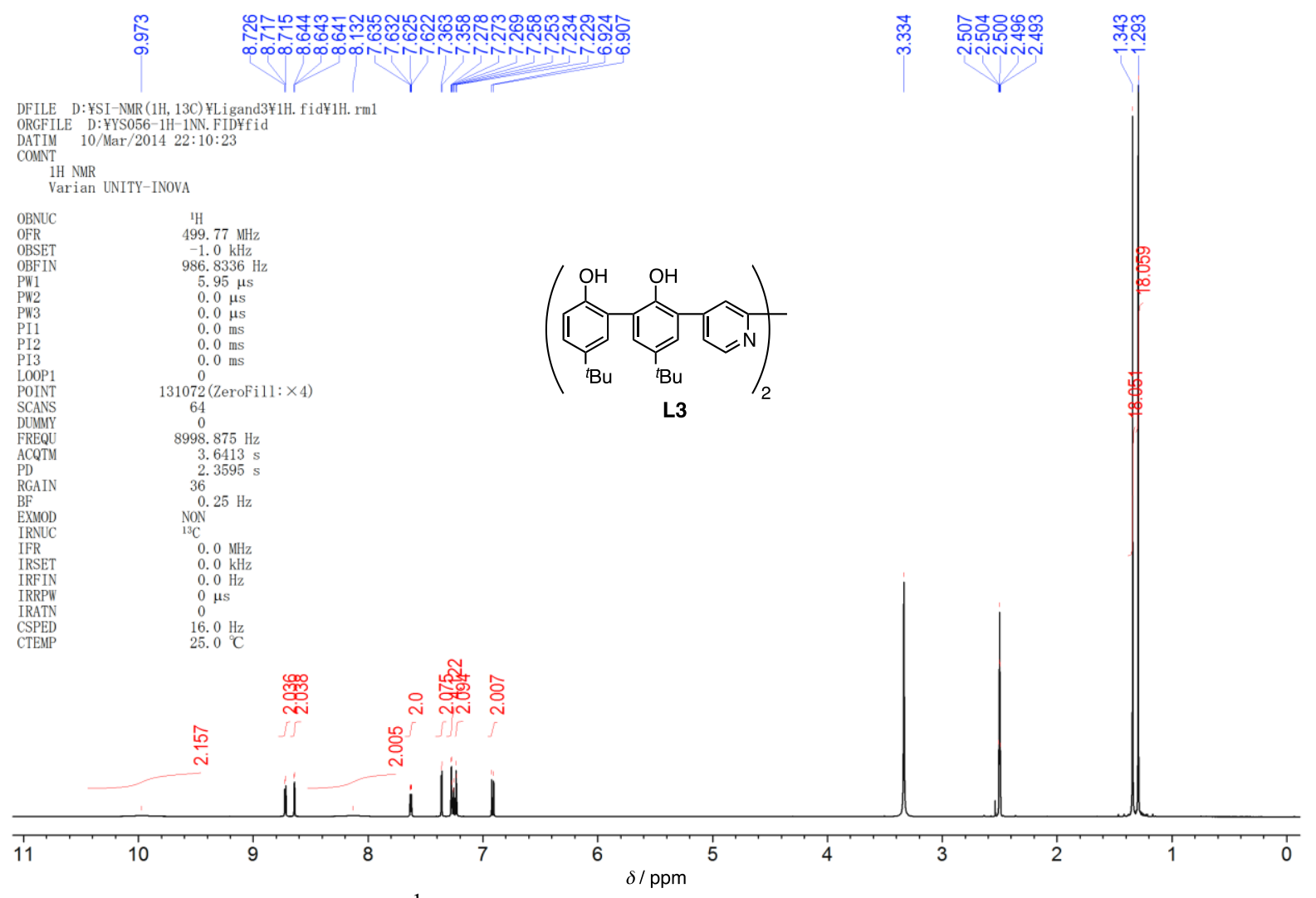

Figure S48. ${ }^{1} \mathrm{H}$ NMR spectrum of $\mathbf{L 3}$ in DMSO- $d_{6}$ at $25^{\circ} \mathrm{C}$.

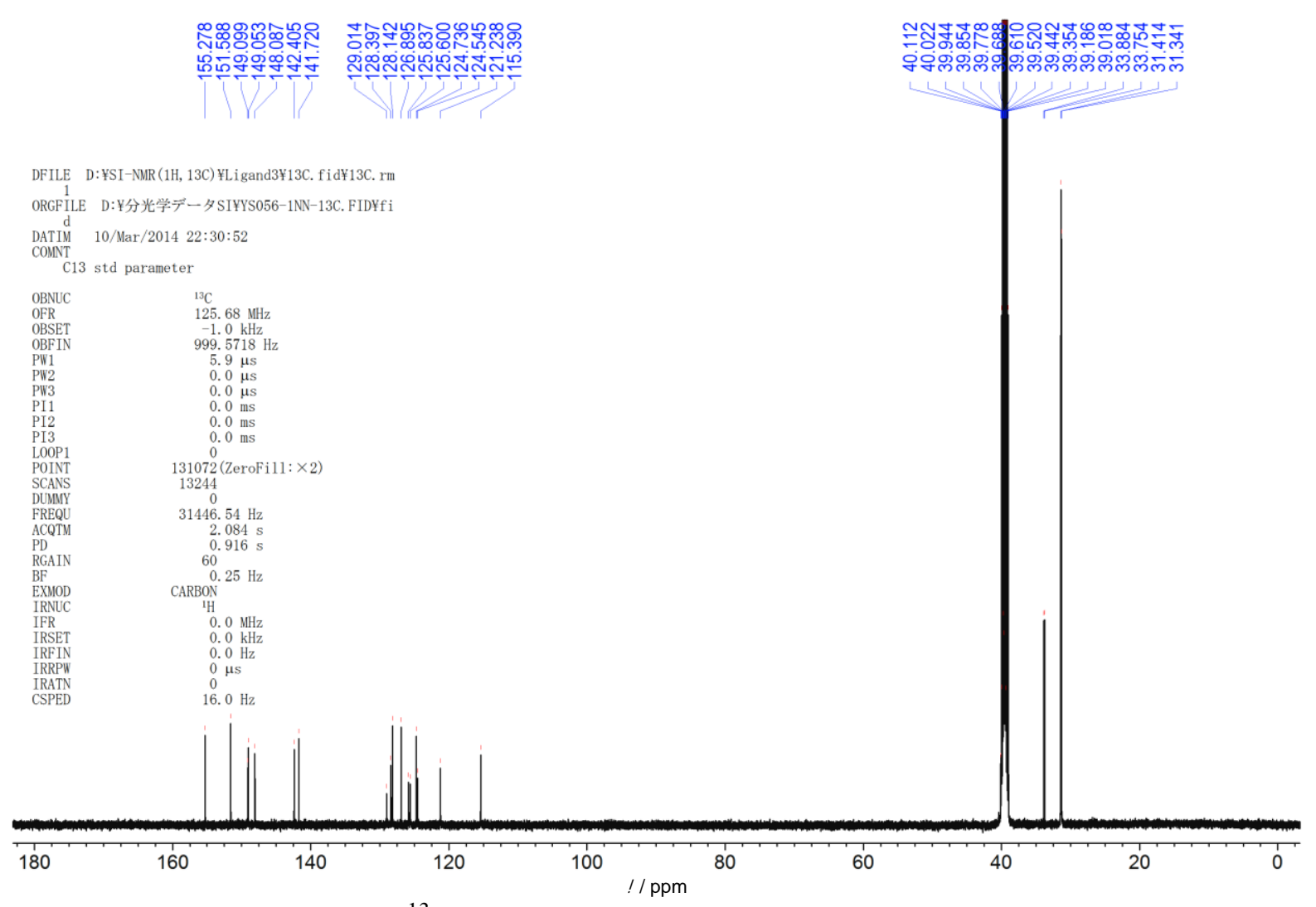

Figure S49. ${ }^{13} \mathrm{C}$ NMR spectrum of $\mathbf{L 3}$ in DMSO- $d_{6}$ at $25{ }^{\circ} \mathrm{C}$. 


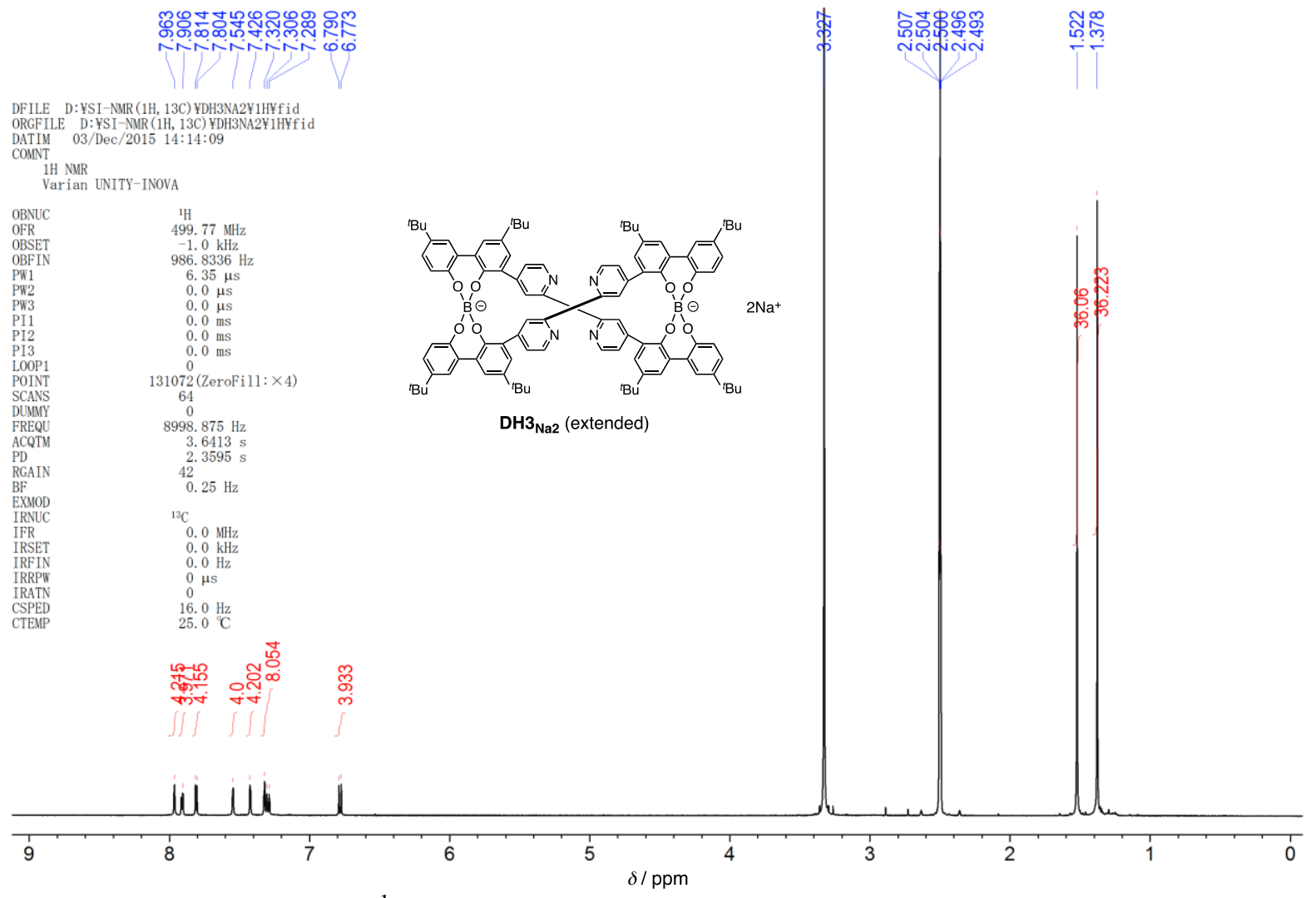

Figure S50. ${ }^{1} \mathrm{H}$ NMR spectrum of DH3 ${ }_{\mathrm{Na} 2}$ in DMSO- $d_{6}$ at $25{ }^{\circ} \mathrm{C}$.

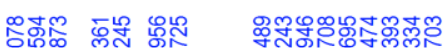

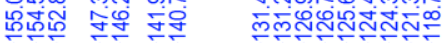

DFILE D: $¥ S I-N M R(1 H, 13 C) ¥ D H 3 N A 2 ¥ 13 C ¥ 20 ¥ P D A T A ¥ 1 ¥$

II ORGFILE D: : $S I-N M R(1 H, 13 C) ¥ D H 3 N A 2 ¥ 13 C ¥ 20 ¥ P D A T A ¥$

1¥11
DAIIMT
CONNT

${ }^{13} \mathrm{C}$

$0.0 \mathrm{kHz}$

$10001.26 \mathrm{~Hz}$

10. 0 Hs

20.045

$2.0 \mathrm{~ms}$

$0.0 \mathrm{~ms}$
$0.0 \mathrm{~ms}$

0

32768

10000
4
$29761.9 \mathrm{~Hz}$

$9761.9 \mathrm{~Hz}$

$2.0 \mathrm{~s}$
195

$0.25 \mathrm{~Hz}$

GPG30

${ }_{0.0} 0 \mathrm{MHz}$

$0.0 \mathrm{MHz}$
$0.0 \mathrm{kHz}$

${ }_{0}^{0} \mu$

20. $0 \mathrm{~Hz}$

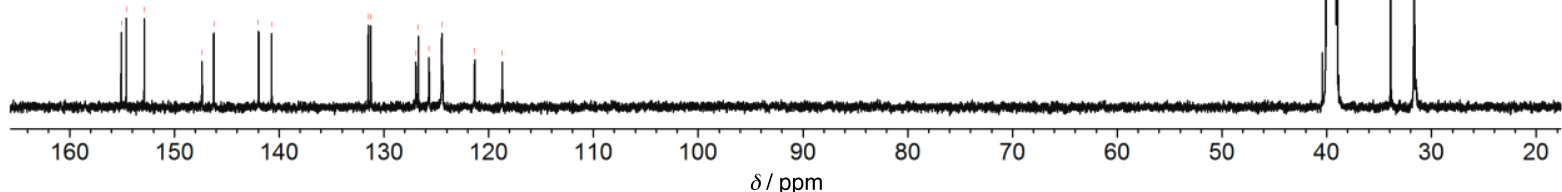

Figure S51. ${ }^{13} \mathrm{C}$ NMR spectrum of $\mathrm{DH3}_{\mathrm{Na} 2}$ in DMSO- $d_{6}$ at $25{ }^{\circ} \mathrm{C}$. 


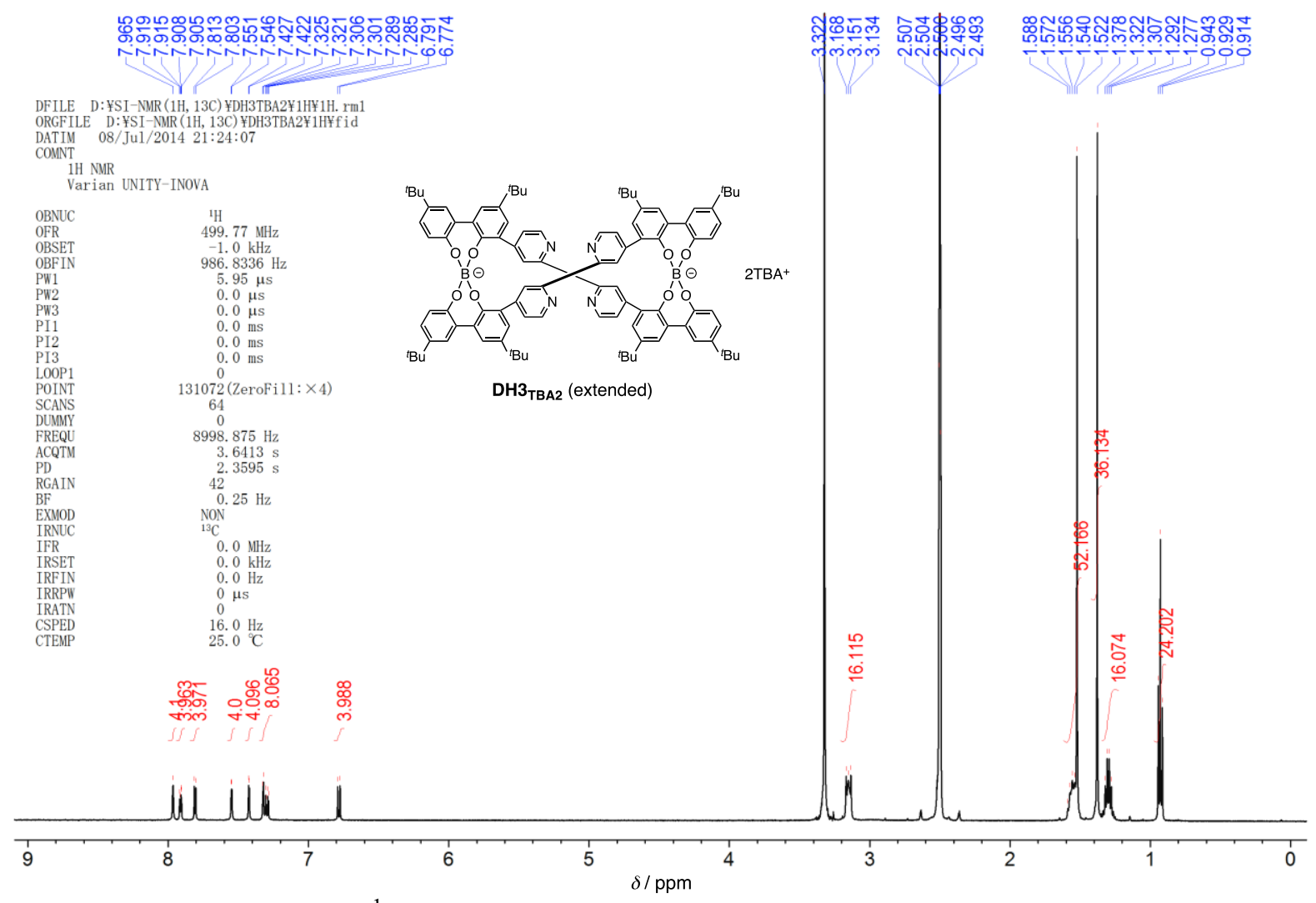

Figure S52. ${ }^{1} \mathrm{H}$ NMR spectrum of DH3 $\mathbf{T B A 2}$ in DMSO- $d_{6}$ at $25^{\circ} \mathrm{C}$.

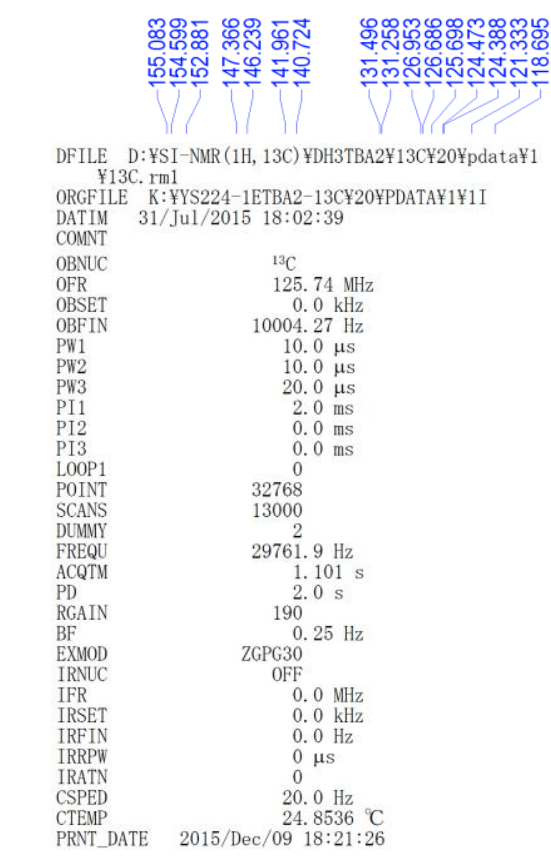

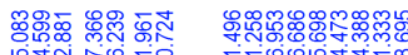

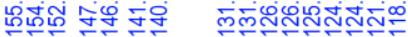

DFILE D: ¥SI-NMR (1H, 13C) ¥DH3TBA2 $¥ 13$ C¥20¥pdata¥1

ORGFILE K: K: YYS224-1ETBA2-13C¥20¥PDATA¥1¥11

DATIM $31 / \mathrm{Jul} / 2015$ 18:02:3

P12

FREQU

IFR

PRNT DATE $2015 / \mathrm{Dec} / 09$ 18:21:2

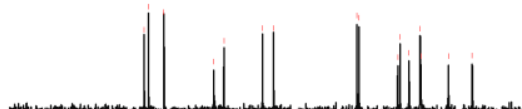

$160+140$

120

100

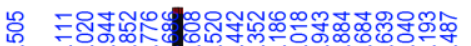

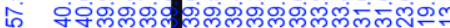

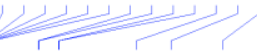

Figure S53. ${ }^{13} \mathrm{C}$ NMR spectrum of DH3 TBA2 $_{\text {in DMSO- }} d_{6}$ at $25{ }^{\circ} \mathrm{C}$. 


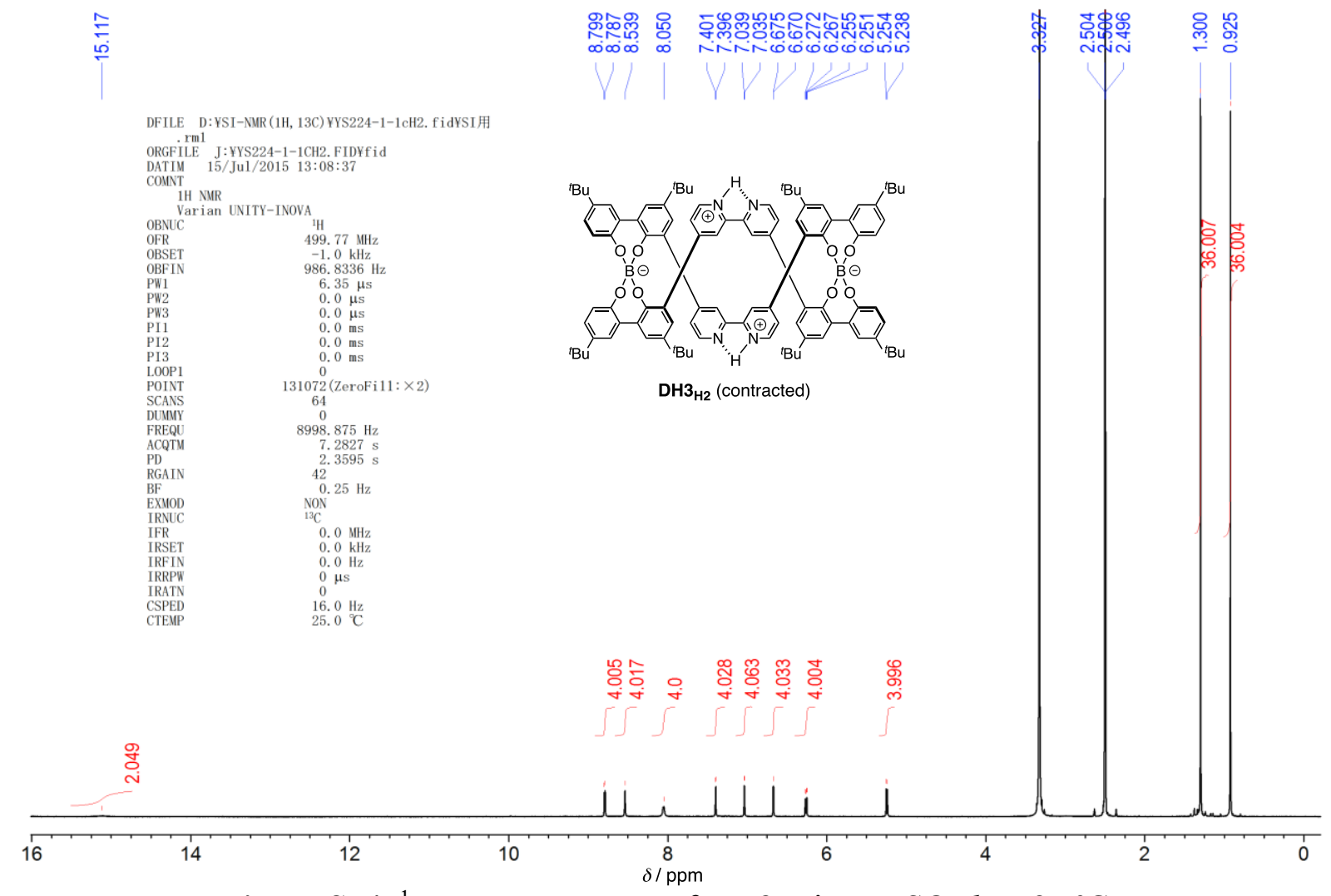

Figure S54. ${ }^{1} \mathrm{H}$ NMR spectrum of $\mathbf{D H} 3_{\mathbf{H}}$ in $\mathrm{DMSO}-d_{6}$ at $25^{\circ} \mathrm{C}$.

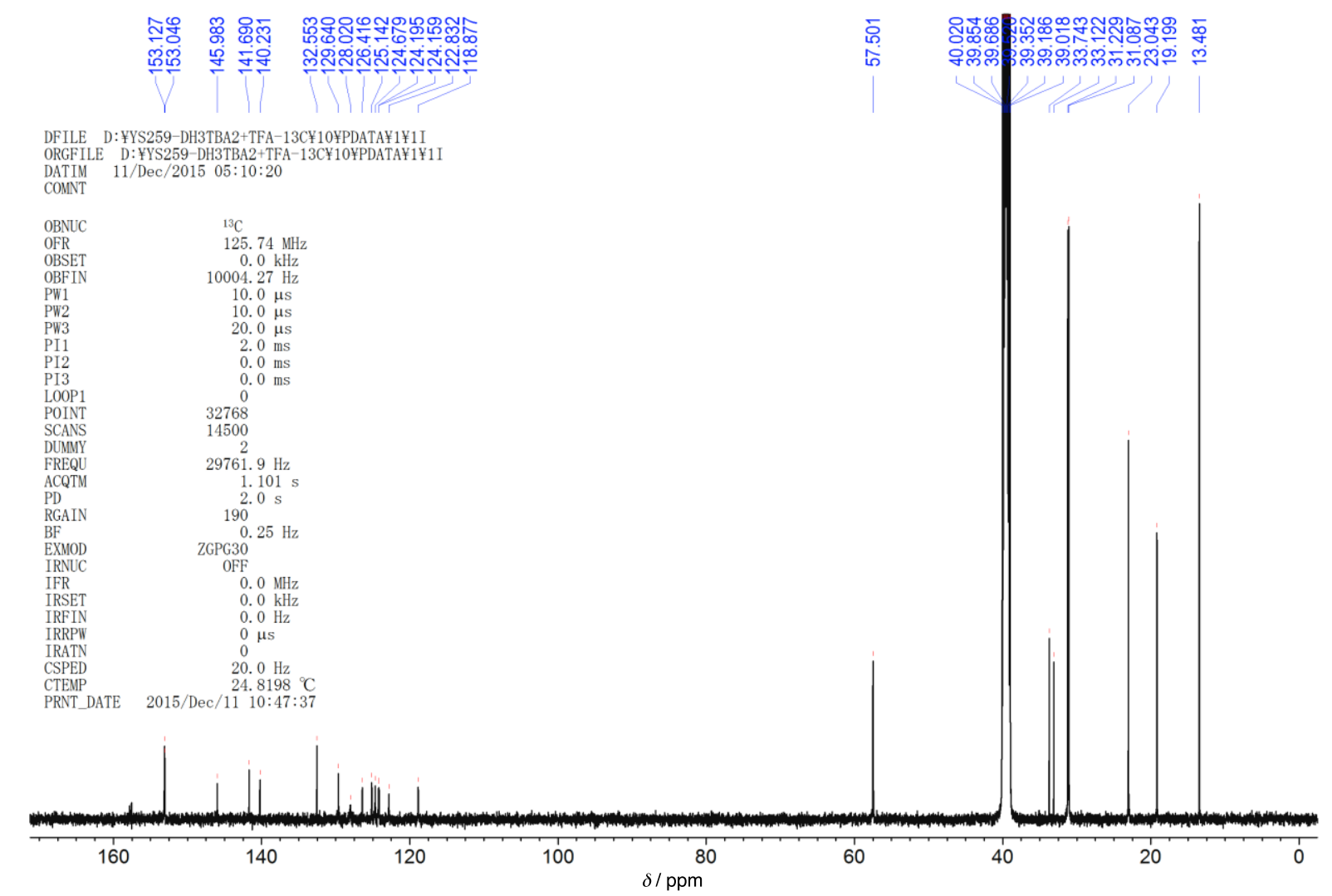

Figure S55. ${ }^{13} \mathrm{C}$ NMR spectrum of DH3 TBA2 with 2 equiv of TFA in DMSO- $d_{6}$ at $25{ }^{\circ} \mathrm{C}$. 


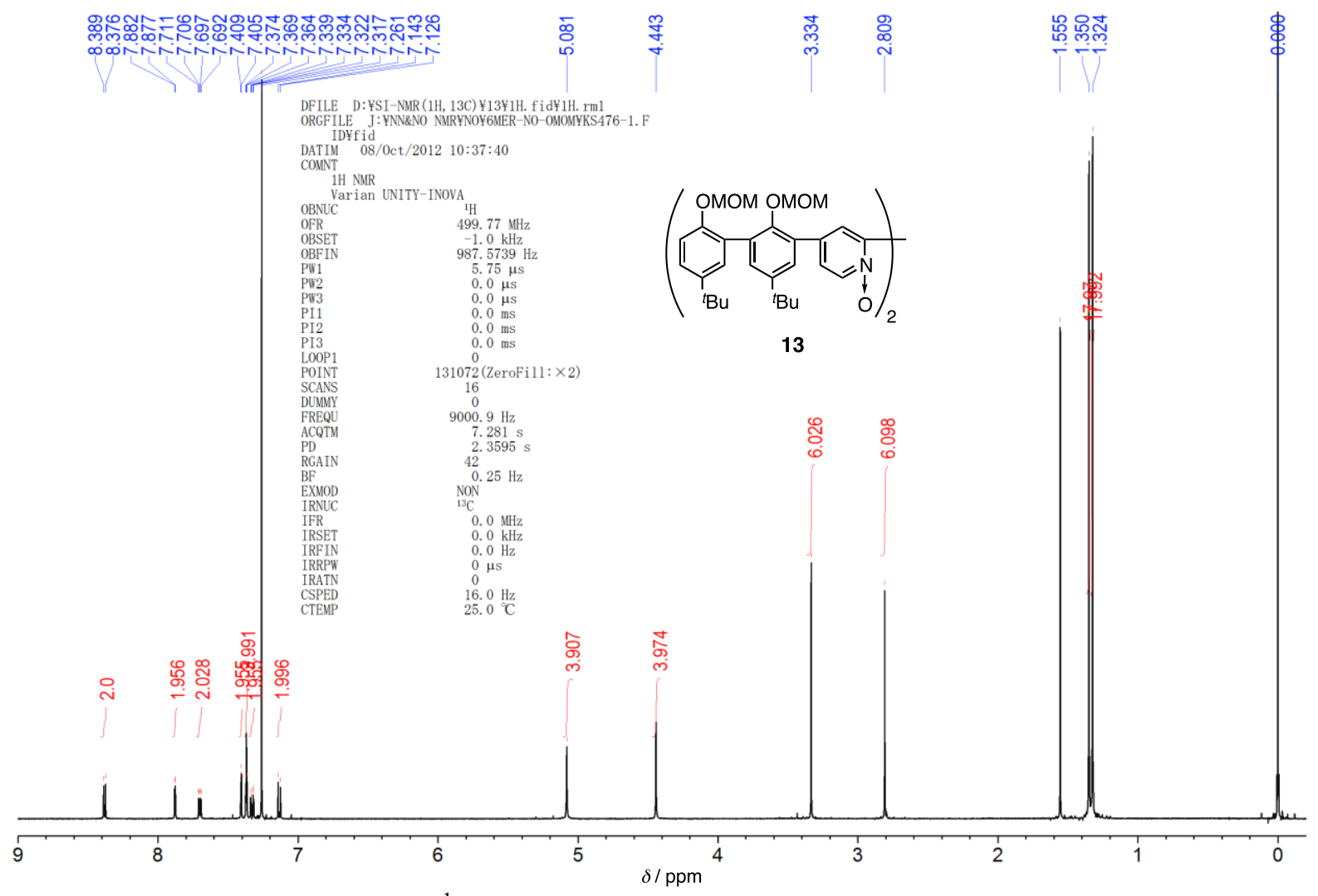

Figure S56. ${ }^{1} \mathrm{H}$ NMR spectrum of 13 in $\mathrm{CDCl}_{3}$ at $25{ }^{\circ} \mathrm{C}$.

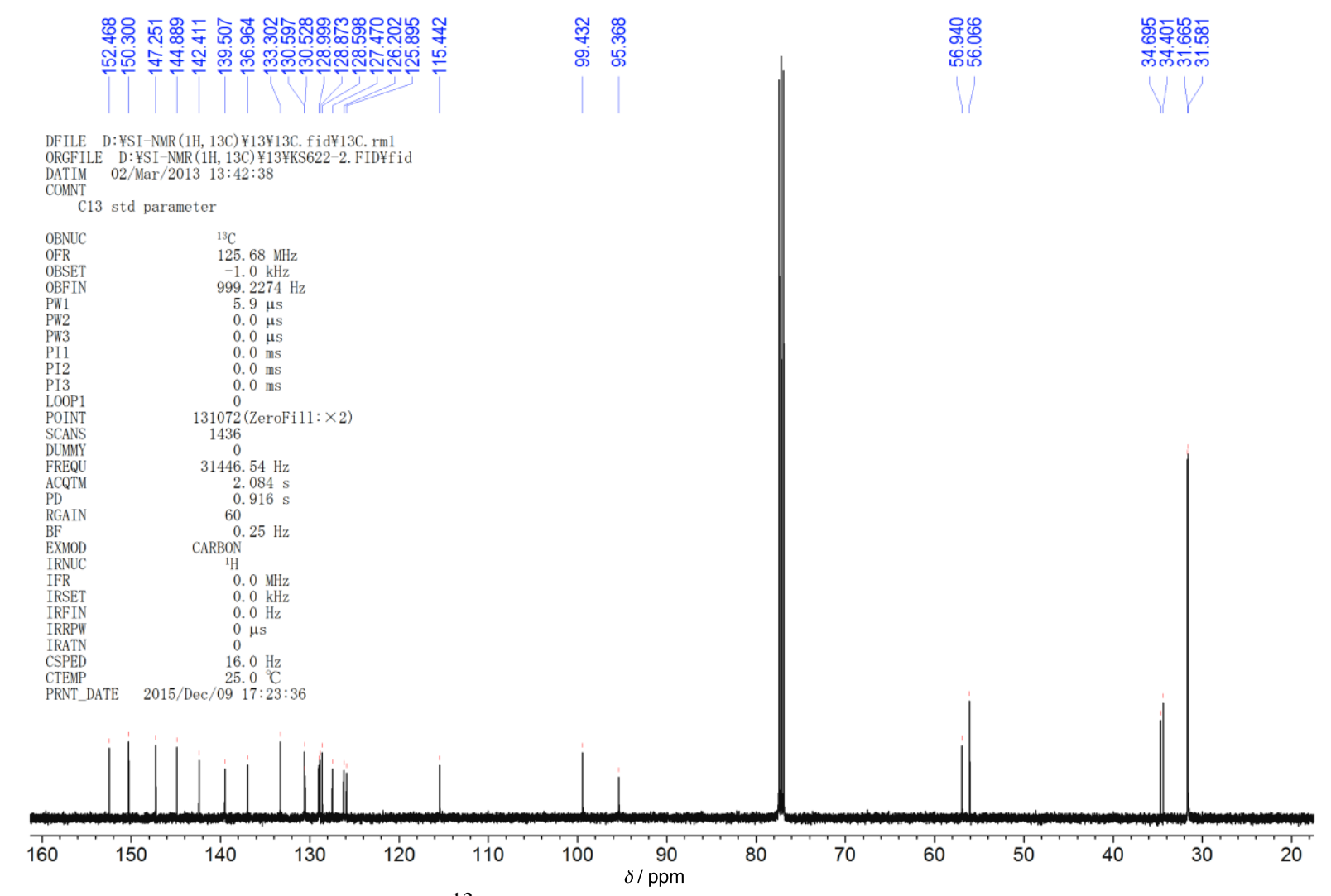

Figure S57. ${ }^{13} \mathrm{C}$ NMR spectrum of 13 in $\mathrm{CDCl}_{3}$ at $25^{\circ} \mathrm{C}$. 


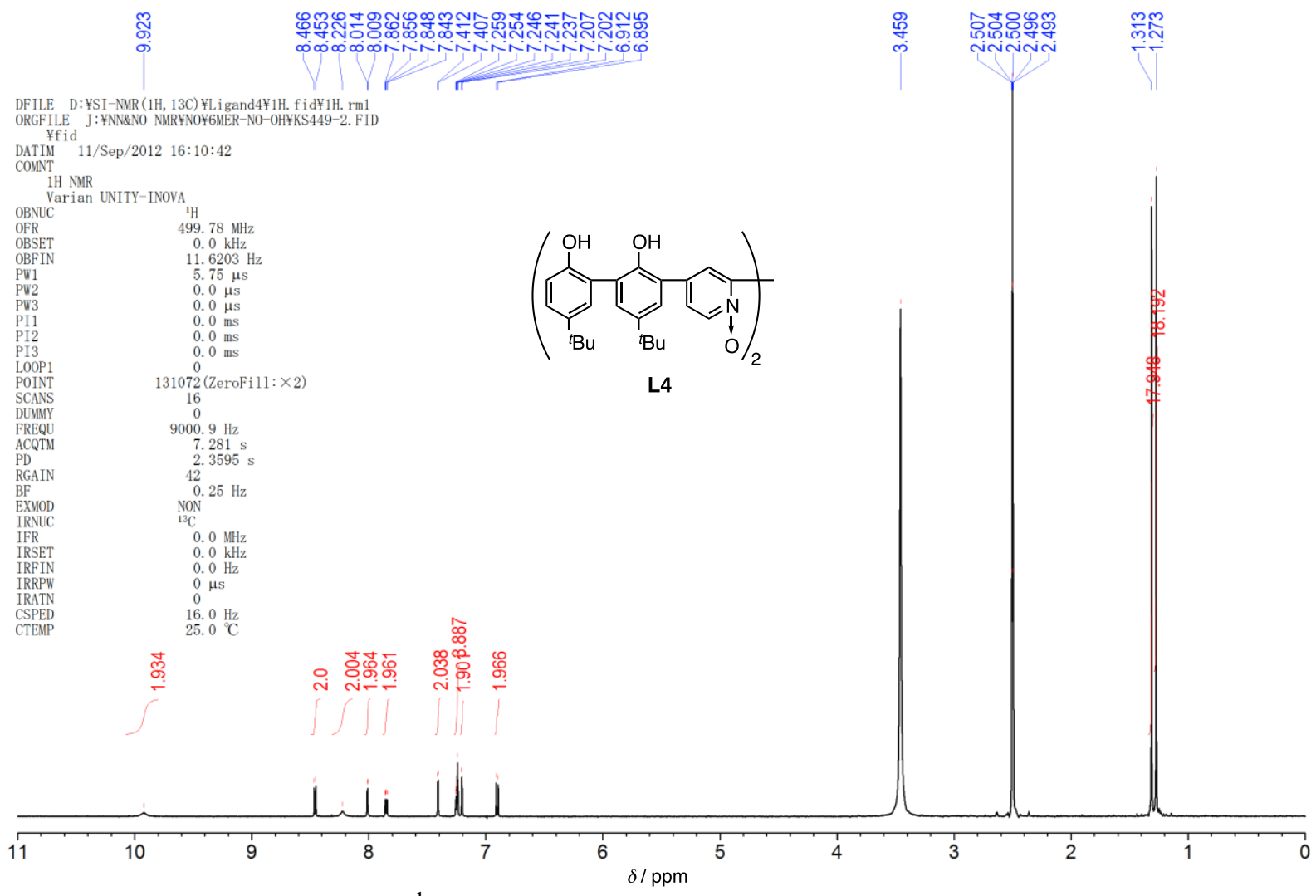

Figure S58. ${ }^{1} \mathrm{H}$ NMR spectrum of $\mathbf{L} 4$ in DMSO- $d_{6}$ at $25^{\circ} \mathrm{C}$.

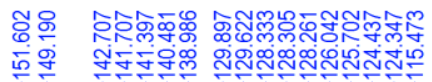

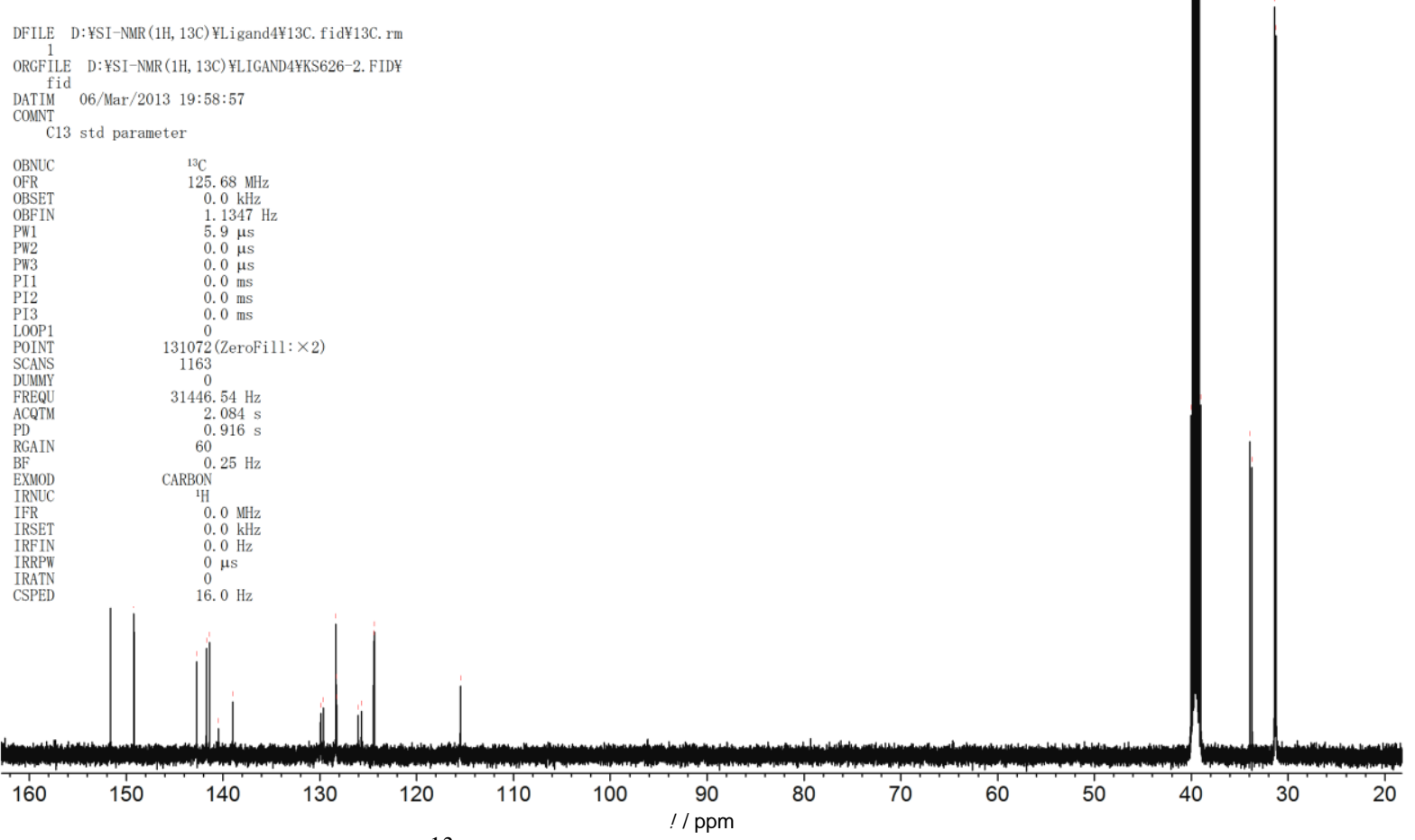

Figure S59. ${ }^{13} \mathrm{C}$ NMR spectrum of $\mathbf{L} 4$ in DMSO- $d_{6}$ at $25{ }^{\circ} \mathrm{C}$. 


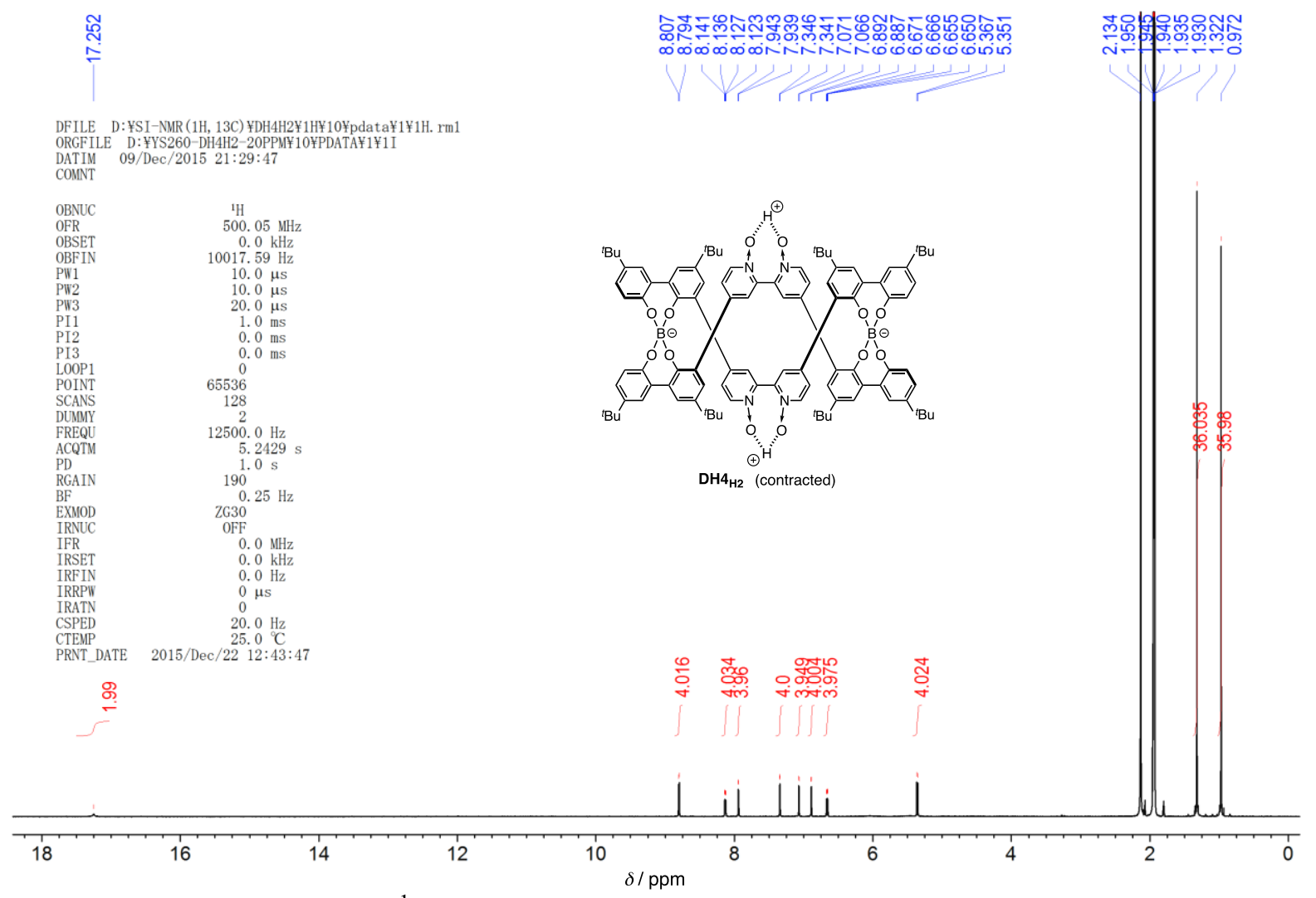

Figure S60. ${ }^{1} \mathrm{H}$ NMR spectrum of $\mathbf{D H} 4_{\mathbf{H} 2}$ in $\mathrm{CD}_{3} \mathrm{CN}$ at $25^{\circ} \mathrm{C}$.

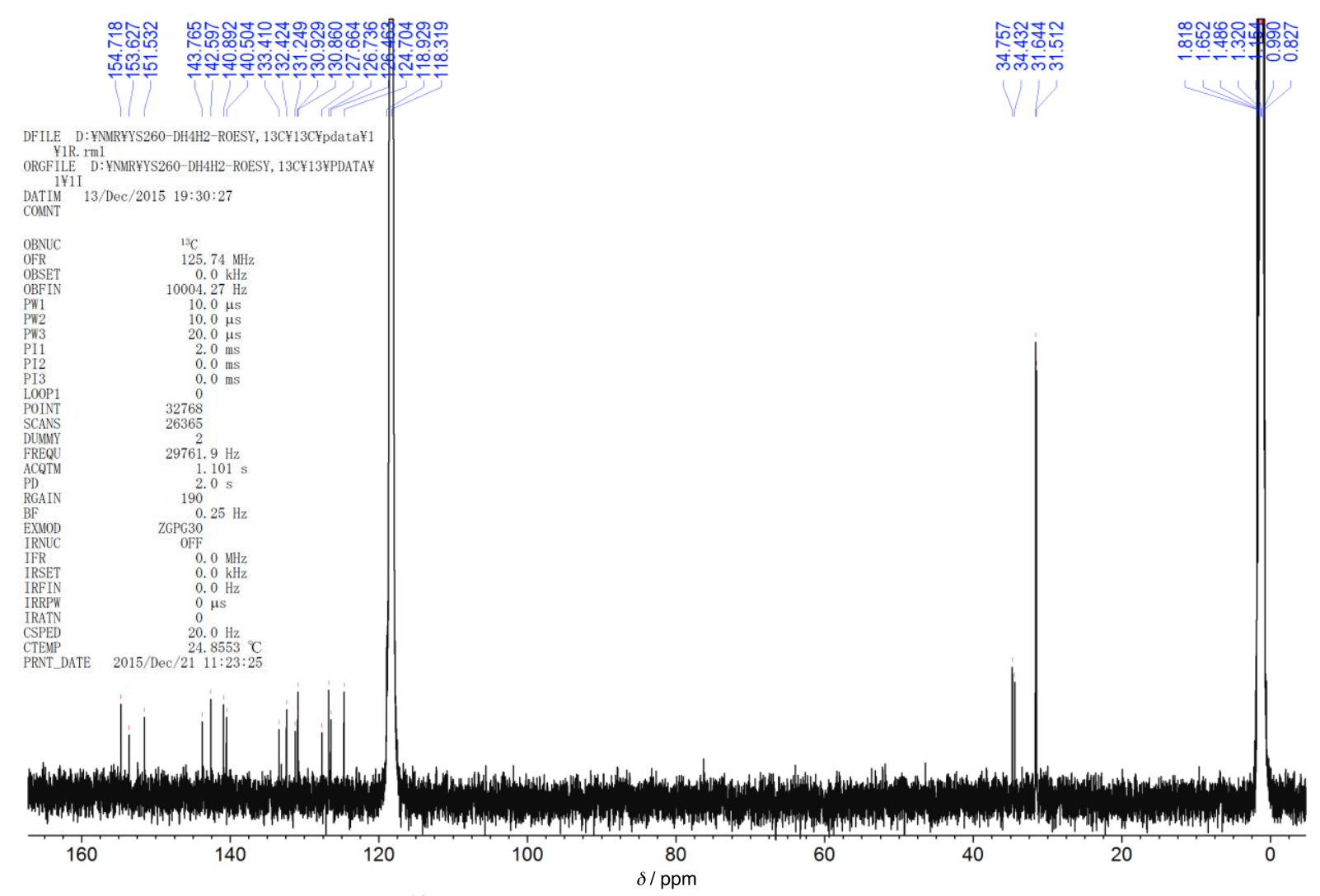

Figure S61. ${ }^{13} \mathrm{C}$ NMR spectrum of $\mathrm{DH}_{4} \mathrm{H}_{2}$ in $\mathrm{CD}_{3} \mathrm{CN}$ at $25^{\circ} \mathrm{C}$. 


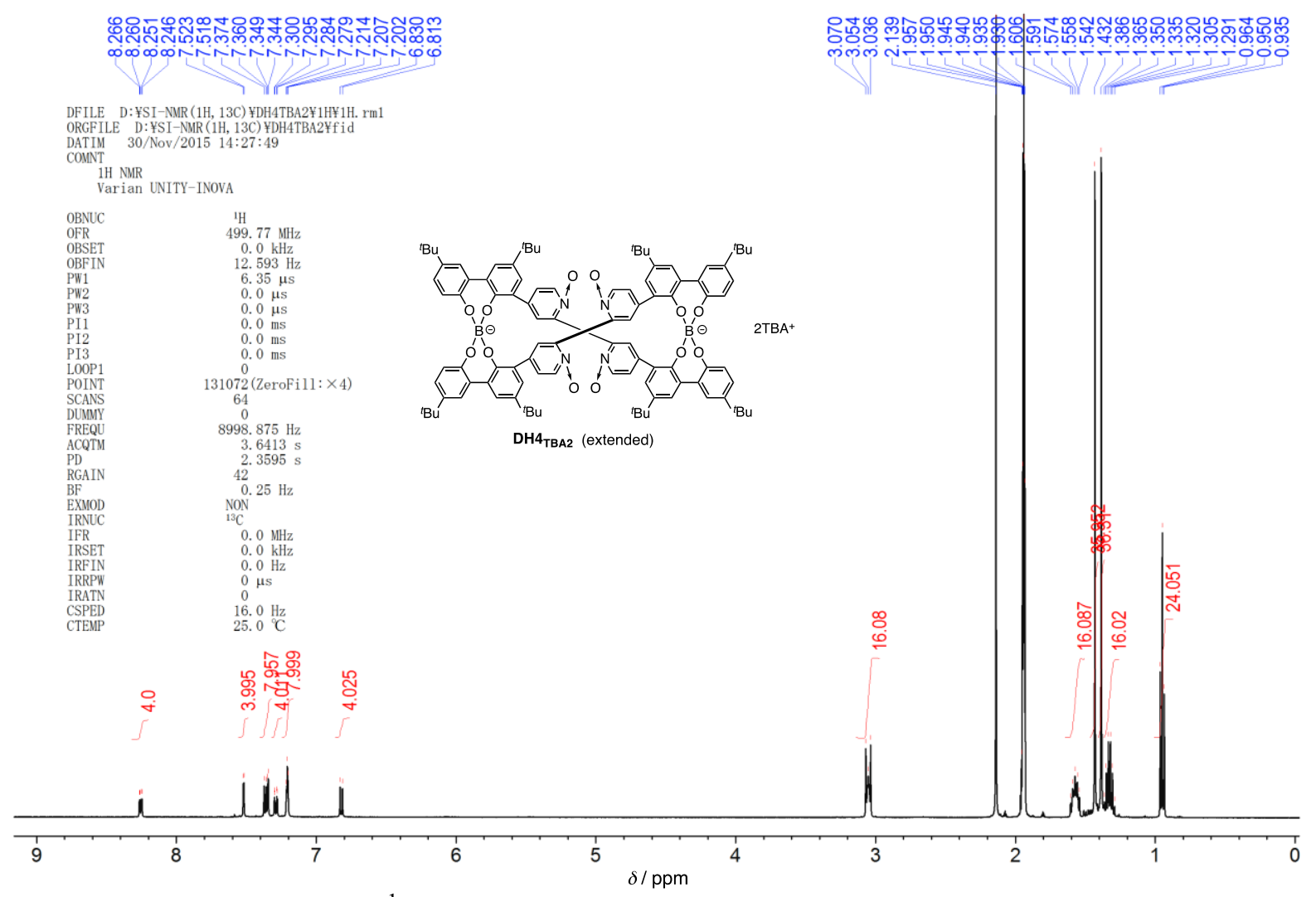

Figure S62. ${ }^{1} \mathrm{H}$ NMR spectrum of DH4 TBa2 in $\mathrm{CD}_{3} \mathrm{CN}$ at $25^{\circ} \mathrm{C}$.

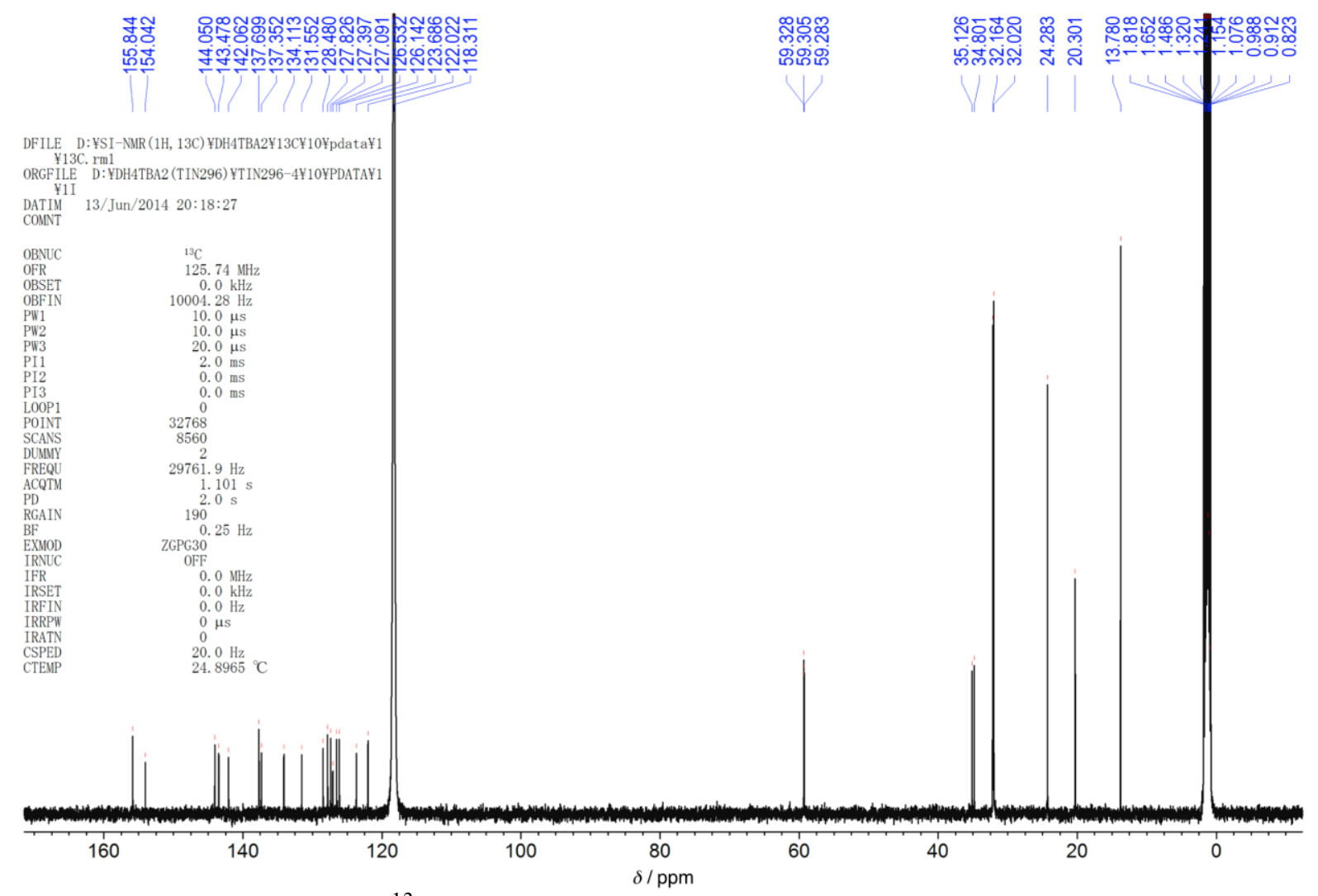

Figure S63. ${ }^{13} \mathrm{C}$ NMR spectrum of DH4 TBA2 in $\mathrm{CD}_{3} \mathrm{CN}$ at $25^{\circ} \mathrm{C}$. 